\title{
La Dimensión Cultural de la Gestión de Asentamientos Humanos Sostenibles en la Era de la Información: Hacia un Ecologismo Mediatizado
}

\author{
Armando Páez. aaopz@yahoo.com Magíster en Antropología y Desarrollo. Universidad de Chile
}

\section{Resumen}

La gestión de asentamientos humanos sostenibles tiene por objetivo, en su dimensión cultural, generar una conciencia ambiental. Esta investigación hace una revisión de las estrategias recomendadas por las Naciones Unidas para dicho fin identificando el papel conferido a los medios de comunicación, ya que en la sociedad de la información los medios 'reinventan' la cultura: reproducen ideologías, construyen sentido, difunden patrones de socialización y crean un nuevo clima cognoscitivo y de aprendizaje. En el capítulo uno se presentan brevemente la historia y valores del movimiento ecologista y algunas características de la sociedad de la información. En el capítulo dos se resumen trabajos antropológicos que han abordado el problema de la sostenibilidad. En el capítulo tres se indica cómo la cultura ha sido afectada por los medios. En el capítulo cuatro se revisa la dimensión cultural de las declaraciones, planes y programas del UNEP y el UNCHS relacionadas con la gestión de asentamientos humanos sostenibles; el análisis expone que las Naciones Unidas no han considerado a profundidad la mediatización de la cultura ya que las instituciones educativas son visualizadas como los órganos centrales en la formación valórica del sujeto, otorgándole a los medios un papel instrumental. En el último capítulo se profundiza en el concepto de imaginario social para plantear que la política cultural ambiental debe basarse en la difusión mediática de un universo simbólico que favorezca la adopción de los valores propuestos por el ecologismo; el desafío es la construcción social de la sostenibilidad: la ideación colectiva de una sociedad ecológica.

Palabras clave: Sostenibilidad, ecologismo, cultura, mediatización, imaginario.

\section{Abstract}

The promotion of sustainable human settlements has as its objective, in its cultural dimension, the generation of environmental awareness. This research examines the strategies recommended by the United Nations (UN) for the purpose of identifying the role conferred on the media. In the informational society media 'reinvent' culture by reproducing ideologies, constructing meaning, diffusing of social patterns and creating a new cognitive learning climate. In chapter one a brief history and the values of the environmental movement are presented, additionally, some characteristics of the informational society are identified. Chapter two summarizes anthropological works that have treated the problems of sustainability. The third chapter exposes how the media has affected culture. Chapter four revises the cultural dimension of declarations, plans and programs of the UNEP and the UNCHS as these relate to sustainable human settlements and their promotion. The analysis suggests that the UN has not deeply considered the mediatization of culture since education institutions continue to be viewed as the principal organs in the values formation of the subject while media serves a secondary instrumental role. The last chapter presents the idea that social imagery be used to propose cultural-environmental policy based in mediatic diffusion of a symbolic universe that favors the adoption of values exposed by environmentalism. The challenge herein defined as the social construction of sustainability and more significantly, the collective ideation of an ecologically sound society.

Key words: Sustainability, environmentalism, culture, mediatization, imagery. 


\title{
1. Introducción
}

\section{La gestión de asentamientos humanos sostenibles}

En su informe Perspectivas del medio ambiente mundial 2000, el Programa de las Naciones Unidas para el Medio Ambiente indicó:

\begin{abstract}
Hasta ahora las principales iniciativas de políticas ambientales se emprendían dentro de un marco temporal prolongado, pero actualmente se ha llegado a la conclusión de que no queda tanto tiempo para una transición racional y bien planificada hacia un sistema sostenible (UNEP, 2000a: 15).
\end{abstract}

El problema de la sostenibilidad no sólo considera aspectos relacionados con el medio natural; además de proteger o 'administrar' correctamente los recursos naturales y de conservar y multiplicar la capacidad productiva de los agrosistemas y sistemas pesqueros, se busca crear asentamientos humanos que ofrezcan buenas condiciones de vida. La sostenibilidad, como nuevo proyecto social global, debe valorarse por sus aspectos cualitativos; quizá es aventurado decir que inaugura una nueva etapa en la historia humana, un período posterior a la posmodernidad, ya que se ha convertido en un nuevo metarrelato basado en una racionalidad que incorpora tanto visiones premodernas como conocimientos científicos (modernos): Pachamama y Biosfera son términos reconocidos.

Muchas de las políticas 'urgentes' que se dictarán en pos de la sostenibilidad afectarán la vida de los habitantes de las zonas urbanas, no sólo porque la mayoría de la población mundial residirá en asentamientos urbanos ${ }^{1}$-convirtiéndose por lo tanto en el escenario de los conflictos sociales- sino porque los actuales modos de vida adoptados en las ciudades provocan un mayor deterioro ambiental $^{2}$ (mayor consumo energético, mayor producción de residuos domésticos, mayor emisión de contaminantes) (Anexo 1). Apunta Enrique Leff:

Nada más insustentable que el hecho urbano. La ciudad ha sido convertida por el capital en el lugar donde se aglomera la producción, se congestiona el consumo, se hacina la población y se degrada la energía. Los procesos urbanos se alimentan de la sobreexplotación de los recursos naturales, la desestructuración del entorno ecológico, el desecamiento de los mantos freáticos, el succionamiento de los recursos hídricos, la saturación del aire y la acumulación de basura. La urbanización que ha acompañado a la acumulación de capital y a la globalización de la economía, se ha convertido en la expresión más clara del contrasentido de la ideología del progreso. Del hecho urbano como generador de necesidades (estilos de vida urbana) se ha pasado a un proceso acumulador de irracionalidades (tráfico, violencia, inseguridad). El proceso de urbanización, concebido como la vía ineluctable del desarrollo humano, es cuestionado por la crisis ambiental que problematiza la naturaleza del fenómeno urbano, su significado, sus funciones y sus condiciones de sustentabilidad (Leff, 1998: 244 y 245).

Las principales causas del deterioro ambiental mundial son las modalidades industriales de producción y consumo (Agenda 21, parágrafo 4.3).

La gestión del desarrollo sostenible de los asentamientos humanos comprende, en términos generales, una serie de recomendaciones (medidas y actividades) cuyo objetivo es lograr que las ciudades y otros asentamientos mejoren sus condiciones de vida (sociales, políticas, económicas,

\footnotetext{
${ }^{1}$ Se estima que para el año 2015 el 53.2 por ciento de la población mundial residirá en centros urbanos (localidades con más de 5000 habitantes); para el año 2030 se calcula que lo hará el 60 por ciento. Todos los países aumentarán su nivel de urbanización -aun los ya urbanizadosActualmente cerca del 50 por ciento de la población mundial vive en zonas urbanas.

${ }^{2}$ Se emplearán en este trabajo indistintamente los términos ambiental y ecológico.
} 
ambientales) y disminuyan su impacto ecológico (contaminación, demanda de recursos, generación de residuos).

El proceso de industrialización-urbanización-degradación ambiental que viene experimentando la humanidad desde mediados del siglo XIX comenzó a problematizarse internacionalmente a finales de la década de 1960. En 1972, en Estocolmo, se celebró la Conferencia de las Naciones Unidas sobre el Medio Humano, primera reunión intergubernamental que propuso medidas concretas buscado revertir la degradación de los centros urbanos, zonas rurales y ecosistemas. En 1976, en Vancouver, la I Conferencia de las Naciones Unidas sobre los Asentamientos Humanos (Hábitat I) profundizó en la situación de las ciudades. Los esfuerzos emprendidos durante las décadas de 1970 y 1980 no fueron suficientes para 'ecologizar' el desarrollo y disminuir la pauperización social (desempleo, marginación, inseguridad). En 1992, promoviendo la nueva noción del desarrollo (el desarrollo sostenible), se organizó en Río de Janeiro la Conferencia de las Naciones Unidas sobre el Medio Ambiente y el Desarrollo (Cumbre de la Tierra) y en 1996, en Estambul, la II Conferencia de las Naciones Unidas sobre los Asentamientos Humanos (Hábitat II).

Los documentos suscritos en estos eventos son, de una u otra manera, la pauta a seguir en la toma de decisiones y elaboración de políticas relacionadas con la promoción de asentamientos humanos seguros, salubres, habitables, equitativos, sostenibles y productivos, ya que sirven de referencia no sólo a los ministerios nacionales y organizaciones internacionales sino a los gobiernos locales, universidades, organizaciones no gubernamentales y comunitarias, institutos de investigación, empresas, agencias de cooperación y fundaciones para el desarrollo y la conservación ambiental. Estos documentos son:

- $\quad$ Plan de Acción para el Medio Humano (1972)

- $\quad$ Plan de Acción para los Asentamientos Humanos (1976)

- $\quad$ Agenda 21 (Programa 21) (1992)

- $\quad$ Plan de Acción Mundial del Programa de Hábitat (1996).

Los logros alcanzados a partir de la Cumbre de la Tierra y Hábitat II fueron evaluados, respectivamente, en 1997 (Río+5) y en 2001 (Estambul+5), suscribiéndose el Programa para continuar con la instrumentación de la Agenda 21 (1997) y la Declaración sobre las ciudades y otros asentamientos humanos en el nuevo milenio (2001). Estos Planes y Programas consideran aspectos económicos, financieros, normativos, políticos, tecnológicos, sociales y culturales. Dentro de la dimensión cultural se valora la diversidad humana y se promueve una conciencia y sensibilidad 'ambiental'. Esto último no ha sido discutido a profundidad. La gestión de asentamientos humanos sostenibles se ha centrado principalmente en aspectos técnicos y normativos, de esta manera se hacen o promueven inversiones en la construcción de plantas de tratamiento de aguas servidas; infraestructura para transportar agua potable; drenaje y alcantarillado; vehículos y tecnologías no petroleras (solares, eólicas, geotérmicas); edificios y viviendas bioclimáticos (ahorradores de energía); pavimentación; reciclaje; proyectos de rescate ambiental (reforestación, restauración de suelos, creación de áreas verdes, descontaminación atmosférica); y se establecen multas e impuestos para orientar el comportamiento de productores y consumidores. Estas medidas disminuirán el impacto de las actividades humanas en la biosfera, pero no garantizan el surgimiento de una sociedad con una cultura ecológica; de hecho, por las actuales dificultades económicas que sufre el mundo, las políticas ambientales son consideradas como un obstáculo al 'desarrollo' (crecimiento económico). El mejoramiento ambiental puede ser pasajero.

La participación social es un factor indispensable para transitar a sociedades sostenibles, ya sea porque la gente se suma a las iniciativas del gobierno o de organizaciones no gubernamentales o internacionales o porque las iniciativas surgen de las propias comunidades. No sólo deben existir condiciones políticas que estimulen la participación sino que ésta debe valorarse en sí misma; más aún, la sostenibilidad debe tener sentido para que la gente se organice y trabaje en su consecución. El mundo apenas parece reaccionar: ideas que integren lo social y lo ambiental vienen exponiéndose desde hace más de treinta años... 


\section{El ecologismo}

La cultura ambiental encuentra sus valores en la ideología del ecologismo. El movimiento ecologista surge en la década de 1960 en la reacción social que provocaron las primeras investigaciones científicas ${ }^{3}$ sobre los efectos de la industrialización y las posibles consecuencias de la sobrepoblación. En abril de 1970 se celebró en Estados Unidos el primer Día de la Tierra. En el Seminario de Founex (1971), expertos sobre desarrollo y medio ambiente analizaron el estado del medio ambiente mundial, este evento sirvió de antecedente a la Conferencia de las Naciones Unidas sobre el Medio Humano. En 1972 el Club de Roma publicó Los limites del crecimiento, informe sobre las tendencias demográficas y ecológicas del mundo (la investigación inició en 1970). Además de las Conferencias de Estocolmo (1972) y Vancouver (1976), en la década de 1970 se efectuó la I Conferencia Intergubernamental sobre Educación Ambiental (Tbilisi, 1977) y se constituyó el Programa de las Naciones Unidas para el Medio Ambiente (a partir de la Conferencia de Estocolmo); esos años el ecodesarrollo sintetizó las demandas de los movimientos populares y ecologistas -no sólo de los países desarrollados - promoviendo procesos productivos basados en la capacidad de los ecosistemas. El ecologismo dejó el discurso moderado o proteccionista profundizando en su crítica al capitalismo acusándolo de autoritario, injusto y explotador del ser humano. En 1987 se publicó el primer informe de la Comisión Mundial sobre Medio Ambiente y Desarrollo (constituida en 1983 por las Naciones Unidas), titulado Nuestro futuro común (conocido también como Informe Brundtland) donde se hizo oficial el discurso de la sostenibilidad al reconocer la degradación ambiental y la creciente pauperización de la humanidad. Dicha Comisión promovió la Cumbre de la Tierra. En la Agenda 21 (1992) y el Programa de Hábitat (1996) se dan elementos para pasar de la denuncia a la acción a nivel internacional, nacional, provincial y local; el desafío es que los más de 250 mil municipios existentes en el mundo diseñen e instrumenten su propia Agenda 21 (Agenda 21 local). En la Declaración de Malmö(2000) (Primer Foro Global Ministerial de Medio Ambiente) se ratifica dicha Agenda advirtiéndose sobre el deterioro ambiental aún existente.

A pesar de los acuerdos suscritos, los gobiernos no han cumplido con sus compromisos y las industrias ignoran las recomendaciones. Ciertamente se interrelacionan diversos factores de tipo estructural que impiden la gestión del desarrollo sostenible, sin embargo, así como sería erróneo desconocer los factores estructurales, ignorar el papel del sujeto en la gestión de la sostenibilidad también sería incorrecto. J. M. Sabucedo, B. Klandermans, M. Rodríguez y M. de Weerd destacan el papel activo de los individuos y grupos en la definición de determinadas situaciones como problemáticas:

De esta manera, se produce un cambio sustancial en la manera de entender la dinámica de la acción política y la protesta. Así, lo importante ya no sería [...] las características personales de los participantes o la existencia de condiciones estructurales adversas, sino la interpretación que los sujetos hiciesen de las mismas. (Sabucedo et al., 1999: 142)

Lo que da sentido y justifica la existencia de los movimientos sociales ${ }^{4}$, indican, es el plantear discursos alternativos sobre la realidad, ya que de esta manera cuestionan situaciones que hasta ese momento no eran problematizadas y/o defienden posiciones contrarias a las creencias

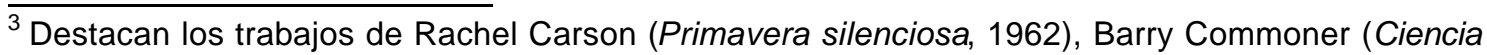
y supervivencia, 1967), Paul R. Ehrlich (La bomba de la población, 1968), Lewis Mumford (Perspectivas urbanas, 1968), Paul R. y Anne H. Ehrlich Población, recursos, medio ambiente, 1970), Max Nicholson (La revolución del medio ambiente, 1970).

${ }^{4} \mathrm{M}$. Diani da la siguiente definición de movimiento social en un intento por sintetizar la teorización actual: "Un movimiento social es una red de interacciones informales entre una pluralidad de individuos, grupos y/u organizaciones, ocupados en un conflicto político o cultural, en base a una identidad colectiva compartida" (Valencia et al., 1999: 207).
} 
dominantes (Sabucedo et al., 1999: 145). Indica Angela Cheater (1989: 238) que las estructuras mentales -ideologías - son anteriores a las relaciones económicas, políticas y sociales.

L. W. Milbrath efectuó un análisis de las creencias, normas y valores fundamentales del ecologismo, contrastándolas con las del paradigma social dominante -cuya creencia nuclear es la dominación:

\section{Paradigma Ecologista}

1. Alta valoración de la naturaleza

a. Amor a la naturaleza por sí misma

b. Vivir en armonía con la naturaleza

c. Protección ambiental por encima del desarrollo económico

2. Interés generalizado por...

a. Otras especies

b. Otros pueblos

c. Otras generaciones

3. Planificación y actuación cuidadosa para evitar riesgos

a. Ciencia y tecnología no siempre son buenas

b. Detener desarrollo de energía nuclear

c. Desarrollo y uso de energía blanda

d. Regulación gubernamental para proteger a la naturaleza y a los humanos

4. Límites al crecimiento

a. Escasez de recursos

b. Explosión demográfica

c. Conservación

5. Sociedad completamente nueva

a. Los humanos dañan seriamente la naturaleza y se dañan a sí mismos

b. Apertura y participación

c. Enfasis en bienes públicos

d. Cooperación

e. Posmaterialismo

f. Estilos de vida simples

g. Enfasis en la satisfacción del trabajo

6. Nueva política

a. Consultiva y participativa

b. Debate entre partidos sobre relación entre humanos y naturaleza (eje ambiental) izquierda)

c. Deseo de usar acción directa

d. Enfasis en la previsión y la planificación

\section{Paradigma Social Dominante}

1. Baja valoración de la naturaleza

a. Naturaleza para producir bienes

b. Dominación humana

c. Crecimiento económico por encima de la protección ambiental

2. Compasión sólo por lo cercano/querido

a. Explotación de otras especies

b. Desinterés por otros pueblos

c. Interés sólo por esta generación

3. Aceptar riesgos para maximizar la riqueza

a. Ciencia y tecnología son una bendición

b. Rápido desarrollo de energía nuclear

c. Enfasis en tecnología dura

d. Desvalorizar la regulación: responsabilidad es individual

4. Ningún límite al crecimiento

a. No escasez de recursos

b. No hay problema de población

c. Producción y consumo

5. Sociedad actual correcta

a. Los humanos no dañan seriamente la naturaleza

b. Jerarquía y eficacia

c. Enfasis en el mercado

d. Competición

e. Materialismo

f. Estilos de vida complejos

g. Enfasis en el trabajo por necesidades económicas

6. Vieja política

a. Determinada por expertos

b. Debate entre partidos sobre la organización de la economía (eje derecha/

c. Oposición a la acción directa

d. Enfasis en control del mercado.

Si bien Milbrath apunta que muchos ecologistas muestran características de ambos paradigmas, el modelo es útil para distinguir las visiones del mundo en juego (Javaloy et al., 1999: 178 y 179). 
F. Javaloy, E. Espell y A. Rodríguez señalan que el ecologismo comparte el componente humanista de los nuevos movimientos sociales (visión global de los problemas, énfasis en la solidaridad, dimensión ética, alta valoración de la naturaleza y exigencia de un cambio social) y que, más aún, puede convertirse en el "eje vertebrador" de su integración ya que plantea una nueva concepción del mundo y un programa de acción que permite una solución a los grandes dilemas que cuestionan la supervivencia de la humanidad (Javaloy et al., 1999: 168, 175 y 176).

Sin embargo, a pesar de haber ganando espacios a nivel civil, periodístico, académico y aun político y empresarial y de ser una ideología integradora, el ecologismo no ha movilizado proactivamente a la mayoría de la población mundial: su influencia no se ve reflejada en la praxis cotidiana de una cantidad importante de gobiernos (nacionales y locales), empresas, organizaciones e individuos y hay personas que lo rechazan abiertamente. Crecimiento económico y democracia no garantizan la gestión del desarrollo sostenible. Más aún, la 'ecologización' de la opinión pública no conlleva al cambio social (ecosocial); apunta Ulrich Beck:

No faltan ideas para modificar la sociedad. Hoy en día (igual que en las revoluciones de siglos pasados) muchos contemporáneos tienen planes para cambiar el mundo alrededor de ellos, que llevan en sus bolsillos o en su corazón [...] Incluso, la demanda por una 'reforma ecológica de la sociedad' sale de los labios de representantes de las industrias riesgosas (sin volverse verdes).

[...] Vivimos en una sociedad de riesgo autocrítica, que continúa, a pesar de restringidas punzadas de consciencia, en las viejas rutinas. Esta coincidencia de una agitación verbal de convicciones revolucionarias y la inacción conservadora puede surgir de una concesión verbal al espíritu de los tiempos. Ella es y seguirá siendo una amenaza sui generis (Beck, 1999: 232 y 233).

Nunca hubo tanta información, debate, planificación, inversión, etc., sobre cuestiones socioambientales, sin embargo, todo parece insuficiente. Esta situación, es, sin duda, una de las grandes paradojas que debe resolver la humanidad. No sólo es una cuestión financiera, tecnológica, de conocimientos, periodística y jurídica, sino antropológica: ¿tiene sentido para el ciudadano común, para el legislador, para el empresario, para el académico, para el juez... la gestión del desarrollo sostenible de los asentamientos humanos?

\section{La era de la información}

Escuelas y universidades han sido tradicionalmente las encargadas de reproducir las ideologías, pero este papel las últimas décadas ha sido desempeñado también por los medios de comunicación, de hecho, han superado a las instituciones educativas (Van Dijk, 1999). Junto con la urbanización y el deterioro ambiental, la mediatización (proceso de articulación del funcionamiento de las instituciones sociales con los medios de comunicación) es otro fenómeno definidor de nuestra época histórica. Los medios ocupan un papel central en la conformación cultural de la sociedad contemporánea, ya que además de reproducir ideologías, construyen sentido (Sodré, 1998), participan en el proceso de socialización (Ball-Rokeach y De Fleur, 1994) y crean un nuevo clima cognoscitivo y de aprendizaje (Pérez, 2000). Sodré habla de una 'reinvención' cultural.

Jordi Borja y Manuel Castells indican que las ciudades y sociedades de todo el mundo están experimentando una profunda transformación histórica estructural. En el centro de esta transformación se halla una revolución tecnológica, organizada en torno a las tecnologías de información:

Basándose en la nueva infraestructura tecnológica, el proceso de globalización de la economía y la comunicación ha cambiado nuestras formas de producir, consumir, gestionar, informar y pensar. No toda la actividad económica o cultural en el mundo es global. En realidad, la inmensa mayoría de dicha actividad, en proporción de personas participantes, es de ámbito local o regional. Pero las 
actividades estratégicas dominantes, en todos los planos, están organizadas en redes globales de decisión e intercambio, desde los mercados financieros a los mensajes audiovisuales. El planeta es asimétricamente interdependiente y esa interde pendencia se articula cotidianamente en tiempo real, a través de las nuevas tecnologías de información y comunicación, en un fenómeno históricamente nuevo que abre de hecho una nueva era de la historia de la humanidad: la era de la información (Borja y Castells, 1997: 21).

Señalan que la era de las telecomunicaciones no diluye los centros urbanos, sino que al permitir la gestión y la comunicación entre sí de sistemas urbanos y rurales distantes tiende a concentrar la población en aglomeraciones territoriales, parcialmente discontinuas, de gigantesca dimensión y de características socio-espaciales históricamente nuevas:

La gestión de dichas ciudades y la construcción de nuevos modelos de vida capaces de responder a las nuevas formas productivas y culturales plantea enormes desafíos. No sólo por la acumulación de problemas funcionales, sociales y medio ambientales en los asenta-mientos humanos de nuevo tipo, sino porque nos encontramos ante procesos de transformación escasamente entendidos (Borja y Castells, 1997: 22).

Subrayan que la cultura en la sociedad de la información está organizada en torno al sistema audiovisual. Pero en los últimos años un fenómeno de mayor alcance se ha producido: la creciente digitalización de todos los mensajes, audiovisuales, impresos, interpersonales, que forman un hipertexto globalizado e interactivo.

Ello permite el paso de los actuales medios de comunicación de masas a medios de comunicación individualizados, segmentados, focalizados a audiencias específicas, aunque su producción y control tecnológico y financiero siga teniendo características globales. No vivimos en una aldea global, sino en chalecitos individuales más o menos adosados, globalmente producidos y distribuidos. Junto a ello, el extraordinario desarrollo de Internet está multiplicando las fuentes de información e intercambio horizontal, aunque todavía restringido a una elite mundial. Lo más relevante, por el momento, es que la amplitud y flexibilidad del nuevo sistema de comunicación ha aumentado su capacidad de absorción de todo tipo de expresiones culturales, sociales y políticas, en un universo digital electrónicamente comunicado y difundido (Borja y Castells, 1997: 28 y 29).

\section{Problema de investigación}

Jesús Martín Barbero indica que "muchos" documentos de la Organización de las Naciones Unidas para la Educación, la Ciencia y la Cultura $\left(\right.$ UNESCO $^{5}$ ) no contemplan la tecnicidad mediática como dimensión estratégica de la cultura, le confieren a los medios y tecnologías de comunicación un papel instrumental (Martín, 2000: 27). Si bien Martín Barbero no señala los textos de la UNESCO en cuestión, su crítica invita a revisar los documentos sobre medio ambiente y asentamientos humanos antes mencionados ya que también fueron redactados por expertos de las Naciones Unidas, en este caso por el Programa de las Naciones Unidas para el Medio Ambiente $\left(\mathrm{UNEP}^{6}\right.$ ) y el Centro de las Naciones Unidas para Asentamientos Humanos (UNCHS ${ }^{7}$ ). Es necesario, dada la relevancia de la gestión de asentamientos humanos sostenibles, identificar si se considera la mediatización en la dimensión cultural de los Planes y Programas diseñados específicamente para ello, ya que los medios -masivos e individualizados- transmiten y también generan imaginarios y significados (modelos) que influyen cotidianamente en los estilos de vida de la gente. La cultura 'ecológica' será mediatizada o no será. Subrayan Borja y Castells:

\footnotetext{
${ }^{5}$ UNESCO: United Nations Education, Science and Culture Organization.

${ }^{6}$ UNEP: United Nations Environment Programme.

${ }^{7}$ UNCHS: United Nations Centre for Human Settlements.
} 
Puesto que la cultura es un sistema de comunicación y que nuestra sociedad está cada vez más organizada en torno a la producción, distribución y manipulación de símbolos, el espacio político ha sido capturado, en lo esencial, en el espacio de los medios de comunicación. No es que la política sólo opere en bs medios de comunicación, pero sí que, en las sociedades democráticas al menos, el proceso político se decide, esencialmente, en los medios de comunicación. Ello quiere decir que el nivel simbólico de la política es más importante que nunca y que, por tanto, los mensajes deben, ante todo, generar símbolos capaces de recibir apoyo, anclados en personalidades creíbles, fiables y, si es posible, carismáticas. Por duro que sea aceptar este hecho para los intelectuales, no son los programas políticos los que deciden la política. Y por injusto que sea para los gestores, una buena gestión no garantiza el respaldo popular. La política de la sociedad de la información es comunicación simbólica expresada conflictualmente en el espacio mediático (Borja y Castells, 1997: 29).

Indica Sergio Martinic: "Todo proyecto social es una hipótesis de intervención sobre la realidad y, como tal, se sustenta en una teoría o en un conjunto de supuestos y afirmaciones que dan coherencia a la propuesta realizada" (Martinic, 1997: 23). Los Planes y Programas promovidos por las Naciones Unidas son macroproyectos aplicados a nivel mundial. Agrega Martinic que el fracaso de un programa o proyecto social puede deberse a: 1) falla en la factibilidad (condiciones adversas del entorno institucional y/o social); 2) falla en el diseño operativo (no se realizan todas las actividades previstas); 3) falla en la teoría (hipótesis planteadas -relaciones propuestasincorrectas) (Martinic, 1997: 118). No sólo es necesario revisar los supuestos e hipótesis que estructuran las propuestas, sino la misma visión de la 'realidad' que tiene el equipo planificador. Katy Gardner y David Lewis (1996) apuntan que la antropología del desarrollo debe cuestionar las suposiciones del desarrollo. Por su parte Kay Milton (1997) indica que la antropología para superar el nivel técnico debe aplicar "la duda sistémica" tanto a los modos de identificar problemas y soluciones como a las premisas fundamentales que constituyen la base desde donde problemas y soluciones se identifican como tales. ¿Las estrategias propuestas por el UNEP y el UNCHS para formar una conciencia y sensibilidad 'ambiental' (una cultura ambiental o ecológica) contemplan la tecnicidad mediática como dimensión estratégica de la cultura?

\section{Objetivo y metodología}

El objetivo de esta investigación es identificar el papel conferido a los medios de comunicación en la dimensión cultural de los Planes y Programas diseñados por las Naciones Unidas para gestionar el desarrollo sostenible de los asentamientos humanos, a saber:

Plan de Acción para el Medio Humano (1972)

Plan de Acción para los Asentamientos Humanos (1976)

Agenda 21 (1992)

Plan de Acción Mundial del Programa de Hábitat (1996)

Programa para Continuar con la Instrumentación de la Agenda 21 (1997)

- Declaración sobre las Ciudades y Otros Asentamientos Humanos en el Nuevo Milenio (2001).

La revisión documental (análisis de contenido) se hará poniendo especial atención a la dimensión social y cultural de los Planes y Programas, específicamente, a lo mencionado sobre promoción de la creación de una conciencia, sensibilidad, cultura, etc., ambiental.

Como análisis complementario se revisarán las Declaraciones suscritas en las Conferencias de las Naciones Unidas mencionadas:

- Declaración de Estocolmo sobre el Medio Humano (1972)

- Declaración de Vancouver sobre los Asentamientos Humanos (1976)

- Declaración de Río sobre el Medio Ambiente y el Desarrollo (1992) 
- Declaración de Estambul sobre los Asentamientos Humanos (1996).

\section{Antecedentes}

\section{Ciencia y desarrollo sostenible}

La gestión del desarrollo sostenible acontece en un momento histórico en que la 'objetividad' científica es cuestionada. Señala Esther Díaz que en la actualidad la tecnología (informática, ingeniería genética, fisión del átomo, medios masivos de comunicación) ha ocupado el lugar de verdad-poder que hasta mediados del siglo XIX ocupaba la ciencia, entendida como búsqueda del conocimiento por el conocimiento mismo. En nuestros días, la era de la posciencia, la mayoría de las investigaciones se realiza en función de su aplicación a la realidad, esto es, de la tecnología:

El volumen histórico, que ayer nomás ocupaba la ciencia moderna, es ocupado hoy por la posciencia. Es decir, por un conocimiento sólido dependiente de la técnica y potenciado a la vez por ella. La invención de la informática -que nació como tecnología da cuenta de un cambio epistémico fundamental. E conocimiento, hoy, no necesita validarse a partir de un metadiscurso (por ejemplo, el kantiano, en la modernidad) para reafirmarse cognoscitiva y socialmente. Se valida, más bien, a partir de su eficacia. Sin olvidar que la eficacia se mide con parámetros económicos establecidos por quienes manejan las leyes; pero no tanto las leyes jurídicas, morales o científicas sino más bien las leyes del mercado multinacional (Díaz, 2000: 35 y 36).

El ecologismo ha criticado el papel de la ciencia y, lo más importante, lo ha redefinido. Silvio Funtowicz y Bruna de Marchi indican que la relación entre los avances acaecidos en la ciencia y las tecnologías científicas, por un lado, y el desarrollo sostenible, por otro, es compleja, ambigua y presenta múltiples facetas, ya que el simple reconocimiento de los límites ecológicos en términos de producción y consumo económicamente sostenibles conlleva que 'más output' no es lo mismo que 'buen output: "No necesariamente más conocimiento científico, expresado en términos de innovaciones tecnológicas, tendrá como resultado una sociedad más sostenible" (Funtowicz y De Marchi, 2000: 56).

Plantean si la ciencia puede contribuir efectivamente al desarrollo sostenible, ya que los problemas de la sostenibilidad incluyen aspectos complejos y difíciles, "aquellos en los que nuestro conocimiento está fuertemente afectado por la incertidumbre, la ignorancia y el conflicto de valores". En este nuevo contexto, el objeto del ámbito científico "sería impulsar el proceso de resolución social de problemas, incluyendo la participación y el aprendizaje mutuo entre los agentes involucrados, en vez de la búsqueda de 'soluciones' definitivas o impuestas" (Funtowicz y De Marchi, 2000: 57).

Los supuestos básicos de la ciencia moderna deben modificarse para poder desarrollar una ciencia nueva, dirigida a los problemas de la sostenibilidad:

En la ciencia posnormal, el principio organizador no es la Verdad sino la Calidad. La tarea no es ya la de expertos individuales que descubren 'hechos verdaderos' para sustentar 'buenas políticas'; más bien se trata de una tarea que recae en una comunidad extendida, que evalúa y gestiona la calidad de los inputs científicos, en procesos complejos de toma de decisiones donde los objetivos son negociados desde perspectivas y valores en conflicto. Necesitamos todavía una ciencia tradicional y una tecnología de buena calidad, pero sus productos deben ser incorporados en un proceso social integrador. De esta manera, el sistema científico se convertirá en un input útil para nuevas formas de decisión política y de gobernabilidad (Funtowicz y De Marchi, 2000: 59 y 60). 


\title{
Ciencias sociales y desarrollo sostenible
}

E. Leff indica que las ciencias sociales son tal vez las más resistentes a internalizar el saber ambiental

\begin{abstract}
ya que allí se han incorporado los paradigmas teóricos que, partiendo de una filosofía natural y una praxeología mecanicista, cristalizaron en los principios del derecho privado, del contrato social, la racionalidad económica y una razón tecnológica, legitimando las estructuras de poder, los arreglos institucionales y la organización productiva que conformaron la racionalidad social contra natura de la civilización moderna (Leff, 1998: 182).
\end{abstract}

Añade que la construcción de una racionalidad ambiental (nuevas formas de organización social y productiva, valores culturales, formas de significación y relaciones de poder) impone la transformación de las disciplinas sociales que explican los procesos ideológicos y el comportamiento de los actores sociales que participan en estos procesos (Leff, 1998: 182). "El ambiente constituye un campo de externalidad y complementariedad de las ciencias". (Leff, 1998: 135). En efecto, el ambiente, y de manera más amplia el problema de la sostenibilidad, vendrían a ser lo que Mattei Dogan (1997) denomina un 'nuevo ámbito' de conocimiento o un campo híbrido de especialidades (de diferentes disciplinas) en donde se recombinan los saberes y surgen nuevos:

\begin{abstract}
Desde mediados del siglo XIX, la historia de la ciencia es, ante todo, una descripción de la multiplicación de subdisciplinas y de nuevas ramas del saber. Cualquier libro consagrado a la historia contemporánea de la ciencia demuestra cómo el camino real del progreso científico es la especialización híbrida. La mayoría de los especialistas no se asientan en el denominado núcleo de la disciplina, sino en anillos exteriores, en contacto con especialistas de otras disciplinas. Prestan y toman prestados conceptos y términos en las fronteras. Son investigadores híbridos. Disminuye velozmente el número de 'generalistas'. Todo el mundo tiende a especializarse en uno o varios ámbitos de estudio.
\end{abstract}

Leff destaca los aportes que se han desprendido desde la economía, la antropología, la geografía, el derecho y la sociología (Leff, 1998: 135 a 141).

Sylvain Allemand (2000) distingue dentro de las ciencias sociales dos líneas de trabajo relacionadas con el desarrollo sostenible, por una parte los comentarios críticos a esta noción y por otra los trabajos que pretenden darle un contenido concreto. En esta última línea, se intenta aplicar el principio de sostenibilidad a dominios precisos, siendo uno de ellos la ciudad, donde han surgido trabajos sobre la gestión urbana sostenible y programas universitarios y de organizaciones internacionales que proponen mejorar la administración de las grandes ciudades. Señala que la introducción de la problemática del desarrollo sostenible en las ciencias sociales ha producido muchos intentos de modelización, los cuales han aportado otros planteamientos y sobre todo el enfoque sistémico priorizando la interdependencia de las dimensiones económicas, sociales y ambientales.

\section{Antropología y desarrollo sostenible}

La antropología ha comenzado a estudiar la problemática de la sostenibilidad. La antropología ecológica en su análisis de las interacciones cultura/ambiente (adaptación, resiliencia, significación), la antropología del desarrollo al rescatar racionalidades diferentes a la capitalista y criticar el discurso del desarrollo, y la antropología urbana en su lectura de la dinámica del proceso de construcción cognitiva del hecho urbano aportan elementos teóricos y metodológicos al estudio y gestión de la sostenibilidad -coinciden en el registro de casos en donde la sociedad civil se moviliza para proteger, mejorar o manejar su ambiente, enriqueciendo de esta manera la reflexión 
de la ecología política. A continuación se exponen brevemente algunas nociones surgidas de estas áreas de estudio.

Dentro de la antropología ecológica destaca la obra de Roy A. Rappaport. Si bien han pasado más de treinta años de la publicación de su ensayo Naturaleza, cultura y antropología ecológica (1971), su contenido aporta elementos a la reflexión actual sobre el problema de la sostenibilidad. Podemos considerarlo como uno de los primeros textos que analiza bajo una perspectiva antropológica este tema (el proceso de industrialización que observó en Estados Unidos durante la década de 1960 se presenta actualmente en casi todos los países del mundo -los afecta a todos).

Indica que los seres humanos contemplan la naturaleza a través de una "pantalla" compuesta de creencias, conocimientos, conceptos, propósitos y deseos. Estas imágenes culturales (ideología) que han sido transmitidas por los ancestros $u$ otras sociedades o inventadas, determinan sus acciones. Un problema crítico para la humanidad es la discrepancia entre estas imágenes (modelo percibido) y la organización real de la naturaleza (modelo operativo). El desafío consiste, señala en que las sociedades amplíen su conocimiento del medio ambiente (Rappaport, 1975: 271-272). El principal papel de la cultura, considera, es asegurar la supervivencia y el bienestar de los grupos humanos en medios particulares; para lograr esto las sociedades incrementan su organización (adelanto) o producen cambios en ella (adaptación) (Rappaport, 1975: 287). Una buena adaptación cultural permite la evolución general; una mala adaptación conduce, paulatinamente, a la muerte.

El mismo proceso de organizarse para mantenerse bajo un conjunto particular de condiciones ambientales puede disminuir la habilidad de una población para cambiar su organización bajo la presión de condiciones cambiantes, y lo que llamamos avances evolutivos puede resolver viejos problemas creando nuevos (Rappaport, 1975: 288).

Las adaptaciones culturales, como todas las adaptaciones, pueden tener resultados contraproducentes al disminuir en vez de aumentar las posibilidades de supervivencia de los grupos que las practiquen. Una mala adaptación cultural se presenta cuando ésta sirve a sus propios componentes (vgr., instituciones económicas o políticas) a expensas de los seres humanos y los ecosistemas (Rappaport, 1975: 274).

Rappaport expone el proceso mediante el cual el Estado eventualmente termina sirviendo a los intereses de las empresas industriales en detrimento de la protección ambiental; sintetizando su análisis:

1. Los objetivos de producción señalados por autoridades sup ralocales están más expuestos a exceder la capacidad de los sistemas ecológicos locales o de acuerdo con requerimientos locales. La posibilidad de esa violación aumenta con el incremento de la profundidad y complejidad de las estructuras administrativas o económicas, porque al mismo tiempo aumenta la posibilidad de distorsiones, errores y tardanzas en la comunicación de informaciones relativas a condiciones ambientales o de otro tipo, en respuesta a las cuales se toman las decisiones reguladoras.

2. Cuando las funciones reguladoras recaen en personas particulares (burócratas, gerentes o administradores) aumenta la posibilidad de desviaciones de las operaciones reguladoras. El objetivo de la regulación puede no ser ya el bienestar del hombre y la preservación de los ecosistemas, sino que puede convertirse en la preservación de instituciones particulares políticas, sociales o económicas, tal vez a expensas de los sistemas vivientes.

3. Cuando llegan a ser poderosos, los grupos particulares con funciones especiales, como las firmas industriales o industrias determinadas (para las cuales los ecosistemas no son otra cosa que fuentes de materia prima y 
depósitos de desperdicios), tienen una tendencia a capturar o intentar capturar a las agencias que las regulan, y a elevar sus propios propósitos a posiciones preeminentes en los grandes sistemas vivientes de los cuales ellos son sólo una parte.

4. El propósito de las modernas empresas industriales es simplemente perpetuarse a sí mismas. En el fondo no son sino máquinas y la perpetuación de las empresas industriales requiere que mantengan funcionando sus máquinas.

5. Debido a que su maquinaria representa enormes inversiones, y porque emplea a un número considerable de individuos, las empresas industriales han llegado a ser fundamentales en la economía del mundo moderno. Como tales, su perpetuación llega a ser la preocupación más compulsiva del Estado contemporáneo. De este modo, las agencias reguladoras llegan eventualmente a servir a los intereses de las industrias (Rappaport, 1975: 288 y 289).

Para Rappaport el incremento de la industrialización, bajo una perspectiva ecológica -asignando un significado biológico-, sugiere que algunos aspectos de lo que se ha llamado 'progreso' (desarrollo) son patológicos. (Rappaport, 1975: 289 y 290). Cuestiona si el Estado, la ciencia y la tecnología mecanizada, como formas de civilización, son a la larga buenas formas adaptativas. A partir de su estudio de los maring de Nueva Guinea, realizado entre 1962 y 1963, concluyó que las representaciones de la naturaleza que ofrece la ciencia no son más adaptables o funcionales que aquellas imágenes del mundo que guían las acciones de los pueblos 'primitivos' -habitado por espíritus respetados-, ya que al envolver la naturaleza en velos sobrenaturales le brindan cierta protección contra la destructividad y estrechez de miras propias de los humanos: "A la luz de nuestras anteriores observaciones puede sugerirse que es más adaptativo santificar a la naturaleza que a la cultura" (Rappaport, 1975: 287).

Hebe M. C. Vessuri ha definido una agenda de problemas de investigación para la antropología ecológica ${ }^{8}$ relacionados con la sostenibilidad:

- la organización social de la producción

- las consecuencias ambientales de los diferentes estilos de desarrollo

- el conocimiento del uso de recursos desaprovechados y su posible redescubrimiento por los modernos sistemas de investigación y desarrollo

- los mecanismos culturales de la innovación tecnológica

- la recuperación de las prácticas tradicionales de uso múltiple, integrado y sostenido de los recursos

- la formación de valores

- la asimilación de nuevas tecnologías y otros cambios a los valores culturales y la organización social

- $\quad$ las imágenes del mundo natural y el control social (Vessuri, 1994: 191 a 208).

Indica que es imperativo para la investigación reconocer que los acontecimientos y condiciones en el nivel micro de los individuos y grupos domésticos y en el nivel intermedio de las comunidades son fuertemente afectados por fuerzas económicas y políticas en el nivel macro de procesos políticos y económicos regionales, nacionales e internacionales (Vessuri, 1994: 190). En esta postura coincide con Conrad P. Kottak (1999), en lo que éste ha llamado una 'nueva' antropología ecológica.

Sobre la formación de nuevos valores o la recuperación de otros no tan nuevos pero que se perdieron con el avance de la cultura de la modernidad, señala que esto es posible cuando se asume la conciencia de ser miembros de una misma especie biológica y se reconoce la presencia

\footnotetext{
${ }^{8}$ En su ensayo, Vessuri se refiere a la antropología ecológica como ambiental.
} 
del fenómeno aultural en todas partes, en sus múltiples manifestaciones específicas (Vessuri, 1994: 205).

Apunta que los valores y las creencias implícitas en las prácticas tradicionales de diferentes culturas no sólo permiten la conservación de la naturaleza, sino que se revelan como formas eficaces de control social a través de la utilización simbólica de elementos de la dimensión ambiental: "Todas las poluciones misteriosas son peligrosas, pero no debemos descuidar el razonamiento que las vincula a un tipo particular de transgresión: si los niños se mueren, debe haber habido adulterio; si las vacas mueren, deben haberse violado tabúes alimenticios". La idea de castigo sobrenatural como consecuencia de una transgresión moral también aparece en las sociedades industriales modernas: para algunos grupos el sida es consecuencia de la inmoralidad y la violación de normas de conducta sexual. El mal sufrido siempre se adjudica a alguien: es necesario señalar responsables. Señala que el movimiento ecologista/ambiental no concitirá el consenso social sólo a través de advertencias, denuncias y llamados de atención. Su desafío es lograr que el problema ambiental sea precodificado, es decir, seleccionado culturalmente. El riesgo ambiental debe ser etiquetado y clasificado en categorías existentes de responsabilidad, ser incorporado por las estructuras institucionales, ya que los debates sobre riesgos físicos son determinados por cuestiones morales y políticas (Vessuri, 1994: 206 a 208).

Para K. Milton (1997) la antropología puede ayudar a buscar modos de vida sostenibles a un nivel general:

Mientras los estudios ecológicos pueden determinar qué prácticas humanas son ambientalmente benignas y cuáles perjudiciales, los análisis antropológicos pueden revelar qué formas de ver el mundo fomentan prácticas benignas o perjudiciales a la vez que son fomentadas por ellas. La antropología puede por lo tanto ayudar a desarrollar una comprensión de lo que podría implicar un modo de vida sostenible no sólo desde el punto de vista del trato físico que recibe el ambiente sino desde el punto de vista de qué tipos de valores, creencias, estructuras de parentesco, ideologías políticas y tradiciones rituales podrían contribuir a estas prácticas sostenibles.

Intentado tender un puente teórico entre la antropología y el discurso ambiental contemporáneo señala que hay una amplia gama de necesidades y de valores, además de los meramente prácticos, que deben tenerse en cuenta para garantizar el éxito de los programas que pretenden cambiar el comportamiento público: "Es nuestra cultura en su globalidad, y no sólo parte de ella, lo que nos sitúa dentro del mundo, lo que le da sentido para nosotros y orienta nuestras acciones; acciones que, cualesquiera que sean, se realicen o no con propósitos materiales, suelen acarrear consecuencias medioambientales".

Considera que la diversidad cultural no ha de consistir necesariamente en la preservación de lo que ya existe

puesto que la creación de nuevos modos de comprender el mundo, proceso que según se dice tiene lugar dentro del contexto más amplio de 'globalización', podría también generar modos de vida sostenibles. Pero la conservación de la diversidad cultural como tal podría llegar a ser tan importante para el futuro de nuestra especie como la conservación de la biodiversidad lo es para el futuro de la vida misma.

Dentro de la antropología del desarrollo, la metodología y reflexión antropológica ha sido utilizada para cuestionar y descalificar el proyecto desarrollista concentrándose en 1) evidenciar los problemas generados a partir de la aplicación de sus programas, 2) la desconstrucción de los discursos que lo sustentan y promueven, y 3) analizar sus instituciones. Desde esta postura se rescatan formas sociales y económicas guiadas por racionalidades diferentes a la hegemónica 
surgidas como reacción al desarrollo o que han resistido su influencia y se denuncian relaciones de dominación y poder. Los problemas de pobreza, género, salud, vida rural y ecología (destrucción/protección del medio ambiente) son abordados desde una perspectiva progresista y culturalista.

Arturo Escobar busca situar el debate sobre la sostenibilidad ecológica y cultural en un marco de trabajo más amplio. Sus análisis intentan dar forma "a la imaginación de alternativas al orden actual de cosas" (globalización, capitalismo, mercantilización, masificación cultural). Apunta que se requiere de una antropología de la globalización formulada sobre la necesidad de identificar socialmente los discursos significativos de la diferencia -cultural, ecológica, económica, política- y los modos como dichos discursos pueden operar en la articulación de alternativas al orden hegemónico:

Esa antropología de la globalización examinaría las múltiples maneras de construir hoy en día la cultura, la naturaleza o la identidad, así como la producción de diferencias a través de procesos históricos-espaciales que no son únicamente el producto de fuerzas globales -ya sean éstas el capitalismo, las nuevas tecnologías, la integración de mercados o cualquier otra-, sino que también están ligadas a los lugares y a su defensa. Es importante hacer visibles las múltiples lógicas locales de producción de culturas, identidades o prácticas económicas y ecológicas, que están brotando incesantemente desde comunidades de todo el globo (Escobar, 2000: 205).

Sugiere que la base de las propuestas de desarrollo sostenible deberían ser los distintos sistemas de significados y usos de la naturaleza presentes en modelos culturales y prácticas no-capitalistas (Escobar, 2000: 203), ya que en ellos se pueden contemplar los conjuntos indisociables de significados y usos de lo natural como dotados, al menos potencialmente, de un significado económico alternativo:

En muchos lugares del mundo, los campesinos han mostrado que mantenían un modelo de actividad económica que es al menos parcialmente diferente de las construcciones económicas modernistas, en términos de propiedad, racionalidad, mercado y eficiencia. Las economías comunales se asientan sobre lugares -por mucho que no se limiten a ellos, al participar en mercados translocales- y, a menudo, reposan sobre la explotación del 'común', que consiste en tierra, recursos materiales, conocimiento, ancestros, espíritus, etc. (Escobar, 2000: 202 y 203).

Por su parte María Eugenia Bozzoli señala que la pauta de desarrollo adoptada por un país es acompañada de modalidades específicas de uso de los recursos naturales así como de formas asociadas de desperdicio y contaminación del medio ambiente. Si se quiere desarrollar una estrategia cultural a ávor de la conservación del medio es indispensable reconocer todas las necesidades económicas y ambientales de la población:

- $\quad$ las expectativas acerca del futuro que la gente tiene

- la cooperación asociada a una distribución equitativa de los recursos

- estimular un sentido de identidad ligada al orgullo y conocimiento de los elementos culturales nacionales, regionales y locales

- $\quad$ ser cautelosos hacia las influencias externas que agravan los problemas de contaminación, delincuencia, adicción, etc.

- $\quad$ preservar la diversidad cultural

- tener en cuanta la ética

- involucrar a todas las instituciones en esta estrategia.

Bozzoli subraya la pertinencia de atender a los grupos sociales cuyas orientaciones culturales y sus actividades económicas pueden tener un fuerte impacto en la conservación del medio 
ambiente, entre los que menciona: comunidades indígenas, leñadores, campesinos que utilizan el sistema de tumba y roza, criadores de ganado, y la población urbana asociada al desarrollo industrial. El seguimiento de estos grupos puede rendir frutos a la hora de elaborar leyes, diseñar campañas publicitarias y programas educativos (Bozzoli, 2000: 275 a 279).

Eduardo Bedoya y Soledad Martínez exploran la dimensión antropológica del problema ambiental retomando conceptos de la economía política (procesos de mercantilización; las clases sociales; reproducción simple y reproducción ampliada; rol del Estado; el problema del poder; la sobredeterminación social de la población en su relación con los ecosistemas).

Señalan que la expansión de la economía de mercado en las sociedades no capitalistas provoca, entre otros efectos, la mercantilización de la mano de obra y de la tierra, ambos procesos generan consecuencias irreversibles sobre la cultura local y los correspondientes ecosistemas. La mercantilización de la mano de obra se expresa en migraciones, en este proceso se pierde el vínculo con la tierra y los conocimientos más adecuados sobre la naturaleza; también se afecta, por otra parte, el mantenimiento y la construcción de infraestructura, lo que favorecería el proceso productivo. La difusión del mercado de tierras causa un resquebrajamiento de la solidaridad intergeneracional de un grupo étnico determinado (Bedoya y Martínez, 2000: 144).

Las racionalidades económicas implican una relación específica con la naturaleza. Indican que la producción de valores de uso para el consumo familiar en la regiones rurales de los países menos industrializados, a pesar de la expansión de la racionalidad mercantilista, no ha desaparecido, ya sea por una reproducción voluntaria de formas no capitalistas o como estrategia de supervivencia ante la marginación.

Sea cual fuere la razón de la reproducción de dicha racionalidad, lo importante es remarcar que, en numerosas ocasiones, y sobre todo cuando se trata de sociedades indígenas que reproducen ciertos espacios de reproducción simple, la relación con la naturaleza suele ser sumamente compleja (Bedoya y Martínez, 2000: 147 y 148).

Observan una interacción entre el Estado, la estructura de clases y la forma de extracción del excedente. Ante el surgimiento de un conflicto territorial, el Estado se inclina por uno u otro grupo social involucrado a través de una política explícita o de una conducta aparentemente negligente que favorece a los intereses de una de las partes, siendo, generalmente, los grupos con mayor poder económico y político los beneficiados. El mayor deterioro de las condiciones de vida de la población rural y la degradación ambiental consecuencia del inadecuado manejo de recursos es el resultado (Bedoya y Martínez, 2000: 150 a 152).

Señalan, en una crítica a las posturas neomalthusianas, que la causa de que la población pueda constituir un auténtico problema ecológico no radica en el mayor o menor número de personas, sino en la racionalidad económica de las diferentes formas de producción y sistemas sociales. La presión poblacional sobre los recursos es consecuencia de una sobredeterminación social (Bedoya y Martínez, 2000: 155).

Subrayan la necesidad de analizar los proyectos de desarrollo sostenible, ya que estos pueden conducir al fortalecimiento de los sectores más ricos, a la diferenciación socioeconómica y a la marginación de la mujer si no se pone especial atención a los elementos utilizados en su metodología, ya que pueden ignorar la lógica y dinámica de las comunidades intervenidas (Bedoya y Martínez, 2000: 157-162).

A partir de la segunda mitad del siglo XX la reflexión e investigación antropológica puso mayor atención en la vida en las ciudades y el proceso de urbanización. El estudio de minorías étnicas, migrantes rurales, asentamientos pobres, expresiones subculturales ${ }^{9}$ y contraculturales $^{10}$ y

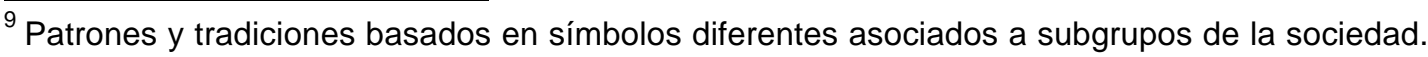


recientemente los efectos culturales de la globalización son algunos de los temas que aborda la antropología urbana.

Mario Rabey y Omar Jerez (2000) abordan el problema de la sostenibilidad en los asentamientos urbanos. Indican que la construcción de conocimientos en cada sector social y barrio es diferente, lo que produce una gran heterogeneidad cognoscitiva. Esta diversidad produce conflictos. Sin embargo, señalan, este no es el problema, ya que se trata de conocimientos

que en sí mismos son producto de interacciones; no solamente son dinámicos sino que se producen por las confrontaciones, los conflictos, las articulaciones, las interacciones entre distintas líneas cognoscitivas que aparecen y desaparecen, se desarrollan, nacen, decaen y se vuelven a retomar después. No son conocimientos producidos dentro de los límites de los sistemas socioculturales, sino en las interfaces donde se entrecruzan.

El problema es que la gran cantidad de conocimiento existente en los ámbitos locales, tanto de estratos sociales altos como bajos, es ignorado.

Empezamos a percibir una situación en que, a diferencia de lo que decía Lyotard de que vale tanto el conocimiento de los más débiles como el de los más poderosos, en realidad lo que está sucediendo es que se ha desvalorizado completamente los conocimientos construidos por cada uno de los actores sociales por su cuenta, al establecerlos como conocimientos fragmentarios. Así, se los ha desvalorizado y no hay ningún conocimiento que los reemplace, al haberse declarado la pérdida de legitimidad de los grandes discursos hegemónicos. En realidad, en la postmodernidad se ha estado dejando vacío el espacio del conocimiento. Atrás de la metáfora de Feyerabend que dice que se ha llenado el espacio de conocimiento con la diversidad y la multiplicidad de conocimiento y el todo vale, hay otra metáfora más profunda: nada vale. No es que todo puede suceder, sino ¿qué importancia tiene cómo suceden las cosas o cómo se dice que son las cosas? Entonces lo que sucede es la insustentabilidad cultural.

Pero esos conocimientos ignorados generan el crecimiento de las zonas urbanas:

Hay tanto conocimiento disponible y, como mencionamos antes, parece que ninguno sirve. Sin embargo, las cosas siguen pasando, la gente sigue viviendo, las ciudades se siguen construyendo. Lo que necesitamos ahora es descubrir cuál es la lógica en la cual todas estas cosas están pasando.

El desafío, consideran, es generar espacios de consenso, es decir, la interacción, articulación y conexión entre los actores para posibilitar el surgimiento de propuestas reconocidas como válidas por el conjunto de culturas -agentes sociales-. En otras palabras: rescatar los conocimientos.

Cuando el investigador desarrolla una respuesta para un ámbito local, que es una encrucijada de fuerzas, de acciones, de perspectivas culturales muy distintas, se está generando un posible modelo para aplicar a escalas mucho mayores. Estas reflexiones permiten configurar una idea general de sustentabilidad, en relación con el rol del antropólogo. La antropología de la sustentabilidad no se constituye como una antropología teórica acerca de los sistemas mundiales o las regiones sustentables. Es un conjunto de prácticas, en ámbitos locales donde se manifiestan fuertes y densos entrecruzamientos de culturas, donde la actuación del antropólogo, actuando conjuntamente con otros profesionales y con los

\footnotetext{
${ }^{10}$ Conjunto de manifestaciones que exteriorizan una rebelión contra las actividades ideológicas o artísticas dominantes.
} 
diversos agentes sociales, puede generar modelos, que sí son aplicables a escalas mucho mayores.

La insostenibilidad, concluyen, reside en la falta de incorporación de los conocimientos de los diversos actores y sectores sociales en la planificación urbana.

Como hemos podido apreciar, la antropología comienza no sólo a estudiar casos concretos relacionados con la sostenibilidad, sino que ha aportado elementos para su teorización y gestión, esto es relevante en vista de la tendencia prevaleciente en los equipos planificadores que ha descuidado el factor humano en la promoción del desarrollo sostenible. Cabe destacar que en los trabajos citados se subraya la importancia de conservar la diversidad cultural; se analiza el problema de la sostenibilidad concentrándose: 1) en el papel de los grupos que tienen relación directa con los recursos naturales (productores rurales); y 2) en la necesidad de rescatar/difundir conocimientos y valores ambientalmente adecuados. No se discute el impacto ecológico causado por la gran mayoría de la población (consumidores urbanos), la cual tiene una relación indirecta con los recursos y genera más contaminación. Tampoco se menciona a los medios de comunicación. Como veremos en el capítulo siguiente, éstos no sólo influyen en los hábitos de consumo de los residentes de las crecientes zonas urbanas, sino en la producción y reproducción tanto de valores y conocimientos como de representaciones, significaciones, modos de pensamiento y estilos de vida.

Ciertamente la relación que los sujetos tienen con los medios no es homogénea y acrítica (Dickey, 1997; Villasante, 1998; Nitz, 2000), pero éstos son un elemento central en la conformación de la personalidad contemporánea. Lo que está cambiando, indica José Manuel Pérez, es la mentalidad: "la percepción, la atención, la memoria, el discernimiento, la conceptualización y otras facultades que forman la inteligencia humana se encuentran en territorios nuevos e inexplorados". Añade:

Las imágenes visuales, las cinéticas, las táctiles y, probablemente, hasta las olfativas se van a convertir, de hecho lo están siendo ya, en lenguajes tan articulados y tan racionalizados que servirán -siempre han servido- de soporte del pensamiento. Pero, en la medida en que introducen una nueva facticidad y en que son operativos físicos concretos, son también fuentes de nuevas sensibilidades. Por otra parte, y como se está comprobando en el comportamiento de muchos niños y adolescentes, esto está dando lugar a la aparición de una nueva sentimentalidad, porque el sentimiento es la expresión y el resultado de una sensibilidad (Pérez, 2000: 102).

Pérez es más positivo que Giovanni Sartori (1998) quien ve en el 'nuevo sujeto histórico' (homo videns) a un ser con menor capacidad de abstracción, es decir, menos inteligente. Este nuevo sujeto histórico (el individuo de la era de la información), poseedor de otra sensibilidad e inteligencia, es y será la 'población objetivo' de la gestión del desarrollo sostenible de los asentamientos humanos. Entender el impacto antropológico (en el sujeto) de la mediatización es fundamental si se pretende transitar a una sociedad ecológica. 


\section{Marco de referencia}

\section{Medios y reproducción ideológica}

La noción de 'ideología' suele identificarse con creencias falsas, manipulaciones y mentiras. En un intento por elaborar una nueva concepción, partiendo de nociones más inclusivas y menos peyorativas, Teun A. van Dijk define este concepto

como la base de las representaciones sociales compartidas por los miembros de un grupo. Esto significa que las ideologías les permiten a las personas, como miembros de un grupo, organizar la multitud de creencias sociales acerca de lo que sucede, bueno o malo, correcto o incorrecto, según ellos, y actuar en consecuencia (Van Dijk, 1999: 21).

Del trabajo de Van Dijk -que él mismo define como una 'aproximación multidisciplinaria'-, además de su concepto de ideología, se tomarán sus reflexiones sobre la relación entre ideologías y valores, el origen de las ideologías y la forma como éstas se comunican (reproducen).

Indica Van Dijk que las ideologías pueden influir en lo que se acepta como verdadero o falso, especialmente cuando dichas creencias son consideradas importantes para el grupo. En este sentido, un sentido epistemológico,

las ideologías también pueden formar la base de argumentos específicos a favor de, y explicaciones sobre, un orden social particular, o efectivamente influir en una comprensión particular del mundo en general. Nótese, sin embargo, que las ideologías dentro de este marco no son simplemente una 'visión del mundo' de un grupo, sino más bien los principios que forman la base de tales creencias (Van Dijk, 1999: 21)

Las ideologías sirven a sus propios fines y son una función de los intereses materiales y simbólicos del grupo; operan tanto en el nivel global de la estructura social, es decir, como 'monitor' mental compartido socialmente que guía la competencia, el conflicto, la lucha y la desigualdad sociales, como en el nivel de las prácticas sociales situadas en la vida cotidiana (Van Dijk, 1999: 22).

Las ideologías no son definidas solamente en términos cognitivos sino también en términos de grupos sociales, relaciones de grupo e instituciones, a un micronivel, y en términos de prácticas sociales, a un macronivel. No están 'por encima de' o 'entre' las personas, los grupos o la sociedad, sino que son parte de la mente de sus miembros: "Esto no significa que sean, en consecuencia, individuales o solamente mentales. Por el contrario, como las lenguas, las ideologías son tanto sociales como mentales" (Van Dijk, 1999: 23 y 71).

Las ideologías consisten en aquellas creencias sociales generales y abstractas, compartidas por un grupo, que controlan u organizan su conocimiento, opiniones y actitudes más específicas (Van Dijk, 1999: 72).

Sólo podemos comprender y analizar la base cultural común como ideológica si tenemos posibles alternativas, otros ejemplos, otras culturas, conflictos entre culturas, o cuando un grupo específico dentro de una sociedad o cultura desafía las creencias sociales de la base común. En otras palabras, una vez más se aplica el principio de la relatividad: la base cultural común sólo puede ser llamada ideológica en un nivel de análisis más elevado, comparativo, universal o histórico. Si todos los miembros de una cultura creen, por ejemplo, en la existencia de Dios, entonces esa creencia religiosa ya no es ideológica sino simplemente conocimiento compartido dentro de esa cultura. Es decir, no hay ningún grupo dentro de esa cultura que esté en desacuerdo, cuestione o de alguna manera ofrezca una visión alternativa de la sociedad en ese respecto (Van Dijk, 1999: 74). 
Si las creencias específicas del terreno común realmente son del interés de un grupo dominante particular "y aún así se dan por sentadas, son tácitamente aceptadas e incuestionadas por otros grupos, entonces ya distinguimos entre diferentes grupos y sus diferentes intereses, de modo que en ese caso las creencias de base común serían realmente creencias de un grupo impuestas en la sociedad o cultura como un todo" (Van Dijk, 1999: 74).

Sobre la relación ideologías-valores, apunta que éstos desempeñan un papel central en la construcción de las ideologías, ya que son los puntos de referencia de la evaluación social y cultural: "Tal como el conocimiento y las actitudes, están ubicados en el dominio de la memoria de las creencias sociales. Esto es, no tomamos a los valores como abstracciones sociales o sociológicas, sino como objetos mentales compartidos de cognición social". Los valores forman la base de todos los procesos de evaluación y, en consecuencia, de opiniones, actitudes e ideologías: "Así, si las ideologías son la base de las creencias de un grupo, y si los valores son a su vez más amplios y fundamentales, éstos deben ser la base de los sistemas evaluativos de una cultura como un todo. En efecto, los valores son los pilares del orden moral de las sociedades". Indica que los valores "parecen estar organizados por las dimensiones fundamentales de las experiencias cotidianas y la observación, al igual que la acción y las organización sociales". El proceso de selección y construcción por medio del cual los valores se incorporan a las ideologías sirve a los propios intereses de éstas (Van Dijk, 1999: 101 a 103).

Al profundizar sobre el origen de las ideologías (quién las 'inventa'), apunta:

Una cuestión, formulada a menudo en psicología política, es que aún no se sabe si, en verdad, grandes grupos de personas tienen efectivamente una ideología más o menos explícita o articulada. Ellos pueden compartir unos pocos principios y objetivos, pero no una ideología 'completa'. Esas ideologías más detalladas y explícitas están, entonces, atribuidas específicamente a los líderes, los intelectuales, las elites o, ciertamente, los 'ideólogos' de tales grupos (Van Dijk, 1999: 218).

Los expertos tienen acceso a un número creciente de formas variadas del discurso, pueden comunicar más a menudo y más explícitamente las ideologías de su grupo y pueden, en consecuencia, desarrollar sistemas ideológicos más minuciosos y más 'articulados' (Van Dijk, 1999: 219).

Precisa Van Dijk que es importante investigar no sólo de dónde vienen las creencias ideológicas, sino también cómo se comparten y comunican:

La evidencia histórica sugiere que al menos varias ideologías parecen ser, primero, inventadas y propagadas de arriba hacia abajo: un pequeño número de líderes, intelectuales o 'ideólogos' más o menos conscientes y articulados, tienden a formular los principios ideológicos de un grupo. Entonces, a través de formas diversas de discurso intragrupal (debate, mítines, propaganda, publicaciones) y otras prácticas institucionales, esas ideologías se propagan lentamente entre los miembros del grupo y la sociedad en general [...] Sólo los líderes u otras elites pueden tener el acceso a los medios de comunicación y al discurso público que permiten la propagación y la reproducción de las ideologías (Van Dijk, 1999: 221).

Una condición importante para este proceso de participación y reproducción social es que los miembros del grupo puedan identificarse con el grupo y su ideología:

Aun cuando las 'ideas', o los argumentos de esas ideas, puedan ser inicialmente 'inventados' o al menos expresados públicamente por individuos específicos, pueden constituir una ideología solamente cuando son compartidos y 'sostenidos' por un grupo de personas cuyos intereses estén relacionados con esas ideas en primer lugar [...] Es en este sentido que las ideas de elite y la invención de las 
ideologías no están únicamente condicionadas por la aceptación de esas ideas por los grupos sociales, sino al mismo tiempo por las mismas experiencias y los discursos (posiblemente informales) de los miembros del grupo ${ }^{11}$ (Van Dijk, 1999: 221 y 222).

Además de reproducirse mediante el discurso, las ideologías lo hacen en y por el texto y la conversación de familias, grupos de pares, escuelas, medios de comunicación, iglesias, sindicatos, clubes, movimientos sociales, agencias, negocios corporativos, etc. Las instituciones y organizaciones son la contrapartida 'práctica' de las ideologías: "Del mismo modo en que las ideologías organizan la cognición de grupo, las instituciones y las organizaciones organizan las prácticas y a los actores sociales" (Van Dijk, 1999: 235). Identifica a la familia, las iglesias, las escuelas, las universidades y los medios masivos de comunicación como las instituciones encargadas de la reproducción ideológica, señalando a las escuelas y universidades como el medio más importante para la reproducción de las ideologías dominantes en la sociedad. Las estructuras, estrategias y prácticas de las instituciones sociales

no sólo necesitan ser orientadas por razones prácticas de organización, eficiencia, distribución de roles o recursos, o por el logro de objetivos; también pueden reflejar y faciliar los intereses ideológicos. Las lecciones, los libros de texto, los exámenes, las tareas, las correcciones y las sanciones en las instituciones educacionales, de tal modo, pueden estar organizadas en parte por objetivos basados en una ideología para enseñar e inculcar 'las cosas correctas', incluy endo las ideologías 'correctas'. De un modo menos organizado, lo mismo ocurre con los diversos discursos de socialización en la familia (Van Dijk, 1999: 237).

Sin embargo, agrega:

A pesar del papel omnipresente de la educación, en las sociedades mediatizadas contemporáneas gran parte de la tarea de la familia, de la Iglesia y de la escuela ha sido asumida por los medios masivos de comunicación como institución. Mientras que éstos están principalmente orientados hacia la producción de información y entretenimiento, son al mismo tiempo las instituciones más complejas para la expresión y el cuestionamiento públicos de las ideologías. Sin los medios de comunicación, y dado el papel reducido de la iglesia y la limitación de la escolaridad a niños y adolescentes, el debate público sobre asuntos corrientes y el conocimiento compartido sobre lo que sucede en la sociedad y el mundo sería impensable en el presente. Puede conjeturarse, por lo tanto, que en la reproducción de las ideologías los medios desempeñan un papel central. Las representaciones sociales son fácil y ampliamente compartidas debido a estas formas de discurso público accesible, y lo mismo es cierto para las ideologías que subyacen bajo estas representaciones (Van Dijk, 1999: 236).

De una manera menos explícita, pero por eso tal vez más penetrante e influyente, son reproducidas las ideologías de las elites dominantes (Van Dijk, 1999: 235).

La producción de noticias, publicidad, documentales, películas, juegos, 'talk shows' y otros espectáculos, entre muchos otros géneros mediáticos, pueden por lo tanto,

\footnotetext{
11 La influencia de la elite de arriba hacia abajo, destaca Van Dijk, es el caso del origen del movimiento ecologista: "Inicialmente el público en general estaba escasamente consciente de las condiciones y las consecuencias de la contaminación. Sólo cuando la amenaza para la salud y la supervivencia, tanto de la humanidad como de la naturaleza, fue claramente demostrada por la investigación (Club de Roma) y por ejemplos concretos (como Chernobyl), los ecologistas pudieron ser un movimiento popular. La percepción y la forma de conciencia, de este modo, a menudo es un constructo social, y las elites pueden desempeñar un papel en la invención de tal constructo" (Van Dijk, 1999: 222).
} 
examinarse en detalle para ver cómo organizan las acciones, los discursos, los sonidos y las imágenes de modo tal que la producción y reproducción ideológicas, también entre la audiencia, sean más efectivas (Van Dijk, 1999: 237).

Las rutinas, los actores, los eventos y los acuerdos institucionales en la confección de noticias, programas de actualidad, documentales, espectáculos y otras categorías de discurso de los medios están sesgados hacia la reproducción de un conjunto de ideologías dominantes (Van Dijk, 1999: 237).

A pesar de las diferencias personales y de la libertad de los usuarios de los medios en su procesamiento y utilización del discurso mediático, los efectos ideológicos generales de los medios son innegables: la gama de ideologías sociales aceptables es casi idéntica a la de aquellas que tienen acceso preferencias a los medios masivos de comunicación. Las normas y los valores fundamentales, la selección de asuntos y tópicos de interés y atención (determinación de la agenda), el conocimiento selectivo, si no parcializado, sobre el mundo, y muchos otros elementos o condiciones de control ideológico, actualmente se deben, en gran medida, a los medios masivos, o, indirectamente, a los grupos e instituciones, como los de la política, que tienen acceso preferencial a los medios. Por supuesto, habrá debate, oposición, diferencias de opinión, al igual que diferencias entre los periódicos. Sin embargo, todo esto se da dentro de los límites de una variación ideológica tolerable [...] El papel omnipresente de instituciones ideológicas (los medios masivos especialmente) explica las propias condiciones sociales de las ideologías, es decir, las formas en que son compartidas por grandes cantidades de personas y grupos (Van Dijk, 1999: 238).

Profundizando sobre las estrategias de control ideológico indica que las ideologías de elite pueden ser adoptadas más ampliamente entre la población en general o entre grupos dominados específicos bajo las siguientes condiciones:

1) Las ideologías dividen a los grupos no dominantes por ser al menos atractivas para, o en beneficio de, algunos grupos no dominantes y evitar, de esta forma, la solidaridad dentro del grupo y la organización del contrapoder (ejemplo: el sexismo y el racismo).

2) Se evita la solidaridad interna en los (importantes) grupos no dominan-tes creando divisiones dentro del grupo y dirigiéndose a los miembros como individuos (ejemplo: dividiendo a las mujeres entre las 'feministas' y las 'otras').

3) No hay alternativas populares (fuertes) a las ideologías de elite, o estas alternativas son desconocidas o marginadas (ejemplo: el antineo-liberalismo está excluido de los medios).

4) Las elites (y especialmente los editores de los medios de comuni-cación) evitan o limitan el acceso al discurso público de los líderes de grupos no dominantes, o los marginan o desacreditan entre la pobla-ción en general o, incluso, entre sus propios grupos (en los medios masivos más importantes no están los grupos 'radicales' -feministas, políticos, antirracistas, etc.).

5) Las elites adoptan, aparentemente, las ideologías populares, pero de un modo muy moderado, con lo cual se evitan conflictos importantes con sus intereses (ejemplo: el ecologismo).

6) Si las ideologías de elite son ampliamente nconsistentes con las ideologías relativamente fuertes y conocidas de los grupos dominados, las elites tienen el instrumento especial de acceso y control de los medios de comunicación y estrategias discursivas de manipulación del conocimiento y las opiniones (ejemplo: enfatizando las consecuencias ideológicas que son menos inconsistentes con los intereses de los grupos dominados, o restando énfasis a aquellas que son inconsis-tentes con esos intereses -el neoliberalismo, el nacionalismo) (Van Dijk, 1999: 233 y 234). 
Apunta que a pesar de la gran variedad y confusión ideológica de la sociedad contemporánea, la evidencia sugiere con fuerza que, dado el creciente control de los medios por las elites, y el creciente papel de los medios de comunicación como el mayor instrumento de control ideológico de la sociedad, las ideologías de elite generalmente tendrán a ser dominantes. Sin embargo, las ideologías populares pueden convertirse en dominantes solamente: a) si tienen un amplio sustento dentro de uno o varios grupos dominados; b) si los líderes de tales grupos tienen acceso al discurso público y, sobre todo, a los medios masivos (lo que implica que al menos algunos medios masivos necesitan estar en connivencia con ellos); c) si estas ideologías son fundamentalmente inconsistentes con los intereses de la mayoría de las elites (Van Dijk, 1999: 234).

\section{Medios y construcción de sentido}

Fernando García indica que la configuración individual del sentido (o intencionalidad) y la configuración pública del sentido se asientan en un trasfondo producido y reproducido en la práctica social (García, 1995: 497). El trasfondo (marco de sentido) es un conjunto de conocimientos prácticos (know-how), habilidades, capacidades y disposiciones (García, 1995: 502).

Para comprender el sentido de unas acciones no debemos verlo como producido por el contexto o por el genio del autor, sino localizarlo en un campo específico de comunicación, conocimiento y poder, cuya lógica interna está construida histórica y políticamente y se manifiesta tanto en la encarnación del autor (o corporeidad como base de símbolos y significados) y en la configuración del contexto como en su interacción (García, 1995: 525).

El sentido o significado de una acción

es su carga simbólico-representativa que rebasa la materialidad conductual, está ligada a la narratividad discursiva y, una vez captada, permite la comprensión de la acción y eventualmente su explicación. La producción y reproducción de sentido, signos y significados, y más concretamente la producción y reproducción de contenidos intencionales, aparece así como un proceso práctico, interactivo e impreso en la experiencia de los agentes (individuales y colectivos) (García, 1995: 495).

La intencionalidad sería resultado del compromiso personal del sujeto con algunas de las prácticas, discursos e instituciones que dan significado (valor, sentido y efecto) a los acontecimientos del mundo (García, 1995: 516).

Muniz Sodré indica que con la mediatización los significados compartidos por la sociedad son creados y transmitidos por los medios de comunicación, que a su vez están en función de los intereses del mercado, dependiente de la innovación tecnológica. A este trabajo cultural realizado por las prácticas comunicativas denomina 'tecnocultura', 'cultura de la comunicación', 'cultura mediatizada' o 'reinvención cultural'. Esta nueva cultura abarca los medios de comunicación de masas 'tradicionales' (televisión, radio, periódicos, revistas, discos, publicidad, cine) y las formas comunicacionales del presente tecnológico, "los 'rizomas', característicos del espacio que han ido creando en forma progresiva las redes telemáticas" (Sodré, 1998: 10 y 11).

En la sociedad mediatizada, tecnocultura es una designación, entre otras posibles, para el campo comunicacional como instancia de producción de bienes simbólicos o culturales, pero también para la impregnación del orden social por los dispositivos maquínicos de estetización o culturalización de la realidad. Todo esto sugiere una especie de 'reinvención' de la cultura (Sodré, 1998: 9).

La 'tecnocultura' es la universalización sígnica de la alianza entre la comunicación, la tecnología y la economía de mercado: "En el proceso de globalización de las culturas del mundo, el consumo, como imperativo del mercado, aparece como una doctrina sin nombre preciso (neoliberalismo, tal 
vez), con pretensiones de sustitución de las formas representativas tradicionales" (Sodré, 1998: 10).

Renato Ortiz señala que el mercado en el contexto de la modernidad-mundo adquiere un peso desprop orcionado:

Se trata de una instancia no sólo económica, como suelen imaginar los economistas, sino también productora de sentido. Lejos de ser homogéneo, según pensaban los teóricos de la comunicación masiva, el mercado crea diferencias y desigualdades. Baste ver el universo del consumo y de los estilos de vida. A través de los objetos consumidos, los individuos expresan y reafirman sus posiciones de prestigio o de subordinación. El consumo requiere disponibilidad financiera y capacidad de discernir (hay una educación para el consumo). Las marcas de los productos no son meras etiquetas, agregan a los bienes culturales un subvalor simbólico consustanciado en la griffe que lo singulariza en relación a otras mercancías (Ortiz, 2000: 52).

Lo que socialmente está planteado para ser debatido por las teorías de la comunicación, indica Sodré,

es la transformación acelerada de las sociedades industriales y el papel en ellas desempeñado por los medios de comunicación llamados 'de masas' o simplemente 'media'. Dicho de otra manera, se trata de problematizar las nuevas formas de discursividad engendradas por las tecnologías avanzadas de la información.

Esto ocurre en el momento en el que el nuevo modo de organización de las sociedades plenamente industrializadas busca integrar la producción y el consumo de bienes culturales al movimiento de acumulación del capital en escala monopolista y transaccional. La cultura sirve de manera cada vez más directa a la reproducción ampliada de las relaciones capitalistas (Sodré, 1998: 24).

Lo que ocurre actualmente es la operacionalización de los intercambios sociales bajo la égida del signo, "lo que equivale a una transformación en espectáculo de la vida social. En la sociedad del espectáculo, el poder o el control son discursivamente sutiles" (Sodré, 1998: 25).

Las instituciones, las prácticas sociales y culturales se articulan en la sociedad mediatizada directamente con los medios de comunicación de tal manera que éstos se convierten progresivamente "en el lugar por excelencia de la producción social del sentido, modificando la ontología tradicional de los hechos sociales" (Sodré, 1998: 30).

La realidad virtual, comprendida como un 'real' anclado en el plano de la representación pura, altera radicalmente nuestra percepción y hace que se difumine la realidad tradicional. Las pantallas, en todas sus formas, constituyen el espacio en el que las imágenes y los dígitos crean una nueva sintaxis del mundo (Sodré, 1998: 34).

Es bastante viable, añade, que la hipótesis de que, junto con bs sectores mensurables del funcionamiento social contemporáneo, opere una lógica de la cultura que asume abiertamente la ilusión como vía para la experiencia de lo real, en oposición a la seriedad de la razón institucionalizada. Las expresiones vitalistas que colocan en primer plano el ocio, la diversión, el goce del ahora, siempre fueron, y continúan siendo, práctica corriente en amplios sectores (las clases populares) de la vida social (Sodré, 1998: 38).

Para tales sectores, la comunicación no se restringe a lo que han querido hacer de ella los mass-media con sus proyectos mercantilistas o de divulgación. El lenguaje, una vez puesto en movimiento, ya no pertenece a su productor. De igual 
manera, la comunicación desencadenada por el campo tecnocultural en la contemporaneidad puede convertirse en espacio de apropiación de mecanismos semióticos y de redefinición de identidades sociales (Sodré, 1998: 38 y 39).

Es comprensible que la comunicación, como la forma de la reinvención de la cultura, desempeñe un papel fundamental en toda esta nueva constelación histórica, "donde el avance tecnocientífico aparece como la última de las utopías del capital, y los mercados financieros elaboran las principales normas de funcionamiento de la vida social" (Sodré, 1998: 39).

Subraya que el nuevo orden suscitado por la información, al mismo tiempo en que se instituye, produce una desorganización de ordenamientos tradicionales:

Las estrategias de universalización operadas por las teletecnologías y por los códigos culturales del mercado contribuyen a la disolución del sentido de agencias socializantes que no están en consonancia con el mercado o con la tecnología de punta, acelerando la crisis histórica de la representación (Sodré, 1998: 53).

En ese sentido se orientan las hipótesis de que la información 'devora la comunicación y lo social' sin producir sentido verdaderamente.

Estamos lejos del discurso humanista de los siglos XVIII y XIX, que justificaba por la 'libertad' el esfuerzo de desarrollo racionalista del principio de la subjetividad. Las prácticas clásicas del sujeto (expresión, emancipación, ciudadanía) se contradicen con las 'prácticas del objeto' o de la 'masa', las que, siendo reguladas por el código de la sociedad neoliberal del mercado, dan su consentimiento a la cómoda resignación del consumo. La histórica realización social del hombre mediante la actividad política cambia por la liberación aduladora y autoerótica de los deseos.

[...] Así, contrariamente a la autodeterminación por el sólo 'dominio de la razón', se registran ilusiones (narcisistas) de autosuficiencia, que engendran formas regresivas de psiquismo (negación de las diferencias, de la muerte, así como la idealización excesiva) y encierro del individuo en relación al medio ambiente (Sodré, 1998: 55 y 56).

La cuestión de los medios de comunicación, como mecanismo de punta en el nuevo modelo de organización de la sociedad, es la de asegurar las lógicas contemporáneas de control social con la apariencia de reestructuración de los vínculos humanos que se pierden o se desvanecen. "Ya no se trata de luchas por la modernización o por los derechos civiles frente al Estado" (Sodré, 1998: 57).

\section{Medios y socialización}

Peter Berger y Thomas Luckmann definen la socialización como la inducción amplia y coherente de un individuo en el mundo objetivo de una sociedad o en un sector de él. La socialización primaria es aquella por la que el individuo atraviesa en la niñez, por medio de ella se convierte en miembro de la sociedad. La socialización secundaria es cualquier proceso posterior que induce al individuo ya socializado a nuevos sectores del mundo objetivo de su sociedad (Berger y Luckmann, 1999: 166). La re-socialización es un proceso semejante a la socialización primaria, ya que vuelven a atribuirse acentos de realidad; pero a diferencia de la socialización primaria ocurre un proceso de desmantelamiento de los anteriores elencos socializadores: es una transformación radical de la realidad subjetiva en donde ocurre una dependencia emocional a otros significantes (Berger y Luckmann, 1999: 197).

Melvin L. De Fleur y Sandra J. Ball-Rokeach aportan dos teorías para entender la forma como los medios de comunicación participan en el proceso de socialización: la teoría del modelaje y la teoría de las expectativas sociales. 
Señalan que la verdadera significación de las comunicaciones en la sociedad no descansa en sus efectos inmediatos sobre audiencias específicas sino en las influencias indirectas, sutiles y a largo plazo que ejercen en la cultura y en la organización de la vida social:

La sociedad y la cultura están en continuo proceso de cambio debido al despliegue constante de acontecimientos históricos, tales como guerras, depresiones o avances tecnológicos, y los cambios en las creencias y en el comportamiento de los individuos reflejan este proceso $\mathrm{y}$, en muchos casos, influyen en él. En los planos social y cultural, el establecimiento de nuevas reglas de interacción social, o la modificación de las viejas, proporciona nuevas pautas de conducta. (De Fleur y Ball-Rokeach, 1994: 263 y 264).

En las sociedades modernas los medios de comunicación se han convertido "en una fuente irresistible, ineludible y omnipresente de definiciones sobre cómo la gente debe comportarse. Por este motivo, es fundamental estudiar sus influencias a largo plazo en el proceso de socialización" (De Fleur y Ball-Rokeach, 1994: 270). La socialización, indican,

es la etiqueta de una serie compleja, multidimensional y a largo plazo, de intercambios comunicativos entre los individuos y distintos agentes sociales que dan como resultado la preparación del individuo para la vida en un entorno sociocultural. Desde una perspectiva individual, la socialización nos provee de lo necesario para comunicarnos, pensar, resolver problemas mediante el uso de técnicas aceptables por la sociedad y, en general, diseñar cuál va a ser nuestra específica forma de adaptación al entorno. Desde el punto de vista de la sociedad, la socialización lleva a sus miembros a una conformidad suficiente, de forma que se pueda mantener el orden social, la capacidad de previsión y continuidad (De Fleur y Ball-Rokeach, 1994: 271).

Una contribución importante para entender la forma en que las comunicaciones pueden desempeñar un papel en el proceso de socialización es la teoría del modelaje. Este término es útil para describir la aplicación de la teoría del aprendizaje social general a la adquisición de nuevos comportamientos a partir de las representaciones de los medios, los cuales son una fuente de modelos atractivos y fácilmente disponibles y proporcionan un modelaje simbólico a casi todas las formas concebibles de conducta (De Fleur y Ball-Rokeach, 1994: 281). El proceso del modelaje consiste en lo siguiente:

1. Un miembro individual del público observa o lee algo acerca de una persona (modelo) que está representado un modelo específico de acción en el contenido de los medios.

2. El observador se identifica con el modelo, es decir, cree que es como el modelo, quiere ser como el modelo, o ve al modelo como algo que vale la pena imitar.

3. El observador se da cuenta conscientemente -o inconscientemente llega a la conclusión- de que el comportamiento observado o descrito será funcional. Es decir, que la persona acaba creyendo que el comportamiento conllevará un resultado satisfactorio si se imita de una forma concreta.

4. El individuo recuerda las acciones del modelo cuando las confronta con las circunstancia pertinentes (la situación del estímulo) y reproduce el comportamiento como vía de respuesta a dicha situación.

5. La realización de la actividad reproducida en situaciones estimuladoras adecuadas reporta al individuo algún tipo de alivio, recompensa o satisfacción, lo que provoca la conexión entre los estímulos y las respuestas modeladas que han de ser reforzadas. 
6. El reforzamiento positivo increment a la probabilidad de que el individuo utilice la actividad reproducida como instrumento para responder a situaciones similares (De Fleur y Ball-Rokeach, 1994: 281 y 282).

Mencionan que los que diseñan, producen y distribuyen el contenido de los medios quizá no pretendan que sus representaciones del comportamiento humano sirvan como modelos para otros, y que los que adoptan formas de conducta que han aparecido o se han mostrado en los medios quizá no hayan buscado deliberadamente la exposición a pautas de comportamiento con el propósito de copiarlas de los modelos, "pero el caso es que lo hacen, sea consciente o inconscientemente" (De Fleur y Ball-Rokeach, 1994: 283).

Además de analizar a los medios como fuentes de modelos atractivos, De Fleur y Ball-Rokeach los estudian como fuentes de expectativas sociales:

Los medios de comunicación de masas son la fuente más importante de expectativas sociales modeladas en cuanto a la organización social de grupos específicos en la sociedad moderna. Es decir, en su contenido se describen o representan las normas, roles, categorías y sanciones de prácticamente todos los grupos conocidos en la vida social contempo-ránea (De Fleur y Ball-Rokeach, 1994: 290 y 291).

La teoría de las expectativas sociales está relacionada con las influencias de las comunicaciones de masas en la socialización, que provienen de sus representaciones de modelos estables de la vida grupal: "Estos modelos estables definen lo que se espera que hagan las personas cuando se relacionan con otros en la familia, interactúan con sus compañeros de trabajo, participan en cultos religiosos, estudian, adquieren hábitos de consumo, y toman parte en otras muchas formas de vida comunitaria" (De Fleur y Ball-Rokeach, 1994: 291). Resumen las ideas fundamentales de esta teoría:

1. Los modelos de organización social en forma de normas, roles, categorías y sanciones, correspondientes a tipos específicos de grupos, se representan con frecuencia en el contenido de los medios.

2. Estas representaciones de cualquier tipo de grupo en concreto pueden ser auténticas o no. Es decir, pueden ser fidedignas o engañosas, precisas 0 distorsionadas.

3. Los miembros del público, sea cual sea su relación con el mundo real, asimilan estas definiciones de forma que las mismas se convierten en sus series aprendidas de expectativas sociales acerca de cuál se espera que sea el comportamiento de los miembros de estos grupos.

4. Dichas expectativas serán una parte importante de los conocimientos preferentes de la gente sobre el comportamiento que, en los grupos, se requerirá a sus futuros miembros.

5. Las expectativas de la gente acerca del comportamiento de los miembros de muchos grupos que existen en su comunidad, o en la sociedad en general, son una parte importante de su conocimiento general sobre el orden social.

6. Las definiciones que deducimos de estas expectativas nos sirven como guías de acción, es decir que son definiciones sobre cuál ha de ser el comportamiento personal de los individuos hacia los demás, cuando éstos están desempeñando un rol específico, y cómo éstos actuarían con relación a los primeros en distintas circunstancias sociales (De Fleur y Ball-Rokeach, 1994: 292).

La teoría de las expectativas sociales es una explicación de las influencias indirectas y de largo alcance de los medios. Subrayan que las dos teorías expuestas pueden ayudar a explicar cómo ciertos contenidos y exposiciones de los medios juegan un papel en la socialización de la gente a largo plazo, en una sociedad en la que se puede acceder sin ningún tipo de problema a todo tipo 
de medios de comunicación. También intentan poner de manifiesto que las personas pueden utilizar los medios de comunicación como fuentes, sea de forma deliberada o inconsciente, para adquirir guías para un adecuado comportamiento que les suponga una ayuda en el proceso de adaptación al complejo mundo en el que viven (De Fleur y Ball-Rokeach, 1994: 293).

Indican que uno de los principales aspectos de nuestra actual transición hacia la era de las comunicaciones es que estamos en contacto, de forma creciente, con representaciones mediadas de un mundo social y físico complejo más que con los rasgos objetivos de nuestro restringido entorno personal (De Fleur y Ball-Rokeach, 1994: 334).

Por otra parte señalan que los símbolos y convenciones del lenguaje aceptados y utilizados por un grupo de gente específico modelan su percepción e interpretación del mundo físico y social, así como su actitud hacia el mismo (De Fleur y Ball-Rokeach, 1994: 335). Los símbolos y convenciones actualmente son construidos -o desconstruidos - por los medios: estos distorsionan la realidad (prensa); influyen en opiniones; modelan ideas de la gente en relación al proceso político y los problemas que éste debe tratar (determinan la agenda); y modifican funciones de habla y lenguaje (De Fleur y Ball-Rokeach, 1994: 335 a 348).

La contribución de las comunicaciones a nuestro sistema de significados compartidos es la vez compleja y profunda:

En este sentido, las funciones de los medios en cuanto a modificar el comportamiento del público son de largo alcance, sutiles y acumulativas. Además, en nuestra sociedad, los medios están tan entrelazados con otras formas de comunicación que es casi imposible aislar y examinar sus efectos separadamente (De Fleur y Ball-Rokeach, 1994: 348).

Concluyen:

Cuando las ciencias sociales especializadas se separaron de la filosofía, continuaron la investigación sobre la comprensión, mediante el estudio de la construcción del significado en el lenguaje, la cultura, la interacción simbólica y los schemata de la memoria. Hoy en día, estos esfuerzos se han visto complementados por el estudio de las comunicaciones de masas en su búsqueda de nuevos caminos en los que la realidad mediada proporcione una base para la construcción de significados (De Fleur y Ball-Rokeach, 1994: 348).

\section{Medios y clima cognoscitivo y de aprendizaje}

J. M. Pérez indica que para comprender la generación de sentido en la sociedad mediática debemos profundizar en el análisis de los aspectos semiológicos de la comunicación, no sólo en los lingüísticos. Señala que son los medios de comunicación y las relaciones con las nuevas fuentes de saber cada vez más dispersas, y no las escuelas ni los centros educativos tradicionales, "los que se están convirtiendo en el ámbito privilegiado de la transmisión del saber actual y en los urdidores de esa nueva racionalidad social -que bebe, sin duda, de muchas fuentes, pero sobre todo de una: del nuevo entramado industrial-financiero que impulsa el consumismo" (Pérez, 2000: 43).

Los media, su crecimiento continuo y su perenne ocupación del espacio-tiempo social, han venido a configurar un nuevo clima cognoscitivo y del aprendizaje $y$, sobre todo, un nuevo territorio que la escuela no puede ya acotar -y que, a veces, parece limitarse a denunciar-. Las generaciones jóvenes se han educado e instruido en ese presente extendido -que denominamos moda y actualidad- de los medios de comunicación. Han aprendido sus valores a través de ellos, y se han forjado niveles de aspiración y modelos de identificación que tienen que ver, sobre todo, con los que les ofrecen el mundo del cine, la televisión y el periodismo. La 
probabilidad de que estos valores y pautas de comportamiento coincidan con los de la escuela empieza a ser remota; incluso en algunas ocasiones se presentan evidentes síntomas de una divergencia profunda (Pérez, 2000: 43).

Advierte que está surgiendo un nuevo escenario que, dominado por los media y las comunicaciones, se está encargando de generar la mayoría de los aprendizajes socialmente relevantes: "En este contexto, no podemos dejar de reconocer la influencia que está teniendo en este proceso la extensión de la ideología neoliberal que, en forma de pensamiento único, pretende llevar incluso al terreno del conocimiento, las ideas y la cultura el imperativo exclusio del modelo de mercado libérrimo" (Pérez, 2000: 45).

Enlista las características del sistema escolar tradicional que empiezan a tambalearse en la sociedad de la información:

1. La escuela ya no es la depositaria del saber 0 , al menos, no lo es del saber socialmente relevante.

2. Las escuelas tampoco son los ámbitos privilegiados de transmisión de la educación.

3. La escuela es, tal vez, la institución más eficaz para la enseñanza de la lectoescritura, pero está quedándose atrás hoy en día en la promoción de la nueva alfabetización de la sociedad de la información: la del lenguaje audiovisual y de la informática.

4. En este contexto, los profesores ya no son considerados los maestros que atesoraban todas las habilidades y sabidurías.

5. Las escuelas ya no disponen de los únicos instrumentos para la producción y sistematización del saber.

6. La escuela ya no es la fuente de la racionalidad que funda o explica el orden social.

7. La escuela se ha tornado, además, un elemento poco práctico: conecta difícilmente con la acción social.

8. La escuela está perdiendo a marchas forzadas el poder que le había conferido el sistema social tradicional (Pérez, 2000: 45 a 48).

Nos encontramos, concluye, "con una escuela descentrada de sus funciones tradicionales que difícilmente encuentra su lugar en el mundo moderno del saber".

En un fenómeno sin precedentes históricos, asistimos a mutaciones profundísimas en la organización, estructura y funcionamiento de los diversos sistemas lingüísticos y comunicativos que componen la esfera de la inteligencia colectiva. Sin ninguna concesión a la retórica, nos hallamos ante una auténtica revolución en los sistemas de inteligencia cultural y lingüística (Pérez, 2000: 88).

Estamos asistiendo a un cambio cualitativo en las condiciones lingüísticas y semiológicas de la especia humana:

Hoy nos encontramos en una situación psicológica y lingüística particular: un cerebro filogenéticamente estructurado a un ritmo de cambio pausado y progresivo se encuentra, a finales del siglo $X X$, sometido a una tensión de cambio inaudita. En su entorno, están alterándose bruscamente las condiciones sensoriales y perceptivas, los sistemas sígnicos y simbólicos, las condiciones de comunicación y los sistemas de interpretación del mundo (Pérez, 2000: 89).

Este fenómeno que caracteriza la innovación específica de nuestra época puede describirse apelando a un cuádruple cambio:

a) Multiplicación y complicación creciente de los usos lingüísticos más variados. 
b) Convergencia e hibridación constante de unos lenguajes con otros hasta crear nuevas semióticas de tipo sincrético.

c) Ampliación y multiplicación de los sistemas de codificación, procesamiento y tratamiento de la información lingüística que hasta hace relativamente poco operaban exclusivamente con los recursos autónomos del cerebro interno biológico.

d) Transformación radical de las condiciones de enunciación lingüística y semiológica que han alterado de modo sustancial los entornos comunicativos y han cambiado las condiciones en que se produce el sentido (Pérez, 2000: 92).

Vivimos 'sitiados' por el "asalto constante de lo icónico, no se trata ya de la resurrección de una imagen de tipo tradicional, sino de la aparición de otro espécimen de imágenes y de sistemas icónicos que están cobrando vida a nuestro alrededor y transforman nuestras percepciones" (Pérez, 2000: 93).

Cualquier niño y casi cualquier adulto de hoy en día en casi todo el planeta es asediado diariamente por infinidad de situaciones de comunicación en que el lenguaje dominante no es el escrito y ni siquiera el verbal. Consume casi tres o cuatro horas de televisión al día, que combina con una atención casi neurótica por la música moderna. Asume cientos de miles de imágenes publicitarias. Se mueve entre lenguajes muy absorbentes como el diseño de objetos e interiores, los motivos de la moda y los ruidos de un espacio urbano saturado. Nos movemos además en situaciones de comunicación que han descartado lo concreto, lo local y personal, y se construyen a través de complejos telemáticos, telepresencias y virtualidades varias (Pérez, 2000: 95).

Indica que las capacidades lingüísticas y comunicativas que desarrollamos en el actual contexto mediático tienen poco que ver con las que se enseñan en las escuelas y centro de enseñanza (Pérez, 2000: 96). Subraya que es necesario afirmar la existencia de una capacidad semiótica general que debería centrar los esfuerzos didácticos. Al respecto propone desarrollar un nuevo concepto de 'competencia comunicativa': complementar la preocupación por los contenidos y las formas con un análisis mediático. "Porque el sentido surge y se realiza siempre en una situación mediática precisa y de ella depende en gran parte", conjuntando tipos de signos diversos (verbales, corporales, icónicos, gráficos, visuales, cinéticos, simbólicos, etc.) (Pérez, 2000: 97, 98 y 100). El análisis mediático no puede pasar por alto la fisicidad del medio, su realidad material:

Un medio de comunicación, en su entidad más real, ahorma el comportamiento del comunicador y del receptor. La televisión, por ejemplo, no es sólo transmisión de imágenes; es un dispositivo que sujeta al individuo delante de la pantalla, que le impone una cierta inmovilidad corporal, que potencia unos sentidos en detrimento de otros. No podemos pasar por alto, pues, que las diversas tecnologías de la información están potenciando la absorción del movimiento corporal por parte de las pantallas... A algunos les parecerá que esto tiene poco que ver con el sentido, pero quienes dispongan de una visión más global convendrán que las pantallas son, hoy día, el germen de una especie de burbuja invisible que, no sólo ampara la transmisión de información, sino que está organizando y pautando la acción social. Esta burbuja espectatorial creciente no es sólo consecuencia del lenguaje de las nuevas pantallas; es, también, condición básica de su misma existencia (Pérez, 2000: 100 y 101). 


\section{Análisis}

Como hemos visto, los medios ocupan un papel central en la conformación cultural de la sociedad contemporánea. La gestión del desarrollo sostenible de los asentamientos humanos contempla dentro de su dimensión cultural promover una conciencia y sensibilidad ambiental (una cultura ambiental o ecológica). Es necesario identificar cómo se propone generar esa cultura y de manera especial el papel conferido a los medios de comunicación en dicha gestión. Se revisarán los siguientes documentos:

- Declaración de Estocolmo sobre el Medio Humano (1972)

- Plan de Acción para el Medio Humano (1972)

- Declaración de Vancouver sobre los Asentamientos Humanos (1976)

- Plan de Acción para los Asentamientos Humanos (1976)

- Declaración de Río sobre el Medio Ambiente y el Desarrollo (1992)

- Agenda 21 (1992)

- Declaración de Estambul sobre los Asentamientos Humanos (1996)

- Plan de Acción Mundial del Programa de Hábitat (1996)

- Programa para Continuar con la Instrumentación de la Agenda 21 (1997)

- Declaración sobre las Ciudades y Otros Asentamientos Humanos en el Nuevo Milenio (2001).

Todos las Declaraciones, Planes y Programas tienen una conexión entre sí, no surgen de manera independiente o desconociendo lo propuesto con anterioridad. Se considera relevante analizar todos los documentos y no sólo los más recientes (redactados los últimos diez años) para identificar la lógica que ha operado durante tres décadas en la promoción del mejoramiento del medio humano y natural.

\section{Declaración de Estocolmo sobre el Medio Humano}

La Declaración de Estocolmo fue emitida en junio de 1972 en la Conferencia de las Naciones Unidas sobre el Medio Humano, celebrada en Estocolmo, Suecia. Consta de 26 Principios. Con relación a nuestro interés de investigación, el Principio 19 señala:

\section{Principio 19}

Es indispensable una labor de educación en cuestiones ambientales, dirigida tanto a las generaciones jóvenes como a los adultos y que preste la debida atención al sector de la población menos privilegiado, para ensanchar las bases de una opinión pública bien informada y de una conducta de los individuos, de las empresas y de las colectividades inspirada en el sentido de su responsabilidad en cuanto a la protección y mejoramiento del medio en toda su dimensión humana. Es también esencial que los medios de comunicación de masas eviten contribuir al deterioro del medio humano y difundan, por el contrario, información de carácter educativo sobre la necesidad de protegerlo y mejorarlo, a fin de que el hombre pueda desarrollarse en todos los aspectos.

Se subraya la necesidad de contar con programas de educación sobre temas ambientales; se indica que los medios de comunicación no deben contribuir al deterioro ambiental, sino difundir información de carácter educativo.

\section{Plan de Acción para el Medio Humano}

El Plan de Acción para el Medio Humano fue emitido en junio de 1972 en la Conferencia de las Naciones Unidas sobre el Medio Humano, celebrada en Estocolmo, Suecia. Consta de 109 recomendaciones divididas en 5 secciones (Anexo 2). Se analizó la cuarta sección: Aspectos educacionales, informativos, sociales y culturales de las cuestiones relativas al medio (Recomendaciones 95 a 101). Se transcriben los parágrafos en los que se encontró relación con nuestro interés de investigación: 


\section{Recomendación 95}

Se recomienda que el Secretario General tome las disposiciones necesarias a fin de que el sistema de las Naciones Unidas:

a) Proporcione a los países que lo soliciten la asistencia técnica y financiera necesaria para preparar informes nacionales sobre el medio, establecer sistemas de vigilancia de la evolución del medio desde el punto de vista social y cultural y, en particular, preparar programas sociales, educativos y culturales en el plano nacional.

Se recomienda preparar programas educativos y culturales a nivel nacional sobre el medio ambiente.

\section{Recomendación 96}

1. Se recomienda que el Secretario General, los organismos del sistema de las Naciones Unidas, en particular la Organización de las Naciones Unidas para la Educación, la Ciencia y la Cultura y las demás instituciones internacionales interesadas, tras consultarse y de común acuerdo, adopten las disposiciones necesarias a fin de establecer un programa internacional de educación sobre el medio, de enfoque interdisciplinario y con carácter escolar y extraescolar, que abarque todos los niveles de la enseñanza y se dirija al público en general, especialmente al ciudadano corriente que vive en las zonas rurales y urbanas, al joven y al adulto indistintamente, con miras a enseñarle las medidas sencillas que, dentro de sus posibilidades, pueda tomar para ordenar y controlar su medio. Para apoyar tal acción se necesitará un programa de cooperación y asistencia financiera y técnica, teniendo en cuenta las prioridades convenidas conforme a los recursos disponibles. Este programa debería constar, entre otras cosas de:

e) La preparación y ensayo de materiales y métodos nuevos para todos los tipos y grados de enseñanza sobre el medio.

Se recomienda establecer un programa internacional de educación sobre el medio ambiente con fines prácticos (ordenación y control) tanto de carácter escolar como extraescolar considerando todos los niveles de enseñanza y aspectos logísticos, pedagógicos, temáticos.

\section{Recomendación 97}

1. Se recomienda que el Secretario General adopte las disposiciones necesarias a fin de:

a) Establecer un programa de información destinado a suscitar el interés de los particulares por el medio humano y a lograr la participación del público en su ordenación y control. Tal programa recurrirá a los medios de información pública tradicionales y contemporáneos, teniendo en cuenta las peculiaridades nacionales. Además, deberá prever los medios de estimular la participación activa de los ciudadanos y despertar el interés y lograr la contribución de las organizaciones no gubernamentales en la salvaguardia y el mejoramiento del medio.

2. Se recomienda también que el Secretario General y las instituciones de desarrollo adopten las disposiciones necesarias para utilizar y adaptar ciertos programas internacionales de desarrollo, siempre que esto no lleve consigo un retraso en la ejecución de esos programas, con miras a mejorar la difusión de la información y a reforzar las actividades comunitarias en lo que se refiere a los problemas del medio, en particular entre los pueblos oprimidos y menos favorecidos de la Tierra.

Se recomienda establecer un programa de información utilizando los medios para suscitar el interés popular y lograr la participación de los dudadanos y ONGs; y mejorar la difusión de la información para reforzar las actividades comunitarias. 


\section{Declaración de Vancouver sobre los Asentamientos Humanos}

La Declaración de Vancouver fue emitida en junio de 1976 en la Conferencia de las Naciones Unidas sobre los Asentamientos Humanos (Hábitat I), celebrada en Vancouver, Canadá. Consta 33 parágrafos. Ninguno tiene relación con nuestro interés de investigación.

\section{Plan de Acción para los Asentamientos Humanos}

El Plan de Acción para los Asentamientos Humanos fue suscrito en junio de 1976 en la I Conferencia de las Naciones Unidas sobre los Asentamientos Humanos (Hábitat I), celebrada en Vancouver, Canadá. Consta de 64 recomendaciones generales divididas en 6 secciones (Anexo 2); el análisis se concentró en las secciones E: Participación pública; y F: Instituciones y gestión. Dentro de estas secciones se destacan las siguientes recomendaciones:

\section{Public Participation. Preamble}

9. Public participation implies not only efforts to convey information, but also a very important effort of education and formation to allow both specialist and public participation to play a determining role in evaluating the economic, technical and administrative consequences of the measures under consideration.

Se requiere información y programas de educación para lograr la participación profesional y popular.

\section{Recommendation E.3 Two-way flow}

a) Public participation does not mean simply the mobilization or people to implement the independent decisions of governments and professionals; participation requires listening and response in both directions.

b) TO BE EFFECTIVE, PUBLIC PARTICIPATION REQUIRES THE FREE FLOW OF INFORMATION AMONG ALL PARTIES CONCERNED AND SHOULD BE BASED ON MUTUAL UNDERSTANDING, TRUST AND EDUCATION.

C) This may be achieved through:

i) Legislation to stimulate public participation and to provide wide accessibility to public information;

iii) Information and possibly legal aid services to inform the citizen of legal rights and duties in relation to human settlement issues as well as to provide legal assistance;

v) Wide use of mass media to provide a forum for citizen participation and public debate.

Para que la participación sea efectiva se recomienda garantizar legalmente el acceso a la información pública, as í como informar específicamente sobre derechos y deberes relacionados con temas de asentamientos humanos. Los medios deben ser utilizados ampliamente como un foro para el debate público y la participación ciudadana.

\section{Recommendation E.5 New forms of participation}

a) Of all human endeavours, public participation is the one which can least afford to be isolated from current trends and changes in society, in so far as these effect the relationships between the governing and the governed, the professional and the laymen, the strong and the weak.

b) PUBLIC PARTICIPATION MUST RESPOND TO BOTH NEWLY EMERGING NEEDS OF SOCIETY AND TO EXISTING SOCIAL, ECONOMIC AND CULTURAL NEEDS. THE PEOPLE AND THEIR GOVERNMENTS SHOULD ESTABLISH MECHANISMS FOR POPULAR PARTICIPATION THAT CONTRIBUTE TO DEVELOPING AWARENESS OF PEOPLE'S ROLE IN TRANSFORMING SOCIETY.

c) Areas for special attention include: 
i) Establishment, especially in rapidly expanding urban areas, of effective channels of communication between the people and all levels of government, as well as mechanisms for enabling people to attain full control and influence in the formulation and implementation of policy for the development of human settlements.

Para que la gente sea consciente de su papel en la transformación de la sociedad se recomienda aumentar su influencia estableciendo mecanismos de comunicación con el gobierno.

\begin{abstract}
Recommendation E. 6 Mobilizing resources
a) Public participation is a human right, a political duty and an instrument essential for national development, especially under conditions of resource scarcity; unless their participation is encouraged by the appropriate political, economic and social institutions, people cannot identify with the decisions which affect their daily lives. b) PUBLIC PARTICIPATION ELICITED ON A SCALE COMMENSURATE WITH THE PROBLEMS OF HUMAN SETTLEMENTS, SHOULD INFLUENCE ALL DECISIONS CONCERNING MANAGEMENT OF HUMAN SETTLEMENTS AND SHOULD FOCUS ON THE APPLICATION OF RESOURCES TO IMPROVEMENT OF THE STANDARD OF LIVING AND THE QUALITY OF LIFE.

C) Efforts should be directed in particular to:

vi) Mechanisms to promote participation by the people in production, distribution, and consumption, and programmes for employment, job training, and distribution of consumer goods.
\end{abstract}

Se recomienda desarrollar programas de capacitación que promuevan la participación relacionada con el mejoramiento de la calidad y los estándares de vida.

\title{
Recommendation F.6 Management of settlements
}

a) Too often, conditions in human settlements deteriorate rapidly. Among other things, this results from poor management, and under-utilization of existing resources, facilities and infrastructure. Such deficiencies are avoidable.

b) SETTLEMENTS MUST BE IMPROVED BY RESPONSIVE AND IMAGINATIVE MANAGEMENT OF ALL RESOURCES.

C) This should be done by:

vi) Providing information and incentives for inhabitants to maintain and improve their dwellings and surroundings.

Se recomienda proporcionar información para conservar y mejorar las viviendas y sus alrededores.

\section{Declaración de Río sobre el Medio Ambiente y el Desarrollo}

La Declaración de Río fue emitida en junio de 1992 en la Conferencia de las Naciones Unidas sobre el Medio Ambiente y el Desarrollo (Cumbre de la Tierra), celebrada en Río de Janeiro, Brasil. Consta de 27 Principios. Con relación a nuestro interés de investigación, el Principio 10 señala:

\section{Principio 10}

El mejor modo de tratar las cuestiones ambientales es con la participación de todos los ciudadanos interesados, en el nivel que corresponda. En el plano nacional, toda persona deberá tener acceso adecuado a la información sobre el medio ambiente de que dispongan las autoridades públicas, incluida la información sobre los materiales y las actividades que encierran peligro en sus comunidades, así como la oportunidad de participar en los procesos de adopción de decisiones. Los Estados deberán facilitar y fomentar la sensibilización y la participación de la 
población poniendo la información a disposición de todos. Deberá proporcionarse acceso efectivo a los procedimientos judiciales y administrativos, entre éstos el resarcimiento de daños y los recursos pertinentes.

Se indica la necesidad de fomentar la sensibilización y facilitar la participación de la población a través de la difusión de información.

\section{Agenda 21}

La Agenda 21 fue suscrita en junio de 1992 en la Conferencia de las Naciones Unidas sobre el Medio Ambiente y el Desarrollo (Cumbre de la Tierra), celebrada en Río de Janeiro, Brasil. Consta de 40 capítulos divididos en 4 secciones (Anexo 2). El análisis se concentró en los capítulos 4: Evolución de las modalidades de consumo; 7: Fomento del desarrollo sostenible de los asentamientos humanos; 8: Dimensión ambiental en la toma de decisiones; en todos los capítulos de la Sección III: Fortalecimiento del papel de los grupos sociales (capítulos 23 a 32); y en el capítulo 36: Educación, la capacitación y la toma de conciencia.

\section{Sección I: Dimensiones sociales y económicas}

\section{Capítulo 4: Evolución de las modalidades de consumo}

4.8. En principio, los países deben guiarse por los siguientes objetivos básicos en sus esfuerzos por tratar la cuestión del consumo y estilos de vida en el contexto del desarrollo y el medio ambiente:

a) Todos los países deben procurar promover modalidades de consumo sostenibles.

Se recomienda promover modalidades de consumo sostenibles.

4.19. Al mismo tiempo, la sociedad necesita desarrollar medios efectivos para tratar los problemas relativos a la eliminación de cantidades cada vez mayores de materiales y productos de desecho. Los gobiernos, junto con el sector industrial, las unidades familiares y el público en general, deben realizar esfuerzos concertados para reducir la generación de desechos y productos de desecho mediante:

a) El fomento del reciclaje a nivel del procesamiento industrial y del consumidor.

Se recomienda fomentar el reciclaje en el proceso productivo y a nivel familiar y personal.

4.21. Los gobiernos, en colaboración con el sector industrial y otros grupos interesados, deben alentar la difusión del etiquetado con indicaciones ecológicas y otros programas de información sobre productos que tienen relación con el medio ambiente, a fin de que el consumidor pueda hacer una selección fundamentada.

Se recomienda desarrollar programas de información sobre productos 'ecológicos'.

4.22. Los gobiernos también deberían fomentar la aparición de un público consumidor informado y ayudar a las personas y a las unidades familiares a hacer una selección ecológicamente fundamentada mediante:

a) El suministro de información sobre las consecuencias que tienen las opciones y los comportamientos en materia de consumo, a fin de promover la demanda y el uso de productos ecológicamente racionales.

b) La creación de conciencia en los consumidores respecto del efecto que los productos tienen sobre la salud y el medio ambiente, valiendo de leyes de protección del consumidor y del etiquetado con indicaciones ecológicas.

c) El fomento de programas expresamente orientados al consumidor, como el reciclaje y los sistemas de pago y reembolso de depósitos por envases. 
Se recomienda difundir información sobre el problema del consumo; concientizar a los consumidores sobre los efectos de la producción; y fomentar programas de reciclaje a nivel de los consumidores.

4.24. Sin el estímulo de los precios y las indicaciones del mercado que den a conocer claramente al productor y al consumidor el costo ecológico que representa el consumo de energía, materiales y recursos naturales y la generación de desechos, al parecer no será probable lograr en el futuro próximo cambios significativos en las modalidades de consumo y producción.

Se recomienda proporcionar información sobre el costo ecológico de los sistemas de producción y modalidades de consumo.

4.26. Los gobiernos y las organizaciones del sector privado deberían fomentar la adopción de actitudes más positivas hacia el consumo sostenible mediante la educación, los programas de toma de conciencia del público y otros medios como la publicidad positiva de productos y servicios que utilizaran tecnologías ecológicamente racionales o fomentaran modalidades sostenibles de producción y consumo.

Mediante la educación, programas de concientización pública y la publicidad de productos 'ecológicos' se recomienda fomentar otras actitudes de consumo.

4.27. El interés primordial de este programa reside en los cambios de las modalidades no sostenibles de consumo y producción y en los valores que promuevan modalidades de consumo y estilos de vida sostenibles. Se requieren los esfuerzos combinados de los gobiernos, los consumidores y los productores. Debe prestarse especial atención a la importante función que desempeñan las mujeres y los hogares como consumidores y a las repercusiones que puede tener sobre la economía su poder adquisitivo combinado.

Se señala la impo rtancia de la dimensión valórica (cambio valórico) en la promoción de estilos de vida sostenibles.

\section{Capítulo 7: Fomento del desarrollo sostenible de los asentamientos humanos}

7.20. Todas las ciudades, especialmente las que se caracterizan por graves problemas de desarrollo sostenible, deberían, de conformidad con las leyes, normas y reglamentos nacionales, formular y fortalecer programas destinados a abordar esos problemas y a orientar su desarrollo en forma sostenible. Ya existen algunas iniciativas internacionales para apoyar esos esfuerzos en el Programa de ciudades sostenibles de Hábitat y el Programa de ciudades sanas de la MOSA, que deberían intensificarse. Deberían fortalecerse y coordinarse otras iniciativas del Banco Mundial, los bancos regionales de desarrollo, los organismos bilaterales y otras partes comprometidas, en particular los representantes internacionales y nacionales de autoridades locales. Las diversas ciudades, según los casos, deberían:

a) Institucionalizar un criterio de participación para el desarrollo urbano sostenible sobre la base de un dialogo constante entre los participantes en el desarrollo urbano (el sector público, el sector privado y las comunidades), especialmente las mujeres y las poblaciones indígenas.

b) Mejorar el medio ambiente urbano promoviendo la organización social y la conciencia sobre el medio ambiente mediante la participación de comunidades locales en la determinación de los servicios públicos necesarios, la dotación de infraestructura urbana, el mejoramiento de los servicios públicos y la protección o rehabilitación de viejas edificaciones, recintos históricos y otros elementos 
culturales. Además, deben activarse los programas de 'trabajos verdes' con el objeto de crear actividades autosostenidas de desarrollo humano y oportunidades de empleo en los sectores estructurado y no estructurado para residentes urbanos de bajos ingresos.

g) Preparar a grupos comunitarios, organizaciones no gubernamentales y particulares para que asuman la autoridad y responsabilidad de ordenar y mejorar su medio inmediato mediante los instrumentos, las técnicas y los criterios de participación que abarca el concepto de atención del medio ambiente.

Se recomienda institucionalizar el diálogo entre gobierno, empresas y sociedad civil; promover la conciencia ambiental mediante la participación comunitaria en la determinación de sus necesidades en términos de infraestructura y conservación de patrimonio cultural; y capacitar a organizaciones y comunidades.

7.51. El enfoque amplio del cesarrollo de los asentamientos humanos debería incluir la promoción de un desarrollo de energía sostenible en todos los países, de la siguiente manera:

a) Los países en desarrollo, en particular, deberían:

iv) Ejecutar programas de información y capacitación destinados a fabricantes y usuarios a fin de propiciar las técnicas que economicen energía y los artefactos que utilicen energía en forma eficiente.

Se recomienda ejecutar programas de información y capacitación para un uso sostenible de la energía.

7.54. A fin de aumentar el nivel técnico de las instituciones y de los profesionales que se ocupan de los servicios de energía y del transporte, todos los países deberían, según procediera:

b) Aumentar la conciencia del público sobre las consecuencias ambientales del transporte y los viajes mediante campanas en los medios de información y apoyo a las iniciativas de organizaciones no gubernamentales y de la comunidad que promuevan la utilización de transporte no motorizado, el transporte colectivo en automóvil y el mejoramiento de las medidas de seguridad en el trafico.

Se recomienda desarrollar campañas en los medios de información para aumentar la conciencia del público sobre las consecuencias ambientales del transporte.

7.60. Para promover una 'cultura de seguridad' en todos los países, especialmente los propensos a los desastres, se deberían realizar las siguientes actividades:

b) Organizar campanas nacionales para crear conciencia de la importancia de la seguridad en el plano nacional y local, utilizando todos los medios de difusión disponibles, y convertir esos conocimientos en información que el público en general y las poblaciones directamente expuestas a los peligros puedan comprender fácilmente.

Se recomienda organizar campañas utilizando los medios para crear conciencia de la importancia de desarrollar una 'cultura de seguridad' (prevención de desastres).

7.77. En cada una de las áreas de programas del presente capítulo se han incluido actividades concretas de desarrollo de los recursos humanos y de aumento de la capacidad. Sin embargo, a título más general, habría que adoptar nuevas medidas para fortalecer esas actividades. A fin de lograr ese objetivo, todos los países deberían adoptar las siguientes medidas:

d) Proporcionar asistencia directa al desarrollo de los asentamientos humanos a nivel de la comunidad, entre otras cosas mediante: 
i) El fortalecimiento y la promoción de programas de movilización social y creación de conciencia de las posibilidades de las mujeres y los jóvenes en las actividades relativas a los asentamientos humanos.

Se recomienda promover y fortalecer programas de movilización y creación de conciencia relacionados con los temas de género y la juventud.

7.80. Habría que combinar los dos tipos de capacitación, la axadémica y la no académica, en los programas de desarrollo de los recursos humanos y aumento de la capacidad, y convendría utilizar métodos de enseñanza orientados hacia el usuario, materiales de enseñanza actualizados $y$ sistemas modernos de comunicación audiovisual.

Se recomienda utilizar en los programas de capacitación tecnologías de comunicación audiovisual.

\section{Capítulo 8: La dimensión ambiental en la toma de decisiones}

8.4. La necesidad principal consiste en integrar los procesos de adopción de decisiones sobre el medio ambiente y el desarrollo. Para ello, los gobiernos deberían efectuar un examen nacional y, en los casos en que procediera, mejorar los procesos de adopción de decisiones de manera que se logre la integración gradual de las cuestiones económicas, sociales y del medio ambiente en un proceso de desarrollo económicamente eficiente, socialmente equitativo $y$ responsable y ecológicamente racional. Los países determinaran sus propias prioridades de conformidad con sus planes, políticas y programas nacionales para las actividades siguientes:

f) Asegurar el acceso del público a la información pertinente, facilitando la recepción de opiniones del público y permitiendo su participación efectiva.

Se recomienda difundir información y crear mecanismos que faciliten la participación y la expresión de opiniones.

8.11. Los países, en cooperación con instituciones y grupos nacionales, medios de comunicación y la comunidad internacional, deberían adoptar medidas para que la opinión pública en general y los círculos especializados cobraran conciencia de la importancia de tener simultáneamente en cuenta el medio ambiente $y$ el desarrollo, y deberían establecer mecanismos para facilitar el intercambio directo de información y de opiniones con el público. Se debería poner especial empeño en destacar las responsabilidades y las posibles aportaciones de los diferentes grupos sociales.

Se recomienda que los medios de comunicación cooperen con los gobiernos para concientizar al público sobre la problemática ambiental y los temas del desarrollo, estableciendo asimismo mecanismos de información y participación.

8.16. El objetivo general consiste en promover, de conformidad con las condiciones particulares de cada país, la integración de las políticas de medio ambiente y desarrollo mediante la formulación de leyes, reglamentos, instrumentos y mecanismos coercitivos adecuados a nivel nacional, estatal, provincial y local. Habida cuenta de que los países determinaran sus propias prioridades de conformidad con sus necesidades y planes, políticas y programas nacionales $y$, en los casos en que proceda, regionales, se proponen los objetivos siguientes:

a) Difundir información sobre innovaciones jurídicas y reglamentarias eficaces en la esfera del medio ambiente y el desarrollo, con inclusión de instrumentos de carácter coercitivo e incentivos al cumplimiento, para fomentar su mayor utilización y su adopción en los planos nacional, estatal, provincial y local.

Se recomienda difundir información sobre innovaciones jurídicas y reglamentarias. 
8.17. Los gobiernos, con la asistencia, según procediera, de las organizaciones internacionales competentes, deberían evaluar periódicamente sus leyes y reglamentos y los mecanismos institucionales conexos de carácter institucional y administrativo que existan en los planos nacional, estatal, local y municipal, en relación con el medio ambiente y el desarrollo sostenible, con miras a hacerlos eficaces en la práctica. Los programas que se formulen a tal efecto deberían incluir la promoción de la conciencia del público, la preparación y distribución de material de orientación y la capacitación especializada, mediante cursos prácticos, seminarios, programas de educación y conferencias de funcionarios públicos encargados de formular, aplicar, vigilar $y$ hacer cumplir las leyes $y$ los reglamentos.

Se recomienda promover la conciencia pública sobre leyes, reglamentos y mecanismos institucionales mediante cursos, programas de educación y conferencias.

8.48. Los gobiernos deberían alentar a las empresas a que:

a) Proporcionaran información ecológica pertinente presentando informes claros y detallados a accionistas, acreedores, empleados, autoridades gubernamentales, consumidores y público en general.

Se recomienda a las empresas presentar información a los consumidores y al público en general.

\section{Sección III: Fortalecimiento del papel de los grupos sociales Capítulo 23: Preámbulo}

23.2. Uno de los requisitos fundamentales para alcanzar el desarrollo sostenible es la amplia participación de la opinión pública en la adopción de decisiones. Además, en el contexto más concreto del medio ambiente y el desarrollo, se ha hecho evidente la necesidad de emplear nuevas formas de participación. Se trata de la necesidad de que las personas, los grupos y las organizaciones participen en los procedimientos de evaluación del impacto ambiental, conozcan el mecanismo de adopción de decisiones y participen en él, sobre todo cuando exista la posibilidad de que esas decisiones afecten a las comunidades donde viven $y$ trabajan. Toda persona, grupo u organización debería tener acceso a la información relativa al medio ambiente y el desarrollo con que contaran las autoridades nacionales, incluso a la información acerca de productos y actividades que tuvieran consecuencias importantes para el medio ambiente o hubiera probabilidades de que las tuvieran, así como a la información sobre las medidas de protección del medio ambiente.

Se recomienda que los gobiernos permitan el acceso a la información que poseean relacionada con el medio ambiente y el desarrollo.

\section{Capítulo 24: Mujer y desarrollo sostenible}

24.3. Los gobiernos deberían dedicarse activamente a poner en práctica lo siguiente:

h) Programas para aumentar el conocimiento de los consumidores y la participación activa de la mujer que hagan hincapié en su papel decisivo en la realización de los cambios necesarios para reducir o eliminar patrones de consumo y producción insostenibles, en particular en los países industrializados, a fin de promover las inversiones en actividades productivas ecológicamente racionales e inducir un desarrollo industrial mesurado desde los puntos de vista social y del medio ambiente.

i) Programas para eliminar imágenes, ideas estereotipadas y actitudes negativas y prejuicios que persisten en contra de la mujer mediante cambios en las 
modalidades de socialización, los medios de comunicación, los anuncios y la enseñanza académica y no académica.

Se recomienda desarrollar programas para aumentar el conocimiento de los consumidores, especialmente de las mujeres; cambiar modalidades de socialización, los mensajes de los medios de comunicación, la publicidad y la enseñanza para eliminar prejuicios y actitudes contrarios a la mujer.

24.8. Los países, con la colaboración de las instituciones académicas y las investigadoras locales, deberían crear bases de datos y sistemas de información y análisis de políticas y realizar investigaciones orientadas hacia la acción con miras a la participación, en que se tuvieran en cuenta las diferencias entre sexos, sobre los aspectos siguientes:

g) Programas para crear centros de capacitación, investigaciones e información en las zonas rurales y urbanas de países desarrollados y países en desarrollo para dar a conocer a la mujer las tecnologías ecológicamente racionales.

Se recomienda crear programas para capacitar a la mujer sobre tecnologías ecológicas.

24.11. EI UNIFEM debería celebrar consultas periódicas con los donantes, en colaboración con el UNICEF, con miras a promover programas y proyectos operacionales relacionados con el desarrollo sostenible que aumentaran la participación de la mujer, sobre todo la de bajos ingresos, en el desarrollo sostenible y en la adopción de decisiones. EI PNUD debería establecer un centro de coordinación sobre medio ambiente y desarrollo para la mujer en cada una de las oficinas de sus representantes residentes a fin de suministrar información y promover el intercambio de experiencias e información en esas esferas. Los órganos del sistema de las Naciones Unidas, los gobiernos y las organizaciones no gubernamentales que participen en el seguimiento de las actividades a que de lugar la Conferencia y en la ejecución de la Agenda 21 deberían velar por que las consideraciones relativas a la diferencia entre sexos se tuvieran plenamente en cuenta en todas las políticas, programas y actividades.

Se recomienda promover programas para aumentar la participación de la mujer y eliminar la discriminación de género.

\section{Capítulo 25: La infancia y la juventud en el desarrollo sostenible}

25.4. Cada país debería instituir, en consulta con sus círculos de jóvenes, un proceso para promover el dialogo entre los círculos de jóvenes y el gobierno a todos los niveles y establecer mecanismos que permitieran el acceso de los jóvenes a la información y que les aseguraran la posibilidad de presentar sus opiniones sobre las decisiones oficiales, incluso sobre la ejecución de la Agenda 21.

Se recomienda facilitar la participación de los jóvenes y permitir su acceso a la información.

25.9. Los gobiernos, con arreglo a sus estrategias, deberían tomar medidas para: d) Velar por el acceso de todos los jóvenes a todos los tipos de educación, cuando proceda, estableciendo otros sistemas de enseñanza; velar por que la educación refleje las necesidades económicas y sociales de la juventud e incorpore los conceptos de sensibilización ecológica y desarrollo sostenible en todos los programas de enseñanza; y ampliar la formación profesional, aplicando métodos innovadores encaminados a aumentar los conocimientos prácticos, como son las actividades de exploración relacionadas con el medio ambiente.

f) Establecer grupos de trabajo formados por jóvenes y por organizaciones juveniles no gubernamentales para elaborar programas de enseñanza $y$ 
sensibilización concretamente orientados hacia la población juvenil acerca de cuestiones de importancia decisiva para la juventud. Estos grupos de trabajo debería emplear los métodos de la enseñanza académica y no académica para llegar al mayor número de personas. Los medios de información nacionales y locales, las organizaciones no gubernamentales, los círculos económicos y otras organizaciones deberían prestar su concurso a estos grupos de trabajo.

Se recomienda incorporar conceptos de sensibilización ecológica y desarrollo sostenible en todos los programas de enseñanza; sensibilizar sobre cuestiones decisivas para la juventud empleando métodos no académicos, los medios de información deberían colaborar.

25.14. Los gobiernos deberían tomar medidas decisivas para:

d) Ampliar las oportunidades de instrucción para la infancia y la juventud, así como la educación encaminada a crear conciencia de la responsabilidad respecto del medio ambiente y el desarrollo, y prestar atención prioritaria a la educación de las niñas.

e) Movilizar a las comunidades por medio de las escuelas y los centros de salud locales de manera que los niños y sus padres sean objetivos centrales efectivos cuando se trate de sensibilizar a las comunidades acerca de las cuestiones del medio ambiente.

Se recomienda ampliar la educación encaminada a crear conciencia ambiental y de los temas del desarrollo con enfoque de género; sensibilizar a las comunidades por medio de las escuelas y los centros de salud locales.

\section{Capítulo 26: Poblaciones indígenas y sus comunidades}

26.9. Los organismos de desarrollo internacional y los gobiernos deberían destinar recursos financieros y de otra índole a la educación y la capacitación de las poblaciones indígenas y sus comunidades para que pudieran lograr su desarrollo autónomo sostenible, contribuir al desarrollo sostenible y equitativo a nivel nacional y participar en él. Se debería prestar atención especial al fortalecimiento del papel de la mujer indígena.

Se recomienda crear programas de educación y capacitación para los grupos indígenas.

\section{Capítulo 27: Organizaciones no gubernamentales}

27.9. El sistema de las Naciones Unidas, así como los organismos internacionales de financiación $y$ desarrollo, $y$ todas las organizaciones $y$ los foros intergubernamentales deberían adoptar, en consulta con las organizaciones no gubernamentales, medidas encaminadas a:

g) Dar acceso a las organizaciones no gubernamentales a datos e información exactos y oportunos con el objeto de fomentar la eficacia de sus programas y actividades y de sus funciones de apoyo del desarrollo sostenible.

Se recomienda proporcionar información oficial a las ONGs.

\section{Capítulo 28: Autoridades locales y Agenda 21}

28.3. Cada autoridad local debería iniciar un dialogo con sus ciudadanos, organizaciones locales y empresas privadas y aprobar una 'Agenda 21 local'. Mediante la celebración de consultas y la promoción de un consenso, las autoridades locales recibirían aportes de la ciudadanía y las organizaciones cívicas, empresariales e industriales locales y obtendrían la información necesaria para formular las mejores estrategias. El proceso de consultas aumentaría la conciencia de los hogares respecto de las cuestiones relativas al desarrollo sostenible. Los programas, las políticas, la legislación y las reglamentaciones de las autoridades locales para lograr los objetivos de la Agenda 21 se evaluarían y 
modificarían sobra la base de los programas locales aprobados en el marco de la Agenda 21. También se podrían emplear estrategias para apoyar propuestas encaminadas a obtener financiación local, nacional, regional e internacional.

Se recomienda que los gobiernos locales celebren consultas públicas y promuevan el consenso para aumentar la conciencia de la ciudadanía.

\begin{abstract}
Capítulo 29: Los trabajadores y sus sindicatos
29.12. Los trabajadores y sus representantes deberían tener derecho a que se les impartiera suficiente capacitación para incrementar su conciencia ambiental, proteger su salud y velar por su seguridad y mejorar su bienestar económico y social. La capacitación debería proporcionarles los conocimientos necesarios para fomentar modos de vida sostenibles y mejorar el medio laboral. Los sindicatos, los patronos, los gobiernos y los organismos internacionales deberían cooperar en la evaluación de las necesidades de capacitación dentro de sus respectivas esferas de actividad. Los trabajadores y sus representantes deberían participar en la formulación y la ejecución de los programas de capacitación para los trabajadores organizados por los patronos y gobiernos.
\end{abstract}

Se recomienda capacitar a los trabajadores para aumentar su conciencia ambiental y fomentar modos de vida sostenibles.

\title{
Capítulo 30: Comercio e industria
}

30.10. Debería alentarse al comercio y a la industria, incluidas las empresas transnacionales, a:

b) Proceder a la adopción de códigos de conducta que fomenten prácticas ambientales idóneas, como la Carta de las Empresas para un Desarrollo Sostenible, de la Cámara de Comercio Internacional, y la iniciativa del cuidado responsable adoptada por la industria química, e informar sobre su aplicación.

Se recomienda alentar al comercio y a las industria para que adopten códigos de conducta que fomenten prácticas 'ecológicas'.

30.14. Las asociaciones industriales y comerciales deberían alentar a cada una de las empresas a que aplicaran programas para aumentar la conciencia y la responsabilidad ecológica a todos los niveles, con objeto de que todas las empresas mejoraran su actuación en lo que afectara al medio ambiente, sobre la base de prácticas de gestión internacionalmente aceptadas.

Se recomienda que las asociaciones industriales y comerciales inviten a las empresas a concientizar a sus empleados (a todos los niveles) sobre cuestiones ambientales para mejorar su funcionamiento.

\section{Capítulo 31: Comunidad científica y tecnológica}

31.8. El aumento de la conciencia ética en lo relativo a la adopción de decisiones que afecten al medio ambiente y al desarrollo debería contribuir a establecer prioridades pertinentes para el mantenimiento y perfeccionamiento de los sistemas sustentadores de la vida, for la propia razón de ser de dichos sistemas, y, en consecuencia, garantizar que las sociedades presentes y futuras valorasen de manera adecuada el funcionamiento de los procesos naturales viables. Por consiguiente, el fortalecimiento de los códigos de conducta y las directrices para la comunidad científica y tecnológica aumentaría la conciencia ambiental y contribuiría al desarrollo sostenible. Ayudaría asimismo a que se tuviera en mayor estima y consideración a la comunidad científica y tecnológica y facilitaría la 'responsabilidad' de la ciencia y la tecnología. 
Se recomienda aumentar la conciencia ética de los científicos para tomar decisiones ambientalmente adecuadas.

31.10. Se podrían realizar las actividades siguientes:

b) Establecimiento y fortalecimiento de grupos nacionales de asesoramiento sobre ética ecológica y del desarrollo, a fin de crear un marco de valores común para la comunidad dedicada a la ciencia y la tecnología y toda la sociedad, y promover un dialogo constante.

c) Ampliación de la educación y capacitación relativas a la ética ecológica y del desarrollo para integrar esos objetivos en los programas de educación y las prioridades de investigación.

Se recomienda establecer grupos nacionales de asesoramiento sobre ética ecológica y del desarrollo para crear un marco de valores común para toda la sociedad; integrar esta ética en los programas de educación.

31.12. Deberían elaborarse, con la participación de la comunidad científica y tecnológica, códigos de conducta y directrices, incluso sobre principios apropiados, para uso de aquella en sus actividades de investigación y en la ejecución de programas encaminados a alcanzar el desarrollo sostenible. La UNESCO podría dirigir la aplicación de esas actividades con la colaboración de otros organismos de las Naciones Unidas y de organizaciones intergubernamentales y no gubernamentales.

Se recomienda elaborar códigos de conducta y directrices para el uso apropiado de tecnología.

\section{Capítulo 32: Agricultores}

No se hace referencia a nuestro interés de investigación.

\section{Sección IV: Medios para la puesta en práctica}

\section{Capítulo 36: Educación, la capacitación y la toma de conciencia}

36.3. Debe reconocerse que la educación -incluida la enseñanza académica- la toma de conciencia del público y la capacitación, configuran un proceso que permite que los seres humanos y las sociedades desarrollen plenamente su capacidad latente. La educación es de importancia crítica para promover el desarrollo sostenible y aumentar la capacidad de las poblaciones para abordar cuestiones ambientales y de desarrollo. Si bien la educación básica sirve de fundamento para la educación en materia de medio ambiente y desarrollo, esta última debe incorporarse como parte fundamental del aprendizaje. Tanto la educación académica como la no académica son indispensables para modificar las actitudes de las personas de manera que éstas tengan la capacidad de evaluar los problemas del desarrollo sostenible y abordarlos. La educación es igualmente fundamental para adquirir conciencia, valores $y$ actitudes, técnicas $y$ comportamiento ecológicos y éticos en consonancia con el desarrollo sostenible y que favorezcan la participación pública efectiva en el proceso de adopción de decisiones. Para ser eficaz, la educación en materia de medio ambiente y desarrollo debe ocuparse de la dinámica del medio físico/biológico y del medio socioeconómico y el desarrollo humano (que podría comprender el desarrollo espiritual), integrarse en todas las disciplinas y utilizar métodos académicos y no académicos y medios efectivos de comunicación.

Se indica que la educación es de importancia crítica para promover el desarrollo sostenible y aumentar capacidad de las poblaciones para abordar cuestiones ambientales y de desarrollo, es indispensable para modificar las atitudes de las personas (desarrollar conciencia crítica) y es fundamental para adquirir conciencia, valores, actitudes, técnicas y comportamientos en 
consonancia con el desarrollo sostenible; la educación ambiental y sobre el desarrollo debe utilizar medios efectivos de comunicación.

36.5. Reconociendo que los países y las organizaciones regionales e internacionales determinarán sus propias prioridades y plazos de aplicación de conformidad con sus necesidades, políticas y programas, se proponen las actividades siguientes:

b) Los gobiernos deberían procurar actualizar o preparar estrategias destinadas a la integración en los próximos tres años del medio ambiente y el desarrollo como tema interdisciplinario en la enseñanza a todos los niveles. Esa actividad debería realizarse en cooperación con todos los sectores de la sociedad. En las estrategias se deberían formular políticas y actividades y determinar necesidades, costos, medios y programas de ejecución, evaluación y examen. Se debería iniciar un examen exhaustivo de los programas de estudios a fin de establecer un enfoque multidisciplinario, que abarque las cuestiones ambientales y de desarrollo y sus aspectos y vinculaciones socioculturales y demográficos. Se deberían respetar debidamente las necesidades definidas por la comunidad y los diversos sistemas de conocimientos, incluidas la ciencia y la sensibilidad cultural y social.

c) Se exhorta a los países a que establezcan organismos consultivos nacionales para la coordinación de la educación ecológica o mesas redondas representativas de diversos intereses, tales como el medio ambiente, el desarrollo, la educación, la mujer y otros, $y$ de las organizaciones no gubernamentales, con el fin de estimular la colaboración, ayudar a movilizar recursos y crear una fuente de información y de coordinación para la participación internacional. Esos órganos contribuirían a movilizar a los distintos grupos de población y comunidades y facilitar sus actividades para que evalúen sus propias necesidades y adquieran las técnicas necesarias para elaborar y poner en práctica sus propias iniciativas en materia de medio ambiente y desarrollo.

e) Las autoridades competentes deberían velar por que todas las escuelas recibieran ayuda en la elaboración de los planes de trabajo sobre actividades ambientales, con la participación de los estudiantes y del personal. Las escuelas deberían estimular la participación de los escolares en estudios locales y regionales sobre salud ambiental, incluso el agua potable, el saneamiento y la alimentación y los ecosistemas, y en las actividades pertinentes, vinculando ese tipo de estudios con los servicios e investigaciones realizados en parques nacionales, reservas de fauna y flora, sitios de valor ecológico protegidos, etc.

h) Es necesario fortalecer, en un plazo de cinco años, el intercambio de información mediante el mejoramiento de la tecnología y los medios necesarios para promover la educación sobre el medio ambiente y el desarrollo y la conciencia del público. Los países deberían cooperar entre sí y con los diversos sectores sociales y grupos de población para preparar instrumentos educacionales que abarquen cuestiones e iniciativas regionales en materia de medio ambiente y desarrollo, utilizando materiales y recursos de aprendizaje adaptados a sus propias necesidades.

k) Los países deberían facilitar y promover las actividades de enseñanza no académica en los planos local, regional y nacional mediante la cooperación y el apoyo de los esfuerzos de los instructores no académicos y otras organizaciones con base en la comunidad. Los órganos competentes del sistema de las Naciones Unidas, en colaboración con las organizaciones no gubernamentales, deberían fomentar el desarrollo de una red internacional para el logro de los objetivos mundiales en materia de educación. En los foros públicos y académicos de los planos nacional y local se deberían examinar las cuestiones ambientales y de desarrollo y sugerir opciones sostenibles a los encargados de formular políticas.

l) Las autoridades educacionales, con la colaboración apropiada de las organizaciones no gubernamentales, incluidas las organizaciones de mujeres y de poblaciones indígenas, deberían promover todo tipo de programas de educación 
de adultos para fomentar la educación permanente en materia de medio ambiente y desarrollo, utilizando como base de operaciones las escuelas primarias $y$ secundarias y centrándose en los problemas locales. Dichas autoridades y la industria deberían estimular a las escuelas de comercio, industria y agricultura para que incluyeran temas de esa naturaleza en sus programas de estudios. El sector empresarial podría incluir el desarrollo sostenible en sus programas de enseñanza y capacitación. En los programas de posgrado se deberían incluir cursos especialmente concebidos para capacitar a los encargados de adoptar decisiones.

m) Los gobiernos y las autoridades educacionales deberían promover las oportunidades para la mujer en esferas no tradicionales y eliminar de los programas de estudios los prejuicios en cuanto a las diferencias entre los sexos. Esto podría lograrse mejorando las oportunidades de inscripción, la incorporación de la mujer, como estudiante o instructora, en programas avanzados, la reforma de las disposiciones de ingreso y las normas de dotación de personal docente y la creación de incentivos para establecer servicios de guarderías infantiles, según proceda. Se debería dar prioridad a la educación de las adolescentes y a programas de alfabetización de la mujer.

n) Los gobiernos deberían garantizar, mediante legislación si fuera necesario, el derecho de las poblaciones indígenas a que su experiencia y comprensión acerca del desarrollo sostenible desempeñaran una función en la educación y capacitación.

Se recomienda establecer un enfoque multidisciplinario en la educación integrando el problema del medio ambiente y del desarrollo; crear organismos consultivos sobre educación ecológica y otros temas relevantes a nivel nacional para movilizar y apoyar a la población; estimular educación y participación ambiental con aplicación regional y local; promover la educación y la conciencia utilizando pedagogía adecuada a cada región; facilitar educación no formal; fomentar educación permanente enfocada a los adultos sobre temas ambientales y de desarrollo; y eliminar de bs programas de estudios prejuicios de género; incorporar saberes de las poblaciones indígenas en los programas de educación y capacitación.

36.7. Teniendo en cuenta la situación de cada país, se podría prestar más apoyo a las actividades de educación, capacitación y toma de conciencia relacionadas con el medio ambiente y el desarrollo, en los casos en que procediera, mediante la adopción de medidas como las siguientes:

h) Utilización de los medios de difusión para fines de enseñanza en forma gratuita o semigratuita.

Se recomienda solicitar el apoyo de los medios de difusión para el desarrollo de programas de educación, capacitación y toma de conciencia (donar tiempo).

36.8. Aún hay muy poca conciencia de la interrelación existente entre todas las actividades humanas y el medio ambiente, debido a la insuficiencia o la inexactitud de la información. Los países en desarrollo en particular carecen de la tecnología y los especialistas pertinentes. Es necesario sensibilizar al público sobre los problemas del medio ambiente y el desarrollo, hacerlo participar en su solución y fomentar un sentido de responsabilidad personal respecto del medio ambiente y una mayor motivación y dedicación respecto del desarrollo sostenible.

Se recomienda sensibilizar al público; se señala a la desinformación como causa de la poca conciencia.

36.10. Reconociendo que los países y las organizaciones regionales e internacionales determinarán sus propias prioridades y plazos de aplicación de 
Kevista Mad. No.J. Septiembre 2UU1. Departamento de Antropologia. Unıversidad de C'hıle http://sociales.uchile.cl/publicaciones/mad/05/paper06.htm

conformidad con sus necesidades, políticas y programas, se proponen las siguientes actividades:

a) Los países deberían fortalecer los organismos consultivos existentes 0 establecer otros nuevos de información pública en materia de medio ambiente y desarrollo y coordinar las actividades con las Naciones Unidas, las organizaciones no gubernamentales y los medios de difusión más importantes. Deberían fomentar la participación del público en los debates sobre políticas y evaluaciones ambientales. Los gobiernos deberían facilitar y apoyar también la formación de redes nacionales y locales de información mediante los sistemas ya existentes.

b) El sistema de las Naciones Unidas debería mejorar sus medios de divulgación mediante un examen de sus actividades de educación y sensibilización del público para promover una mayor participación y coordinación de todas las partes del sistema, especialmente de sus organismos de información y sus operaciones nacionales y regionales. Deberían hacerse estudios sistemáticos de los resultados de las campañas de difusión, teniendo presentes las necesidades y las contribuciones de grupos determinados de la comunidad.

c) Debería alentarse a los países y a las organizaciones regionales, según proceda, a que proporcionaran servicios de información pública sobre el medio ambiente y el desarrollo para aumentar la conciencia de todos los grupos, del sector privado y en particular de los encargados de adoptar decisiones.

d) Los países deberían estimular a los establecimientos educacionales en todos los sectores, especialmente en el sector terciario, para que aportaran una mayor contribución a la toma de conciencia del público. Los materiales didácticos de todo tipo y para todo público deberían basarse en la mejor información científica disponible, que incluyera tanto las ciencias naturales como las ciencias sociales y del comportamiento, y que tuviera en cuenta consideraciones estéticas y éticas.

e) Los países y el sistema de las Naciones Unidas deberían promover una relación de cooperación con los medios de información, los grupos de teatro popular y las industrias del espectáculo y de la publicidad, iniciando debates para movilizar su experiencia en la empresa de influir en el comportamiento y en las pautas de consumo del público, y haciendo uso abundante de sus métodos. Esa colaboración también aumentaría la participación activa del público en el debate sobre el medio ambiente. EI UNICEF debería elaborar material orientado hacia los niños para los medios de información, a manera de instrumento didáctico, a fin de establecer una estrecha colaboración entre el sector de la información pública extraescolar y el programa de estudios de la enseñanza primaria. La UNESCO, el UNEP y las universidades deberían enriquecer los programas de estudios anteriores al servicio para periodistas con temas relacionados con el medio ambiente y el desarrollo.

f) Los países, en colaboración con la comunidad científica, deberían establecer medios de emplear la tecnología moderna de las comunicaciones para llegar al público de manera eficaz. Las autoridades nacionales y locales de educación y los organismos pertinentes de las Naciones Unidas deberían incrementar, según proceda la utilización de medios audiovisuales, especialmente en las zonas rurales, mediante el empleo de unidades de servicios móviles y la producción de programas de radio y televisión para los países en desarrollo que fomenten la participación local, empleen métodos interactivos e integren los métodos más modernos y los medios de difusión populares.

i) Los países y el sistema de las Naciones Unidas deberían aumentar su interacción e incluir, según proceda, a las poblaciones indígenas en la ordenación, la planificación y el desarrollo de su medio ambiente local, y deberían fomentar la difusión de conocimientos tradicionales y de adquisición social mediante medios basados en las costumbres locales, especialmente en las zonas rurales, integrando esos esfuerzos con los medios de difusión electrónicos, en los casos en que ello sea posible. 
Se recomienda establecer organismos de información pública considerando a los medios de difusión más importantes; mejorar los medios de divulgación de las Naciones Unidas; proporcionar información para aumentar la conciencia de todos los grupos, empresarios y funcionarios públicos; estimular a las instituciones de educación, especialmente las universidades, para que contribuyan a aumentar la conciencia del público; promover relación con los medios de información, industrias del espectáculo y la publicidad para aprovechar su experiencia con el fin de influir en el comportamiento y en las pautas de consumo del público, haciendo uso de sus métodos; emplear la tecnología de comunicación, medios audiovisuales, programas de radio y televisión, medios populares de difusión para fomentar la participación local en los países en desarrollo; e integrar medios electrónicos en las zonas rurales y comunidades indígenas.

36.12. La capacitación es uno de los instrumentos más importantes para desarrollar los recursos humanos y facilitar la transición hacia un mundo más sostenible. La capacitación debería apuntar a impartir conocimientos que ayuden a conseguir empleo y a participar en actividades relativas al medio ambiente y el desarrollo. Al mismo tiempo, los programas de capacitación deberían fomentar una mayor conciencia de los asuntos relativos al medio ambiente y el desarrollo como proceso de aprendizaje dual.

Se recomienda crear programas de capacitación que fomenten una mayor conciencia.

36.15. Se alienta a las asociaciones profesionales nacionales a que elaboren y examinen sus códigos deontológicos y de conducta para fortalecer las vinculaciones y la dedicación a la causa del medio ambiente. Los elementos de capacitación y desarrollo personal de los programas patrocinados por los órganos profesionales deberían permitir la incorporación de conocimientos e información sobre la aplicación del desarrollo sostenible en todas las etapas de la adopción de decisiones y políticas.

Se recomienda alentar a las asociaciones profesionales para que revisen o elaboren sus códigos de conducta y desarrollen programas de capacitación considerando la cuestión ambiental.

36.22. Los países deberían incrementar las posibilidades de acceso, análisis y utilización eficaz de la información y los conocimiento disponibles sobre el medio ambiente y el desarrollo. Se deberían reforzar los programas de capacitación especiales existentes con el fin de apoyar las necesidades de información de grupos especiales. Se deberían evaluar los efectos de esos programas en la productividad, la salud, la seguridad y el empleo. Se deberían crear sistemas nacionales y regionales de información sobre el mercado de trabajo relacionado con el medio ambiente, sistemas que proporcionarían en forma constante datos sobre las oportunidades de capacitación y de trabajo en la materia. Se deberían preparar y actualizar guías sobre los recursos de capacitación en medio ambiente y desarrollo que contengan información sobre programas de capacitación, programas de estudios, métodos y resultados de las evaluaciones en los planos nacional, regional e internacional.

Se recomienda incrementar la difusión y las posibilidades de uso de información.

\section{Declaración de Estambul sobre los Asentamientos Humanos}

La Declaración de Estambul fue emitida en junio de 1996 en la II Conferencia de las Naciones Unidas sobre los Asentamientos Humanos (Hábitat II), celebrada en Estambul, Turquía. Consta de 15 parágrafos. Ninguno tiene relación con nuestro interés de investigación.

Plan de Acción Mundial del Programa de Hábitat 
El Plan de Acción Mundial del Programa de Hábitat fue suscrito en junio de 1996 en la II Conferencia de las Naciones Unidas sobre los Asentamientos Humanos (Hábitat II), celebrada en Estambul, Turquía. El Plan de Acción Mundial corresponde al Capítulo IV del Programa de Hábitat. Está estructurado en 6 Secciones (Anexo 2). Se transcriben los parágrafos que tienen relación con nuestro interés de investigación.

\section{Desarrollo sostenible de los asentamientos humanos en un mundo en} proceso de urbanización

3. Desarrollo social: erradicación de la pobreza, creación de empleo productivo e integración social

117. Para fomentar la integración social, los gobiernos a los niveles apropiados, incluidas las autoridades locales, reconociendo la importancia de las contribuciones voluntarias, y en estrecha cooperación con organizaciones no gubernamentales, organizaciones comunitarias, el sector cooperativo y fundaciones públicas y privadas, deben:

d) estimular, en cooperación con las partes interesadas pertinentes, comprendidos los padres en lo que respecta a la educación de sus hijos, la elaboración de programas escolares, programas de educación y centros comunitarios para desarrollar la comprensión y la cooperación entre miembros de diversas culturas.

Se recomienda elaborar programas escolares y de educación y estimular la creación de centros comunitarios para desarrollar la tolerancia cultural.

119. Con el fin de fomentar una planificación y gestión de los asentamientos humanos en que se tengan en cuenta las necesidades de uno y otro sexo, los gobiernos a los niveles apropiados, incluidas las autoridades locales, $y$ en colaboración con grupos de mujeres y otras partes interesadas, deben:

e) promover cambios de actitudes, estructuras, políticas, leyes y otras prácticas relativas a los sexos a fin de eliminar todos los obstáculos a la dignidad humana y la igualdad en la familia y la sociedad, y promover la participación plena y en condiciones de igualdad de las mujeres y los hombres, comprendidas las personas con discapacidad, en la vida social, económica y política, entre otras cosas en la formulación, la aplicación y el seguimiento de políticas y programas públicos.

Se recomienda promover cambios culturales y estructurales (leyes, políticas) con relación a la mujer y los discapacitados.

120. Con el fin de desarrollar plenamente el potencial de los jóvenes y de prepararlos para asumir un papel responsable en el desarrollo de los asentamientos humanos, los gobiernos, a los niveles apropiados, incluidas las autoridades locales, y en asociación con el sector privado, organizaciones juveniles no gubernamentales $y$ otras organizaciones no gubernamentales $y$ organizaciones de base comunitaria, deben:

e) utilizar la educación, tanto académica como no académica, y las actividades y los programas de formación profesional, promover -en colaboración con la juventud-programas de empleo y de desarrollo de las aptitudes profesionales que refuercen la capacidad de la juventud para participar plenamente en los procesos sociales, económicos y políticos de los asentamientos humanos;

g) estimular las campañas de sensibilización y otras medidas preparadas $y$ aplicadas por la juventud, a fin de fomentar la apreciación por los jóvenes del patrimonio histórico, natural, religioso, espiritual y cultural y su toma de conciencia de los valores ecológicos y de las consecuencias ambientales de sus pautas de producción, consumo, de comportamiento y éticas, especialmente las relacionadas con una vivienda adecuada para todos y con el desarrollo sostenible de los asentamientos humanos. 
Se recomienda promover programas educativos y de capacitación orientados a los jóvenes para que participen en la gestión de los asentamientos humanos; y estimular las campañas de sensibilización preparadas por la juventud.

\section{Población y desarrollo sostenible de los asentamientos humanos}

127. A fin de atender a las cuestiones relativas a la población que afectan a los asentamientos humanos $y$ de integrar plenamente las preocupaciones demográficas en las políticas sobre asentamientos humanos, los gobiernos a los niveles apropiados, incluidas las autoridades locales y otras partes interesadas, deben:

c) fomentar la toma de conciencia, el conocimiento y la comprensión de los efectos de los cambios demográficos y de las variables de desarrollo en los asentamientos humanos a todos los niveles de la sociedad mediante campañas de información pública, y actividades de comunicación que se centren en la importancia y pertinencia de las cuestiones relacionadas con la población y en las medidas responsables necesarias para resolver esas cuestiones, en particular la salud, la planificación familiar y los modelos de consumo y producción compatibles con un desarrollo sostenible.

Se recomienda fomentar la toma de conciencia con relación a la cuestión demográfica y las variables del desarrollo y el ambiente en los asentamientos humanos a través de campañas de información y actividades de comunicación.

\section{Asentamientos humanos ambientalmente sostenibles, sanos y habitables 135. La habitabilidad de las zonas edificadas es muy importante para la calidad de la vida en los asentamientos humanos. La calidad de la vida supone la existencia de los atributos que permiten atender a aspiraciones diversificadas y crecientes que van más allá de la satisfacción de las necesidades básicas de los ciudadanos. La habitabilidad guarda relación con las características y cualidades de espacio, entorno social y medio ambiente que contribuyen singularmente a dar a la gente una sensación de bienestar personal y colectivo e infundirle la satisfacción de residir en un asentamiento determinado. Las aspiraciones a la habitabilidad varían de un lugar a otro y evolucionan y cambian con el tiempo. También difieren según las poblaciones que integran las comunidades. Por lo tanto, las condiciones para que haya asentamientos humanos habitables presuponen una democracia que funcione y en la que estén institucionalizados los procesos y mecanismos de participación, dedicación cívica y fomento de la capacidad.}

Se indica que la habitabilidad requiere de la participación, el civismo y la capacitación institucionalizadas.

137. A fin de mejorar las condiciones ambientales y reducir los desechos industriales y domésticos y otras amenazas para la salud en los asentamientos humanos, los gobiernos a los niveles apropiados, en asociación con todas las partes interesadas, deben:

j) sensibilizar a la opinión pública acerca de las cuestiones ambientales y promover en las comunidades el conocimiento, las actitudes y las prácticas necesarias para el desarrollo sostenible de los asentamientos humanos.

Se recomienda sensibilizar y capacitar a la gente.

\section{Utilización sostenible de la energía}

146. A fin de fomentar la utilización eficiente y sostenible de la energía, los gobiernos a los niveles apropiados, en asociación con el sector privado, las 
organizaciones no gubernamentales, las organizaciones de base comunitaria y los grupos de consumidores, deben, según proceda:

i) alentar y promover campañas de educación pública y de información a través de los medios de difusión para fomentar el reciclado, el reaprovechamiento y un consumo de energía menor.

Se recomienda utilizar los medios de difusión para informar y educar al público sobre el uso eficiente de la energía.

\begin{abstract}
9. Mejorar las economías urbanas
156. Las ciudades han servido tradicionalmente de centros económicos y se han convertido en los principales proveedores de servicios. Como motores del crecimiento económico y del desarrollo, funcionan en el marco de una red de actividades económicas de apoyo situadas en las zonas periurbanas y rurales circundantes. Por esta razón, también es necesario tomar medidas concretas para establecer y mantener sistemas de transporte, de información y de comunicación eficientes y económicos, así como enlaces con otros centros urbanos y con las zonas rurales y para tratar de establecer modalidades de desarrollo razonablemente equilibradas, tanto desde el punto de vista geográfico como desde el económico. Los rápidos cambios en la tecnología de producción y en las pautas de comercio y consumo ocasionarán cambios en las estructuras espaciales urbanas que habrá que tener en cuenta, cualquiera que sea su naturaleza.
\end{abstract}

Se recomienda invertir en sistemas de información y comunicación.

\title{
10. Desarrollo equilibrado de los asentamientos en las zonas rurales
}

167. Los gobiernos a los niveles apropiados, incluidas las autoridades locales, al establecer las políticas de desarrollo y ordenación regional sostenible, deben:

a) promover programas de educación y capacitación y establecer procedimientos para la plena participación de las poblaciones rurales e indígenas en la fijación de prioridades para un desarrollo regional equilibrado y ecológicamente viable.

Se recomienda promover programas de educación y capacitación para lograr la participación en las zonas rurales.

169. A fin de promover un desarrollo urbano y rural equilibrado y basado en el apoyo mutuo es preciso adoptar un planteamiento integrado. Para lograr ese objetivo, los gobiernos a los niveles apropiados, incluidas las autoridades locales, con el apoyo de las instituciones internacionales y regionales competentes, deben: b) facilitar la creación de una infraestructura eficaz de distribución y comunicación para el intercambio de información, mano de obra, bienes, servicios y capital entre las zonas urbanas y las rurales.

Se recomienda crear infraestructura que permita el intercambio de información entre zonas rurales y urbanas.

\section{Fomento de la capacidad y desarrollo institucional 3. Participación popular y compromiso cívico}

182. A fin de alentar y apoyar la participación, el compromiso cívico y el cumplimiento de las responsabilidades gubernamentales, los gobiernos nacionales, las organizaciones de la sociedad civil y las autoridades locales, según proceda, deben poner en funcionamiento marcos institucionales y jurídicos que faciliten y hagan posible la participación amplia de todos los ciudadanos en la adopción de decisiones y la aplicación y vigilancia de estrategias, políticas y programas de asentamientos humanos; estos marcos institucionales y jurídicos deben estar dirigidos específicamente, entre otras cosas, a: 
e) realizar programas de educación cívica, utilizando todos los medios de comunicación, y campañas de educación e información, a fin de fomentar el espíritu cívico y promover el conocimiento de los derechos y responsabilidades cívicos y de los medios de ejercerlos, así como de las cuestiones del desarrollo económico sostenible y de la mejora de la calidad de vida.

q) promover la aplicación de nuevas tecnologías de información y de los medios de comunicación, incluidos los medios de comunicación locales, para facilitar el diálogo, intercambiar información, experiencias y prácticas pertinentes sobre asentamientos humanos y formar colaboraciones constructivas entre la sociedad civil y las personas encargadas de adoptar decisiones.

Se recomienda realizar programas de información y educación cívica utilizando los medios de comunicación; utilizar los medios (incluyendo nuevas tecnologías) para facilitar el diálogo, la participación, la información y la asociación.

\section{Información y comunicaciones \\ 190. Los recientes progresos en la tecnología informática y de las comunicaciones, junto con la liberalización del comercio y el libre flujo de capital a escala mundial, ocasionarán cambios radicales en los papeles y las funciones de las ciudades y en sus procesos de adopción de decisiones y asignación de recursos. Las sociedades que efectúen las inversiones necesarias en tecnología e infraestructura informática y habiliten a sus ciudadanos para que la utilicen eficazmente podrán lograr enormes aumentos de productividad en la industria y el comercio. Esta tecnología informática mejorada debe ser utilizada en forma óptima para preservar y compartir valores morales e impulsar y mejorar la educación, la capacitación y la sensibilización pública sobre cuestiones sociales, económicas y ambientales que afectan a la calidad de vida, y para que todas las partes y las comunidades interesadas puedan intercambiar información sobre las prácticas en materia de hábitat, incluidas las que defienden los derechos de los niños, de las mujeres $y$ de otros grupos desfavorecidos, en el contexto de una creciente urbanización.}

Se recomienda utilizar la tecnología informática para sensibilizar, educar, capacitar y facilitar el flujo de información.

191. A fin de mejorar la capacidad para aprovechar estas innovaciones con objeto de potenciar sus repercusiones para bien de todos, las administraciones a todos los niveles, incluidas las autoridades locales, deben, según proceda:

a) desarrollar, mejorar y mantener la infraestructura y la tecnología informática y alentar a todos los niveles de la administración, las instituciones públicas y las organizaciones de la sociedad civil, así como a las organizaciones de base comunitaria, a utilizarlas, y considerar las comunicaciones como parte integrante de la política de asentamientos humanos.

b) promover la capacitación de las principales instituciones en materia de utilización de la tecnología informática.

c) desarrollar métodos para compartir experiencias de iniciativas locales por medios electrónicos, como la Internet y redes y bibliotecas y para difundir información sobre las mejores prácticas, incluidas aquellas en que se recurre a políticas que tienen en cuenta las necesidades de uno y otro sexo.

d) aplicar programas que fomenten la utilización de bibliotecas y redes de comunicación públicas, sobre todo por parte de los niños, los jóvenes y las instituciones docentes.

e) facilitar el proceso de aprendizaje mediante la avulgación de experiencias, tanto fructíferas como fallidas, relacionadas con los asentamientos humanos, en los sectores gubernamental, público, privado y comunitario. 
f) fomentar políticas que permitan al público mayor acceso a servicios y tecnología informáticos, en particular mediante una amplia utilización de los medios de difusión.

h) fomentar el desarrollo de una programación de los medios de difusión nacionales y locales en que se reconozca la diversidad racial y cultural de las grandes ciudades y se promueva la comprensión de puntos de vista diferentes.

j) asegurar la competencia en el mercado y un amplio acceso público al suministro de la tecnología informática y de comunicaciones mediante una intervención pública en el mantenimiento del acceso a la tecnología informática $y$ de comunicaciones.

Se recomienda desarrollar, mejorar y mantener la tecnología informática y alentar su uso a todos los niveles; capacitar para el uso de la tecnología informática; utilizar los medios electrónicos para difundir información; fomentar el uso de bibliotecas y redes de comunicación públicas; divulgar experiencias; promover a través de los medios tradicionales el uso de la informática; fomentar programas en los medios que promuevan la tolerancia y reconozcan la diversidad existentes en las ciudades; y asegurar las condiciones políticas y mercantiles que permitan el acceso público a la tecnología informática y de comunicaciones.

\section{F. Aplicación y seguimiento}

3. Aplicación a nivel internacional

228. En el marco de su mandato y considerando la necesidad de centrarse en objetivos bien definidos y en cuestiones estratégicas, el Centro de las Naciones Unidas para los Asentamientos Humanos (Hábitat) deberá cumplir, entre otras, las funciones siguientes:

j) fomentar la utilización de tecnología audiovisual e informática en relación con los objetivos de vivienda adecuada y desarrollo sostenible de los asentamientos humanos.

Se recomienda fomentar el uso de la informática y la tecnología audiovisual para promover viviendas adecuadas y asentamientos sostenibles.

\section{Participación de las autoridades locales y de la sociedad civil, con inclusión del sector privado \\ 238. La contribución al desarrollo de las autoridades locales y de la sociedad civil, con inclusión del sector privado, puede mejorarse de la siguiente manera: \\ e) alentando a las instituciones educativas, los medios de comunicación y otras fuentes de información y opinión públicas para que presten especial atención a los problemas de desarrollo de los asentamientos humanos y faciliten un debate amplio y bien informado sobre políticas en toda la comunidad.}

Se recomienda alentar a las instituciones educativas y a los medios para que presten atención a los problemas de los asentamientos y faciliten el debate comunitario sobre las políticas correspondientes.

\section{Programa para Continuar con la Instrumentación de la Agenda 21}

El Programa para Continuar con la Instrumentación de la Agenda 21 fue suscrito en junio de 1997 por la Asamblea General de las Naciones Unidas durante la evaluación del progreso ambiental y social (Río+5) alcanzado desde la Conferencia de las Naciones Unidas sobre el Medio Ambiente y el Desarrollo. Está estructurado en 4 Capítulos (Anexo 2). Se destacan los siguientes parágrafos:

II. Assessment of progress made since the United Nations Conference on Environment and Development

12. The major groups have demonstrated what can be achieved by taking committed action, sharing resources and building consensus, reflecting grass-roots concern and involvement. The efforts of local authorities are making Agenda 21 
and the pursuit of sustainable development a reality at the local level through the implementation of 'local Agenda 21s' and other sustainable development programmes. Non-governmental organizations, educational institutions, the scientific community and the media have increased public awareness and discussion of the relations between environment and development in all countries. The involvement, role and responsibilities of business and industry, including transnational corporations, are important. Hundreds of small and large businesses have made 'green business' a new operating mode. Workers and trade unions have established partnerships with employers and communities to encourage sustainable development in the workplace. Farmer-led initiatives have resulted in improved agricultural practices contributing to sound resource management. Indigenous people have played an increasing role in addressing issues affecting their interests and particularly concerning their traditional knowledge and practices. Young people and women around the world have played a prominent role in galvanizing communities into recognizing their responsibilities to future generations. Nevertheless, more opportunities should be created for women to participate effectively in economic, social and political development as equal partners in all sectors of the economy.

Se indica que los medios han incrementando la conciencia y discusión de las relaciones entre el ambiente y el desarrollo.

\section{Implementation of Agenda 21 in areas requiring urgent action \\ A. Integration of economic, social and environmental objectives Changing consumption and production patterns}

28. Unsustainable patterns of production and consumption, particularly in the industrialized countries, are identified in Agenda 21 as the major cause of continued deterioration of the global environment. While unsustainable patterns in the industrialized countries continue to aggravate the threats to the environment, there remain huge difficulties for developing countries in meeting basic needs such as food, health care, shelter and education for people. All countries should strive to promote sustainable consumption patterns; developed countries should take the lead in achieving sustainable consumption patterns; developing countries should seek to achieve sustainable consumption patterns in their development process, guaranteeing the provision of basic needs for the poor, while avoiding those unsustainable patterns, particularly in industrialized countries, generally recognized as unduly hazardous to the environment, inefficient and wasteful, in their development processes. This requires enhanced technological and other assistance from industrialized countries. In the follow-up of the implementation of Agenda 21, the review of progress made in achieving sustainable consumption patterns should be given high priority. Consistent with Agenda 21, the development and further elaboration of national policies and strategies, particularly in industrialized countries, are needed to encourage changes in unsustainable consumption and production patterns, while strengthening, as appropriate, international approaches and policies that promote sustainable consumption patterns on the basis of the principle of common but differentiated responsibilities, applying the polluter pays principle, and encouraging producer responsibility and greater consumer awareness. Eco-efficiency, cost internalization and product policies are also important tools for making consumption and production patterns more sustainable. Actions in this area should focus on:

(h) Encouraging the media, advertising and marketing sectors to help shape sustainable consumption patterns.

(i) Improving the quality of information regarding the environmental impact of products and services and, to that end, encouraging the voluntary and transparent use of eco-labelling. 
(m) Giving balanced consideration to both the demand side and the supply side of the economy in matching environmental concerns and economic factors, which could encourage changes in the behaviour of consumers and producers. A number of policy options should be examined; they include regulatory instruments, economic and social incentives and disincentives, facilities and infrastructure, information, education, and technology development and dissemination.

Se recomienda promover la responsabilidad de los productores y la conciencia de los consumidores para lograr patrones de consumo sostenibles y motivar a los medios, el marketing y la publicidad para que ayuden a formar dichos patrones; y mejorar la calidad de la información relacionada con el impacto ambiental de productos y servicios; motivar cambios de actitud en los consumidores y los productores, y promover programas de información y educación.

\section{Means of implementation Transfer of environmentally sound technologies}

97. There is a need to further explore and enhance the potential of global electronic information and telecommunication networks. This would enable countries to choose among the available technological options that are most appropriate to their needs. In this respect, the international community should assist developing countries in enhancing their capacities.

Se recomienda aprovechar el potencial de las redes electrónicas y las redes de telecomunicación.

\section{Education and awareness}

105. Education increases human welfare, and is a decisive factor in enabling people to become productive and responsible members of society. A fundamental prerequisite for sustainable development is an adequately financed and effective educational system at all levels, particularly the primary and secondary levels, that is accessible to all and that augments both human capacity and well-being. The core themes of education for sustainability include lifelong learning, interdisciplinary education, partnerships, multicultural education and empowerment. Priority should be given to ensuring women's and girls' full and equal access to all levels of education and training. Special attention should also be paid to the training of teachers, youth leaders and other educators. Education should also be seen as a means of empowering youth and vulnerable and marginalized groups, including those in rural areas, through intergenerational partnerships and peer education. Even in countries with strong education systems, there is a need to reorient education, awareness and training so as to promote widespread public understanding, critical analysis and support for sustainable development. Education for a sustainable future should engage a wide spectrum of institutions and sectors, including but not limited to business/industry, international organizations, youth, professional organizations, non-governmental organizations, higher education, government, educators and foundations, to address the concepts and issues of sustainable development, as embodied throughout Agenda 21, and should include the preparation of sustainable development education plans and programmes, as emphasized in the work programme of the Commission on Sustainable Development on the subject adopted in 1996. The concept of education for a sustainable future will be further developed by the United Nations Educational, Scientific and Cultural Organization, in cooperation with others.

Se indica que la educación (primaria y secundaria) es un prerrequisito fundamental para el desarrollo sostenible; se recomienda desarrollar programas educativos reorientando conceptos, contenidos, enfoques y métodos con la participación de un amplio espectro de sectores e instituciones.

Information and tools for measuring progress 
112. A supportive environment needs to be established to enhance national capacities and capabilities for information collection, processing and dissemination, especially in developing countries, to facilitate public access to information on global environmental issues through appropriate means, including high-tech information and communication infrastructure related to the global environment, in the light of country-specific conditions, using, where available, such tools as geographic information systems and video transmission technology, including global mapping. In this regard, international cooperation is essential.

Se recomienda facilitar la difusión de información utilizando la infraestructura y los medios de comunicación e información de alta tecnología.

\section{Declaración sobre las Ciudades y Otros Asentamientos Humanos en el Nuevo Milenio}

La Declaración sobre las Ciudades y Otros Asentamientos Humanos en el Nuevo Milenio fue suscrita en junio de 2001 por la Asamblea General de las Naciones Unidas durante la evaluación del progreso en materia de hábitat (Estambul+5) alcanzado desde la II Conferencia de las Naciones Unidas sobre los Asentamientos Humanos. Está dividida en 4 Secciones (Anexo 2). Se destacan los siguientes parágrafos:

\section{Recognizing gaps and obstacles}

18. Note with concern that one of the basic obstacles to the implementation of the Habitat Agenda is the discrepancy between commitments made at Istanbul and the political will to fulfil them. We also acknowledge the gaps in both public information and awareness-raising as impediments.

Se reconocen como impedimentos para la instrumentación del Programa de Hábitat las carencias en información y el no aumento de la conciencia pública.

26. Recognize that there is unequal access to information and communication technologies, particularly in the developing countries, which has resulted in the inability of Governments and Habitat Agenda partners to make the best use of this resource in implementing the Habitat Agenda.

Se reconoce un acceso inequitativo a las tecnologías de información y comunicación particularmente en los países en desarrollo.

\section{Taking further actions}

32. Also resolve to promote changes in attitudes, structures, policies, laws and other practices relating to gender in order to eliminate all obstacles to human dignity and equality in family and society and to promote full and equal participation of women and men, inter alia, in the formulation, implementation and follow-up of public policies and programmes.

Se recomienda promover cambios de actitudes en lo relacionado al tema de género.

37. Resolve to raise awareness about human settlements challenges and solutions through full and open dissemination of information and commit ourselves to renew and foster political will at all levels.

Se recomienda aumentar la conciencia sobre los desafíos de los asentamientos humanos a través de la información y fomentar el cambio político.

38. Also resolve to empower the poor and vulnerable, inter alia through promoting greater security of tenure and enabling better access to information and good 
practices, including awareness of legal rights. We aim to develop specific policies for overcoming growing urban poverty.

Se recomienda proporcionar más información a los pobres y sectores más vulnerables.

\section{Resultados}

La educación (escolar y extraescolar), la capacitación y la difusión de información son las principales estrategias propuestas para generar una cultura de la sostenibilidad; se destaca asimismo la importancia de promover la participación. A los medios se les confiere el siguiente rol:

- Colaborarar en actividades de educación, capacitación y/o concientización y sensibilización (Agenda 21, parágrafos 4.26, 8.11, 24.3i, 25.9f, 36.7h, 36.10e, 36.10i; Programa de Hábitat, parágrafos 146i, 182e, 190, 191h; Programa para Continuar..., parágrafo 28h).

- Difundir información (Declaración de Estocolmo, principio 19; Plan de Acción para el Medio Humano, recomendación 97; Agenda 21, parágrafos 7.54, 7.60b, 8.11, 25.9f, 36.10a; Programa de Hábitat, parágrafos 182e, 191c, 191e, 228j; Programa para Continuar..., parágrafo 112).

- Realizar foros de debate público (Agenda 21, parágrafo 8.11; Plan de Acción para los Asentamientos Humanos, parágrafo E.3c-v; Programa de Hábitat, parágrafo 238e).

- Fomentar la participación (Plan de Acción para el Medio Humano, recomendación 97; Agenda 21, parágrafos 8.11, 36.10f; Programa de Hábitat, parágrafo, 182q).

La instituciones de educación son destacadas como los espacios en donde debe fundarse el cambio cultural (Agenda 21, parágrafos 25.14d, 36.3, 36.5c; Programa para Continuar..., parágrafo 105); asimismo, se subraya el papel de espacios con vocación pública, específicamente, centros de salud (Agenda 21, parágrafo 25.14d) y gobiernos locales (Agenda 21, parágrafo 28.3). Son los gobiernos nacionales los responsables de promover la cultura ambiental; los medios de comunicación deben apoyar las iniciativas diseñadas.

El impacto mediático con relación al consumo (una de las principales causas señalada por el UNEP del deterioro ambiental) es considerado en la Agenda 21 en los parágrafos 4.26 y 36.10e, y en el Programa para Continuar... parágrafo 28h; lo que se recomienda es realizar campañas en los medios que promuevan un consumo ecológicamente responsable, aprovechando la experiencia de los mismos medios.

\section{Conclusiones y recomendaciones}

Considerar el consumo de los habitantes de las zonas urbanas como una de las principales causas del deterioro ambiental global exige replantear las políticas instrumentadas para superar dicho deterioro. Así como es necesario fomentar el desarrollo ecoindustrial, el ordenamiento territorial y la planificación de asentamientos humanos con criterios ambientales aplicando mecanismos técnicos, financieros y normativos, es fundamental problematizar el papel del sujeto, específicamente, su modo de vida y pensamiento.

Bajo esta perspectiva cultural-ambiental el desafío es la formación de una personalidad ecológica un sujeto consciente del impacto ambiental y social que producen sus actividades; profundizando en lo ambiental, que internalice su huella ecológica ${ }^{12}$. Claudio Esteva (1993) indica que cada medio cultural produce sus líneas de conformación de la personalidad. El aspecto clave de la gestión de la sostenibilidad sería entonces la reproducción de líneas orientadoras de la conducta humana inspiradas en los valores del ecologismo. La revisión documental que hemos realizado nos ha permitido detectar que la estrategia recomendad a por las Naciones Unidas para reproducir

12 Superficie de tierra y agua biológicamente productivas que requiere un individuo (o una población) para obtener los recursos que demanda y para que se asimilen los desechos que genera -usando tecnología convencional. 
esta ideología es inadecuada, ya que considera a las instituciones educativas (educación escolar y extraescolar) como los órganos centrales en la formación valórica del sujeto, cuando hemos visto con Van Dijk, Sodré, De Fleur y Ball-Rokeach, y Pérez que los medios de comunicación las han desplazado; la estrategia se limita a solicitar la colaboración de los medios para fomentar el consumo de productos ecológicos, no analiza a fondo el problema del consumismo y la forma como los medios influyen en este fenómeno, por lo que carece de iniciativas para superar esta situación.

Sin descuidar la dimensión educativa a nivel escolar y extraescolar la política cultural ambiental debe reorientar su gestión, ampliarla: trabajar desde los medios. La reproducción de la ideología del ecologismo, o el fomento de la cultura ecológica o para la sostenibilidad, debe ser un fenómeno mediático, no sólo pedagógico e informativo. Ahora bien, Juan Luis Pintos (1994) indica que las ideologías sin determinados imaginarios que hagan creíbles los sistemas de racionalización legitimadora de los valores que proponen o son simplemente rechazadas por las mayorías o se mantienen en el puro campo de las ideas reconocidas como valiosas pero que no generan ningún tipo de práctica social o de movimiento susceptible de transformación de órdenes existentes. Esto último es precisamente lo que sucede con el ecologismo.

En base a las reflexiones sobre los imaginarios sociales elaboradas por Pintos (1994; 2000) y Manuel A. Baeza (2000), podemos señalar que una sociedad ecológica sería aquella en donde las ideas propuestas por el ecologismo se convierten en una matriz de sentido existencial colectivo que permite percibir y explicar la realidad y, sobre todo, lleva a intervenirla. El ecologismo sería una gran lente a través de la cual la sociedad se mira a sí misma y al mundo.

La realidad es construida socialmente desde determinadas perspectivas (distinciones), estas referencias (lo que es relevante y lo que no lo es) son emitidas por las instituciones que se disputan el poder (iglesias, gobiernos, grupos empresariales y políticos, movimientos sociales). Un imaginario se recrea cuando las distinciones que plantea son asumidas por un individuo como reales. Los imaginarios se expresan a través de símbolos -que pueden ser imágenes de personas o figuras de objetos y animales - y son transmitidos en nuestros días a través de los medios de comunicación ${ }^{13}$ (periódicos, revistas, cómics, productoras cinematográficas, televisoras, estaciones de radio..., donde la publicidad juega un papel central) y obras de arte (escultura, pintura, literatura, arquitectura).

No es suficiente difundir o inculcar a través de programas educativos los valores del ecologismo, se requiere crear un universo simbólico que permita su asimilación. Este universo simbólico debe ser mediatizado. Actualmente el imaginario de los habitantes de las zonas urbanas es conformado por conceptos de éxito personal, conformismo y libertad (individualismo, hed onismo, indiferencia, superficialidad) impuestos por el mercado, la identidad se construye a partir del consumo. Una sociedad ecológica debe fundarse a partir de la ideación colectiva de los conceptos de solidaridad, justicia social y frugalidad. Estos conceptos ya son manejados de una u otra manera por los diversos credos religiosos. Se puede argumentar que las religiones han perdido poder movilizador, ciertamente lo religioso es vinculado en nuestro tiempo con la perpetuación de jerarquías y dogmas metafísicos pasando a un segundo plano las diversas formas que ha desarrollado para fortalecer lo espiritual y comunitario -aspectos presentes en el pensamiento ecosocial-, pero en casi todos los países más del 80 por ciento de la población tiene algún tipo de creencia religiosa, esa necesidad de religión es la que debe explorarse. Por otra parte, a pesar de la globalización las identidades nacionales, regionales y locales no se han disuelto, al contrario, tienden a fortalecerse. El ecologismo debe conectarse asimismo con los imaginarios de carácter geográfico, de hecho encuentra en ellos algunas coincidencias: valorizan el sentido de lugar y movilizan por factores no consumistas. Baeza precisa que la ideología permanece en su calidad de simple retórica si no se conecta con los imaginarios existentes (Baeza, 2000: 30).

\footnotetext{
${ }^{13}$ Denominados por Pintos como 'empresas de construcción de realidades'.
} 
Una de las funciones de los imaginarios es ofrecer certidumbre. El desafío que se impone al ecologismo es brindar algún tipo de certeza para que las sociedades puedan adquirir cierto orden y destino: contar un cuento que la gente se quiera contar. El ecologismo ha sido problematizado a nivel periodístico y educativo generando alarma y un cúmulo de conocimientos, pero no un sentido. La degradación ambiental y la posibilidad de crear una sociedad ecológica, en otras palabras, el sentido de la sostenibilidad, no ha sido construido socialmente. Cada individuo debe comprender su impacto en la biosfera; al ser este impacto, dada la urbanización, de manera indirecta, es decir, el sujeto 'no ve' el daño que ocasiona ya que se limita a consumir y producir residuos a decenas, cientos o miles de kilómetros de los ecosistemas y biorregiones que son afectados -consecuencia de pautas impuestas mediáticamente por el mercado-, la significación de su huella ecológica y de su capacidad para disminuirla cruzan por la exposición a través de los medios de modelos que problematicen su actual modo de vida y esquema mental (personalidad consumista) y muestren tipos culturales alternativos (personalidad ecológica) acordes a las diversas realidades económicas y sociales y los límites ecológicos y energéticos gloables y de cada biorregión; tipos de personalidad construidos no a partir del mercado sino de la capacidad regenerativa de la biosfera y creativa de la especie humana. Cabe mencionar que las Naciones Unidas en la Agenda 21 (parágrafo 31.10b) recomiendan establecer y fortalecer grupos nacionales de asesoramiento sobre ética ecológica y del desarrollo, "a fin de crear un marco de valores común para la comunidad dedicada a la ciencia y la tecnología y toda la sociedad". El imaginario que se esboza se basa en el bien común, no en el consumo individual.

Indica Baeza:

Me parece que uno de los fenómenos más nítidos de influencia de los imaginarios sociales en el actuar es aquél de la utopía (que definiré como prefiguración hic et nunc de un mundo alternativo y futuro respecto al mundo vivido y presente). Las personas animadas de un pensamiento utópico llevan hasta las últimas consecuencias -en la elaboración imaginaria- la construcción de un nuevo mundo, construcción que podrá ser tildada de fantasmagórica por los escépticos, de quimera sin destino. Se suele, no obstante, distinguir entre utopías realizables (cuando se busca la obtención de medios adecuados para su concretización futura) y utopías irrealizables (cuando no se buscan dichos medios). En todo caso, atendiendo el frenesí con el cual los hombres se precipitan a una presunta domesticación del tiempo futuro (por vías diferentes), lo que me parece más difícilmente defendible es que las sociedades se despojen totalmente de la modalidad de pensamiento utópico (Baeza, 2000: 9 y 10).

El ecologismo es sin duda un pensamiento utópico realizable: existen ya experiencias y proyectos en materia energética, económica, agrícola, pesquera, ganadera, de organización social y productiva orientados por la eco-lógica. Dadas las condiciones ambientales, sociales e incluso económicas prevalecientes en el mundo se dibuja no como una alternativa sino como el modelo que debe adoptarse. Pero así como el ecologismo señala los límites del sistema capitalista el pensamiento crítico debe señalar los límites del ecologismo, específicamente, el riesgo de que se convierta en un sistema antidemocrático. El éxito de una sociedad ecológica depende en parte de que no sea impuesta de manera autoritaria, por esta razón las medidas regulativas en favor de la protección ambiental (impuestos, multas) en vez de fomentar una actitud ecológica estimulan el rechazo hacia todo lo relacionado con propuestas ecologizadoras. El ecologismo debe difundirse demostrando los beneficios económicos y sociales que puede producir -en algunas ciudades y regiones ya hay proyectos concretos.

La posmodernidad ha sido una época caracterizada por la inmovilidad en materia de construcción teórica de proyectos sociales. La justificada crítica hacia los metarrelatos clausuró la reflexión orientada hacia la búsqueda del bien común: pensar y hablar en nombre de 'la humanidad' suena sospechoso. Pero la deconstrucción del pensamiento cuyo objetivo es la creación de modelos sociales alternativos debe verse como un aspecto positivo ya que este ejercicio crítico permite, al señalar sus supuestos y puntos ciegos, esbozar modelos civilizadores más incluyentes y 
sostenibles. En este caso la posmodernidad aportaría elementos para construir la sociedad ecológica.

Desafortunadamente, el escepticismo posmoderno ha sido utilizado por el mercado para difundir un tipo de sociedad de acuerdo a sus fines, pero el 'todo vale' que ha favorecido el individualismo y el consumismo es ecológica y socialmente insostenible. Así como Gardner y Lewis indican que el relativismo cultural encuentra límites en el tema de género y la pobreza, el problema ambiental y la sostenibilidad invitan a pensar la dinámica societal a partir de la capacidad de resiliencia de las biorregiones, es decir, de los límites biofísicos y sociales y no de la maximización del consumo disfrazada de libertad. De modelos económicos orientados 'hacia fuera' desconocedores de los procesos que sustentan la vida debemos transitar a modelos económicos orientados 'hacia dentro' (endógenos) que internalicen y se construyan a partir de estos procesos.

La participación social está en función de los imaginarios compartidos, son estos los que movilizan a la gente para intervenir (transformar) la realidad: más que una convocatoria masiva se requiere un proyecto socialmente anhelado, una utopía, la visualización de una realidad diferente posible. Es aquí cuando el sujeto se convierte en actor, citando a Ulrich Beck, regresa a la sociedad: las iniciativas ciudadanas son las que definen actualmente los temas del futuro (reinvención de la político); el ecologismo ha ganado espacios precisamente por esta acción es necesario destacar el papel de los hombres y las mujeres de ciencia que han dejado su 'neutralidad' científica para gestionar la sostenibilidad-. Por esto es fundamental concentrarse en la manera como los individuos (las sociedades) construyen su 'realidad' (qué es problematizado, qué es denominado relevante, qué es calificado de interés público, qué debe ser regulado o administrado por el Estado, etc.) y cómo estas 'realidades' surgen de instituciones y grupos específicos con intereses específicos. La influencia de los medios en este proceso es fundamental, por eso deben democratizarse; esta propuesta no es nueva: la realizó Hans Magnus Enzensberger en $1970^{14}$. Sin embargo, la crítica a la mediatización y al consumismo ha sido ignorada por las Naciones Unidas: las estrategias culturales planteadas no se estructuran en torno a esto.

Bajo la perspectiva que hemos intentado presentar en este trabajo la gestión del desarrollo sostenible de los asentamientos humanos debe, junto a las diversas medidas de carácter tecnológico, financiero, normativo y educativo propuestas por el UNEP y el UNCHS, transmitir a través de los medios de comunicación modelos conectados con los imaginarios religiosos e identitarios existentes en cada nación, región y localidad que permitan a la gente visualizar el tipo de sociedad propuesta por el ecologismo -sus beneficios a corto y largo plazo-. No existe el imaginario (la utopía) que movilice a la gente en favor de la sostenibilidad: se requieren imágenes, metáforas, relatos, espacios urbanos, símbolos, etc., que introduzcan en las sociedades el proyecto ecológico como posibilidad. Por concentrarse en el mundo natural el ecologismo ha descuidado el mundo de las ideas (la cultura); ha profundizado en lo técnico, no en lo simbólico. Pero la utopía ecológica debe considerar el proceso de urbanización que experimenta la humanidad. Los símbolos existentes relacionados con el ecologismo están inspirados en culturas indígenas o campesinas premodernas, no reflejan la cotidianidad del sujeto urbano posmoderno, como ejemplo podemos citar el discurso adjudicado al Jefe Seattle ${ }^{15}$ (Anexo 3).

La creación de un universo simbólico que dé sentido al proyecto ambiental debe elaborarse asumiendo que el 'texto' que lee el sujeto urbano en su vida diaria está conformado por estructuras, artefactos, máquinas, edificios, anuncios, carteles, fotografías, pantallas... no por la naturaleza (los árboles y las plantas en las ciudades son ornamento), la cual es significada estética o terapéuticamente, no en su complejidad de sistema sustentador de la vida. Si antes la mayoría de los seres humanos interactuaban en su cotidianidad con los elementos, plantas y

\footnotetext{
14 "Constituents of a theory of the media" (New Left Review, No. 64, noviembre-diciembre 1970).

15 El autor del discurso fue el guionista de la película que lo popularizó: Ted Perry (Home, 1972). Seattle fue jefe de los indios suquamish y duwamish, tribus asentadas hasta mediados del siglo XIX en el territorio que actualmente corresponde al estado de Washington, Estados Unidos. Más información: http://www.snopes.com/quotes/seattle.htm.
} 
animales, ahora los medios condicionan de una u otra forma su existencia. Los ciclos que ocurren en la biosfera, de los cuales las sociedades dependen, no son percibidos por los habitantes de las zonas urbanas: ¿cómo significar el agotamiento del agua y los suelos cuando se compra agua embotellada y comida enlatada y empaquetada y se reciben mensajes que invitan a perpetuar un sistema económico y cultural basado en la sobreexplotación de los mantos acuíferos y los suelos? ¿Cómo significar la huella ecológica cuando su impacto no es experimentado directamente?

De un discurso en pro de la sostenibilidad naturalista centrado en proteger la biodiversidad y desarrollar tecnología no contaminante y energéticamente eficiente, pasamos a una perspectiva culturalista en donde los imaginarios sociales es el aspecto que debe ser analizado para favorecer la conservación y el ecodesarrollo. El problema ambiental había sido discutido sin profundizar en la dimensión ideológica -las ideologías habían muerto-. Pero al explorar el papel que ocupan los imaginarios en la determinación de lo socialmente deseable, el peso de las creencias e ideas compartidas por la gente evidencia el trasfondo ideológico de la relación de los seres humanos con el ambiente (urbano, rural y natural), cómo lo constituyen. La protección y restauración de ecosistemas y el desarrollo de ecotecnologías, ecoindustrias y ecogobiernos -y ecomedios- y la adopción de modos de vida posconsumistas será producto de decisiones aprobadas colectivamente, consideradas por la sociedad como convenientes.

La reflexión sobre la sostenibilidad debe explorar la conformación de la cultura: la forma como las ideas circulan dándole sentido a las sociedades. Circulación que acontece en nuestros días principalmente a través de los medios de comu-nicación. Hoy la mediatización favorece el desarrollo de una personalidad no ecológica (insostenible). La gestión de asentamientos humanos sostenibles debe modificar este proceso.

\section{Corolario}

La revolución tecnocomunicacional multiplica la circulación de información que facilita la gestión de la sostenibilidad... y las formas de evasión. Es un problema de conocimiento y de sentido: anhelos, opciones de existencia, tiempo y atención, arraigo y desarraigo. Los medios acercan el mundo lejano y alejan el mundo cercano: se piensa más en viajar a lugares paradisíacos que en habilitar y habitar el barrio, la ciudad y la biorregión donde se reside, ir al paraíso, no construirlo; o, en todo caso, adquirir un 'algo' para escapar, sin desplazarse, de lo cotidiano. Los medios, en este caso, no son una herramienta para la gestión de la sostenibilidad. Esto también debe ser agendado.

El lenguaje del imaginario es múltiple. Circula por todas partes en nuestras ciudades. Habla a la muchedumbre y ella le habla. Es el nuestro, el aire artificial que respiramos, el elemento urbano en el cual tenemos que pensar.

Michel de Certeau 


\section{Bibliografía}

ALLEMAND, S. 1999. "Développement durable et sciences sociales". En Sciences humaines. No. 92: $12-17$.

APALATEGUI, J. 1999. "Las principales teorías sociológicas sobre los movimientos sociales", en La anticipación de la sociedad. Psicología social de los movimientos sociales. Editado por J. Apalategui, pp. 101-139. Valencia: Promolibro.

ARIZPE, L. 1998. "La cultura como contexto del desarrollo". En El desarrollo económico y social en los umbrales del siglo XXI. Compilado por L. Emmerij y J. Núñez, pp. 191-197. Washington: Banco Interamericano de Desarrollo.

ARNOLD, M. 1999. "Ambiente y sociedad. La pérdida de la racionalidad global en las sociedades funcionalmente diferenciadas". Universidad de Chile.

http://rehue.csociales.cl/personales/marnold/mac03.htm

ARRIARAN, S 1997. Filosofía de la posmodernidad. Crítica a la modernidad desde América Latina. Ciudad de México: UNAM.

ARVON, H. (1980) 1982. La autogestión. Ciudad de México: Fondo de Cultura Económica.

BAEZA, M. 2000. Los caminos invisibles de la realidad social. Ensayo de sociología profunda sobre los imaginarios sociales. Santiago: RIL Ediciones/Ediciones Sociedad Hoy.

BARCENA, A. 2000. "Ciudadanía ambiental". En Participación, superación de la pobreza y desarrollo sustentable. Aprendizajes de los fondos sociales y ambientales de América Latina y el Caribe Editado por R. Quiroga, pp. 96-101. Santiago: Fondo de las Américas/FOSIS.

BATESON, G. (Editado por R. E. Donaldson). (1991) 1999. Una unidad sagrada. Pasos ulteriores hacia una ecología de la mente. Barcelona: Gedisa.

BAUDRILLARD, J. (1972) 1999. Crítica de la economía política del signo. Ciudad de México: Siglo Veintiuno Editores.

BECK, U. (1993) 1999. La invención de lo político. Buenos Aires: Fondo de Cultura Económica.

BEDOYA, E. y S. MARTINEZ. 2000. "De la economía ecológica a la ecología política: Balance global del ecomarxismo y la crítica al desarrollo". En Antropología del desarrollo. Teorías y estudios etnográficos en América Latina. Editado por A. Viola, pp. 129-167. Barcelona: Paidós.

BERGER, P. y T. LUCKMANN (1968) 1999. La construcción social de la realidad. Buenos Aires: Amorrortu Editores.

BERMAN, M. (1982) 1998. Todo lo sólido se desvanece en el aire. La experiencia de la modernidad. Ciudad de México: Siglo Veintiuno Editores.

BOOKCHIN, M. 1993. "What is social ecology?". En Environmental Philosophy: From animal rights to radical ecology. Editado por M. E. Zimmerman, pp. 436-454. Englewood Cliffs: Prentice Hall.

BOOKCHIN, M. 1992. Urbanization without cities: The rise and decline of citizenship. Montreal: Black Rose Books.

BOOKCHIN, M. 1978. Por una sociedad ecológica Barcelona: Gustavo Gili.

BORJA, J. y M. CASTELLS. 1997. Local y global. La gestión de las ciudades en la era de la información. Madrid: Taurus/UNCHS.

BOURDIEU, P. (1987) 1996. Cosas dichas. Barcelona: Gedisa.

BOZZOLI, M. E. 2000. "Malinowski Award Lecture. A role for anthropology in sustainable development in Costa Rica". En Human Organization. Vol. 59, No. 3: 275-279.

CARO, I. 1994. "La inseguridad urbana. Expresiones y causas". En El desarrollo social. Tarea de todos. Compilado por C. Contreras, pp. 129-151. Santiago: Comisión Sudamericana de Paz, Seguridad y Democracia.

CECEÑA, A. E. y A. BARREDA. 1995. Producción estratégica y hegemonía mundial. Ciudad de México: Siglo Veintiuno Editores.

CELECIA, J. 1998. "Desarrollo sostenible y ciudad: más allá del virtuoso discurso". En Ciudades. No. 37: $12-25$.

CHEATER, A. 1989. Social anthropology: an alternative introduction. Londres: Unwin Hyman.

CHOMSKY, N. y H. DIETERICH. 1995. La sociedad global. Educación, mercado y democracia. Ciudad de México: Joaquín Mortiz.

CORCUFF, P. (1995) 1998. Las nuevas sociologías. Madrid: Alianza Editorial.

COULOMB, R., J. ESCANDON y G. SANDOVAL. (1991) 1992. "Los desafíos medioambientales del poblamiento y de la urbanización. Por un hábitat y un desarrollo sostenible para todos, desde 
ahora y de cara al futuro". En ¿Un futuro común? Poblamiento, desarrollo y medio ambiente. Coordinado por E. Ortiz, pp. 99-114. Ciudad de México: Habitat International Coalition.

DALY, H. E. y J. B. COBB, JR. (1989) 1993. Para el bien común. Reorientando la economía hacia la comunidad, el ambiente y un futuro sostenible. Ciudad de México: Fondo de Cultura Económica. DAVIDSON-HUNT, I. J. y F. BERKES. 2000. "Environment and society through the lens of resilience: Toward a human-in-ecosystem perspective". University of Manitoba. http://129.79.82.45/IASCP/Papers/davidson_hunti041500.pdf

DE CERTEAU, M. (1974) 1999. La cultura en plural. Buenos Aires: Nueva Visión.

DE FLEUR, M. y S. BALL-ROKEACH. 1994. Teorías de la comunicación de masas. Ciudad de México: Paidós.

DE LUQUE, S. 2000. "El objeto de estudio en las ciencias sociales". En La posciencia. El conocimiento científico en las postrimerías de la modernidad. Editado por E. Díaz, pp. 221-243. Buenos Aires: Editorial Biblos.

DELGADO, J. M. y J. GUTIERREZ. 1995. "Socioanálisis cibernético. Una teoría de la autoorganización social". En Métodos y técnicas cualitativas de investigación en ciencias sociales. Editado por J. M. Delgado y J. Gutiérrez, pp. 581-603. Madrid: Editorial Síntesis.

DIAZ, E. 2000a. "El conocimiento como tecnología de poder". En La posciencia. El conocimiento científico en las postrimerías de la modernidad. Editado por E. Díaz, pp. 15-36. Buenos Aires: Editorial Biblos.

DIAZ, E. 2000b. "La ciencia después de la ciencia". En La posciencia. El conocimiento científico en las postrimerías de la modernidad. Editado por E. Díaz, pp. 383-397. Buenos Aires: Editorial Biblos.

DIAZ, E. 1999. Posmodernidad. Buenos Aires: Editorial Biblos.

DICKEY, S. 1997. "La antropología y sus contribuciones al estudio de los medios de comunicación". En Revista Internacional de Ciencias Sociales. No. 153.

http://www.unesco.org/issj/rics153/titlepage153.html

DOGAN, M. 1997. "Las nuevas ciencias sociales: grietas en las murallas de las disciplinas". En Revista Internacional de Ciencias Sociales. No. 153.

http://www.unesco.org/issj/rics153/titlepage153.html

ELGUIN, D. 1994. "Building a sustainable species-civilization: A challenge of culture and consciousness". En Futures. No. 26 (2): 234-245.

ELIZALDE, A. y R. QUIROGA. 2000. "Desarrollo y sustentabilidad". En Participación, superación de la pobreza y desarrollo sustentable. Aprendizajes de los fondos sociales y ambientales de América Latina y el Caribe. Editado por R. Quiroga, pp. 47-56. Santiago: Fondo de las Américas/FOSIS.

EMMERIJ, L. 1998. "Teoría y práctica del desarrollo: ensayo introductorio y conclusiones de política". En El desarrollo económico y social en los umbrales del siglo XXI. Compilado por L. Emmerij y J. Núñez, pp. 3-40. Washington: Banco Interamericano de Desarrollo.

ESCOBAR, A. 2000. "El lugar de la naturaleza y la naturaleza del lugar: globalización o posdesarrollo". En Antropología del desarrollo. Teorías y estudios etnográficos en América Latina. Editado por A. Viola, pp. 169-216. Barcelona: Paidós.

ESCOBAR, A. 1997. "Antropología y desarrollo". En Revista Internacional de Ciencias Sociales. No. 154. http://www.unesco.org/issj/rics154/titlepage154.html

ESTEVA, C. 1993. Cultura, sociedad y personalidad. Barcelona: Anthropos.

ESTEVA, G. (1992) 2000. "Desarrollo". En Antropología del desarrollo. Teorías y estudios etnográficos en América Latina. Editado por A. Viola, pp. 67-101. Barcelona: Paidós.

FALETTO, E. 2000. "Democracia, estilos de desarrollo y desarrollo sustentable". En Participación, superación de la pobreza y desarrollo sustentable. Aprendizajes de los fondos sociales y ambientales de América Latina y el Caribe. Editado por R. Quiroga, pp. 57-61. Santiago: Fondo de las Américas/FOSIS.

FECE, J. L. 2000. "Lectura crítica de medios audiovisuales". En Comunicación y educación en la sociedad de la información. Nuevos lenguajes y conciencia crítica Compilado por J. M. Pérez, pp. 135-168. Barcelona: Paidós.

FERNANDEZ, R. 1994. "Problemáticas ambientales y procesos sociales de producción del hábitat: territorio, sistemas de asentamiento, ciudades". En Ciencias sociales y formación ambiental. Editado por E. Leff, pp. 223-286. Barcelona: Gedisa/UNAM. 
FOLADORI, G. 1996. "Las fuerzas que guían el comportamiento humano con su ambiente". En Sociedad y medio ambiente: Constribuciones a la sociología ambiental en América Latina. Editado por A. López y P. Hernández, pp. 74-88. Ciudad de México: Asociación Latinoamericana de Sociología/Benemérita Univer-sidad Autónoma de Puebla/La Jornada Ediciones.

FREIRE, P. (1970) 1999. Pedagogía del oprimido. Ciudad de México: Siglo Veintiuno Editores.

FREIRE, P. (1969) 1997. La educación como práctica de la libertad. Ciudad de México: Siglo Veintiuno Editores.

FUNTOWICZ, S. y B. DE MARCHI. 2000. "Ciencia posnormal, complejidad reflexiva y sustentabilidad". En La complejidad ambiental. Coordinado por E. Leff, pp. 54-84. Ciudad de México: Siglo Veintiuno Editores/UNAM/UNEP.

GADOTTI, M. 2000. "Pedagogía de la Tierra y cultura de la sustentabilidad". Foro sobre nuestros retos globales. http://www.earthcharter.org/report/essays.htm.

GARCIA, F. 1995. "Análisis del sentido de la acción: el trasfondo de la intencionalidad". En Métodos y técnicas cualitativas de investigación en ciencias sociales. Editado por J. M. Delgado y J. Gutiérrez, pp. 493-527. Madrid: Editorial Síntesis.

GARCIA CANCLINI, N. 2000. "La épica de la globalización y el melodrama de la interculturalidad". En Nuevas Perspectivas desde/sobre América Latina: El desafío de los estudios culturales. Editado por M. Moraña, pp. 31-41. Santiago: Editorial Cuarto Propio/Instituto Internacional de Literatura Iberoamericana.

GARCIA CANCLINI, N. 1997. "Culturas urbanas de fin de siglo: La mirada antropológica". En Revista Internacional de Ciencias $\quad$ Sociales. 153. http://www.unesco.org/issj/rics153/titlepage153.html

GARDNER, K. y D. LEWIS. 1996. Anthropology, development and the post-modern challenge. Londres: Pluto Press

GEERTZ, C. (1983) 1994. Conocimiento local. Ensayos sobre la interpretación de las culturas. Barcelona: Paidós.

GEERTZ, C. (1973) 2000. La interpretación de las culturas. Barcelona: Gedisa.

GIARDINA, M. 2000. "El problema de la neutralidad en la ciencia y en la técnica". En La posciencia. El conocimiento científico en las postrimerías de la modernidad. Editado por E. Díaz, pp. 349-368. Buenos Aires: Editorial Biblos.

GODARD, F. 1998. "Algunos aspectos en juego en el futuro de nuestras ciudades". En Ciudades. No. 37: 36-43.

GONZALEZ, J. L. 2000. "Variables de la educación en comunicación". En Comunicación y educación en la sociedad de la información. Nuevos lenguajes y conciencia crítica Compilado por J. M. Pérez, pp. 171-220. Barcelona: Paidós.

GUDYNAS, E. y G. EVIA. 1991. La praxis por la vida: Introducción a las metodologías de la ecología social. Montevideo: CIPFE/CLAES/NORDAN.

GUIMARAES, R. 2000. "Participación y ética: Hacia un nuevo paradigma de desarrollo sustentable". En Participación, superación de la pobreza y desarrollo sustentable. Apren dizajes de los fondos sociales y ambientales de América Latina y el Caribe. Editado por R. Quiroga, pp. 7595. Santiago: Fondo de las Américas/FOSIS.

HERZFELD, M. 1997. "La antropologa: práctica de una teoría". En Revista Internacional de Ciencias Sociales. No. 153.

http://www.unesco.org/issj/rics153/titlepage153.html

HOPENHAYN, M. 1994. Ni apocalípticos ni integrados. Aventuras de la modernidad en América Latina. Santiago: Fondo de Cultura Económica.

HUBINGER, V. 1997. "Antropología y modernidad". En Revista Internacional de Ciencias Sociales. No. 154. http://www.unesco.org/issj/rics154/titlepage154.html

JAMESON, F. (1998) 1999. El Giro Cultural. Escritos seleccionados sobre el posmodernismo 1983-1998. Buenos Aires: Manantial.

JAVALOY, F., E. ESPELL y A. RODRIGUEZ. 1999. "El movimiento ecologista: ideología e identidad". En La Anticipación de la sociedad. Psicología social de los movimientos sociales. Editado por J. Apalategui, pp. 167-201. Valencia: Promolibro.

JOHNSON, W. (1978) 1981. La era de la frugalidad. Barcelona: Kairós. 
KLIKSBERG, B. 2000. "El capital social". En Participación, superación de la pobreza y desarrollo sustentable. Aprendizajes de los fondos sociales y ambientales de América Latina y el Caribe. Editado por R. Quiroga, pp. 113-131. Santiago: Fondo de las Américas/FOSIS.

KOTTAK, C. P. 1999. "The new ecological anthropology". En American Anthropologist 101 (1): 2335.

KOTTAK, C. P. (1996) 1997. Antropología cultural: Espejo para la humanidad. Madrid: McGrawHill.

KOTTAK, C. P. (1990) 2000. "La cultura y 'el desarrollo económico'". En Antropología del desarrollo. Teorías y estudios etnográficos en América Latina. Editado por A. Viola, pp. 103-126. Barcelona: Paidós.

LASSONDE, L. (1996) 1997. Los desafíos de la demografía. ¿Qué calidad de vida habrá en el siglo XXI? Ciudad de México: UNAM/Fondo de Cultura Económica.

LEFF, E. 2000. "Pensar la complejidad ambiental". En La complejidad ambiental. Coordinado por E. Leff, pp. 7-53. Ciudad de México: Siglo Veintiuno Editores/UNAM/UNEP.

LEFF, E. 1998. Saber ambiental: sustentabilidad, racionalidad, complejidad, poder. Ciudad de México: Siglo Veintiuno Editores/UNAM/UNEP.

LEFF, E. 1994. Ecología y capital. Racionalidad ambiental, democracia participativa y desarrollo sustentable. Ciudad de México: Siglo Veintiuno Editores/UNAM.

LEFF, E. 1994. "Sociología y ambiente: Formación socioeconómica, racionalidad ambiental y transformaciones del conocimiento". En Ciencias sociales y formación ambiental. Editado por E. Leff, pp. 17-84. Barcelona: Gedisa/UNAM.

LUZZI, D. 2000. "La 'ambientalización' de la educación formal. Un diálogo abierto en la complejidad del campo educativo". En La complejidad ambiental. Coordinado por E. Leff, pp. 158192. Ciudad de México: Siglo Veintiuno Editores/UNAM/UNEP.

MARTIN BARBERO, J. 2000. "Globalización y multiculturalidad: notas para una agenda de investigación". En Nuevas Perspectivas desde/sobre América Latina: El desafío de los estudios culturales. Editado por M. Moraña, pp. 17-29. Santiago: Editorial Cuarto Propio/Instituto Internacional de Literatura Iberoamericana.

MARTIN BARBERO, J. (1991) 1994. "Dinámicas urbanas de la cultura". En Comunicación y espacios culturales en América Latina. Editado por UNESCO, pp. 168-175. Bogotá: Pontificia Universidad Javeriana.

MARTINEZ, J. 1994. De la economía ecológica al ecologismo popular. Barcelona: Icaria.

MARTINEZ, U. 1990. Antropología económica. Conceptos, teorías, debates. Barcelona: Icaria.

MARTINIC, S. 1997. Diseño y evaluación de proyectos sociales. Conceptos y herramientas para el aprendizaje. Ciudad de México: Colectivo Mexicano de Apoyo a la Niñez/Centro Juvenil Promoción Integral.

MAX-NEEF, M., A. ELIZALDE y M. HOPENHAYN. 1993. Desarrollo a escala humana. Conceptos, aplicaciones y algunas reflexiones. Montevideo: Nordan-Comunidad/lcaria.

MELUCCI, A. 1998. "Acción colectiva y transformación personal en la era de la información". En Ciudades. No. 37: 3-11.

MILLER, G. T. (1992) 1994. Ecología y medio ambiente Ciudad de México: Grupo Editorial Iberoamericana.

MILTON, K. 1997. "Ecologías: antropología, cultura y entorno". En Revista Internacional de Ciencias Sociales. No. 154.

http://www.unesco.org/issj/rics154/titlepage154.html

MITLIN, D. y D. SATTERTHWAITE. (1991) 1992. "Desarrollo sustentable y ciudades. Un marco para discutir la relación entre las ciudades y el desarrollo sustentable". En ¿Un futuro común? Poblamiento, desarrollo y medio ambiente. Coordinado por E. Ortiz, pp. 49-98. Ciudad de México: Habitat International Coalition.

MOREIRAS, A. 2000. "Hegemonía y subalternidad". En Nuevas Perspectivas desde/sobre América Latina: El desafío de los estudios culturales. En M. Moraña, pp. 135-147. Santiago: Editorial Cuarto Propio/Instituto Internacional de Literatura Iberoamericana.

MORIN, E. 1993. Tierra-Patria. Barcelona: Kairós.

MORIN, E. (1990) 1997. Introducción al pensamiento complejo. Barcelona: Gedisa.

MOSCOSO, C. 2000. "Participación ciudadana y desarrollo sustentable". En Participación, superación de la pobreza y desarrollo sustentable. Aprendizajes de los fondos sociales y 
ambientales de América Latina y el Caribe. Editado por R. Quiroga, pp. 102-110. Santiago: Fondo de las Américas/FOSIS.

MOURA, I. 2000. "Los sentidos de lo 'ambiental': La contribución de la hermenéutica a la pedagogía de la complejidad". En La complejidad ambiental. Coordinado por E. Leff, pp. 85-105. Ciudad de México: Siglo Veintiuno Editores/UNAM/UNEP.

NAVARRO, P. 1996. "Hacia una teoría de la morfogénesis social". Universidad de Oviedo. http://www.netcom.es/pnavarro/home.html

NEIRA, E. (1991) 1992. "Medio ambiente y hábitat. Recursos, accesibilidad, tecnología, infraestructura". En ¿Un futuro común? Poblamiento, desarrollo y medio ambiente Coordinado por E. Ortiz, pp. 115-132. Ciudad de México: Habitat International Coalition.

NITZ, M. 1999. "The media as a tool for communication on environment and sustainability". The millennium conference on environmental education and communication. http://umweltprogramme.de/millennium/papers/paper7/

OECD. 1999. Environmental communication. Applying communication tools towards sustainable development. París: OECD.

OECD. 1997. The world in 2020. Towards a new global age. París: OECD.

ORTIZ, R. 2000. "Diversidad cultural y cosmopolitismo". En Nuevas Perspectivas desde/sobre América Latina: El desafío de los estudios culturales. En M. Moraña, pp. 43-54. Santiago: Editorial Cuarto Propio/Instituto Internacional de Literatura Iberoamericana.

ORTOLANI, V. 1984. Personalidad ecológica Puebla: Universidad Iberoameri-cana.

PAEZ, A. 2001. "Hacia una sociedad ecológica". En Formación Ambiental. Vol. 13, No. 28: 10-12. Ciudad de México: UNEP.

PAEZ, A. 2000. "Desarrollo humano, huella ecológica y exclusión: El regreso de la agricultura". En Revista electrónica del Magíster en Antropología y Desarrollo. No. 3. Universidad de Chile.

http://rehue.csociales.uchile.cl/publicaciones/mad/03/paper08.htm.

PAEZ, A. 1999. "Del desarrollo a la ecología social". Revista electrónica del Magíster en Antropología y Desarrollo. No. 1. Universidad de Chile.

http://rehue.csociales.uchile.cl/publicaciones/mad/ 01/paper01.htm

PAEZ, A. 1998. "Hacia un desarrollo endógeno". Inédito.

PARDO, R. H. 2000. "Verdad e historicidad. El conocimiento científico y sus fracturas". En La posciencia. El conocimiento científico en las postrimerías de la modernidad. Editado por E. Díaz, pp. 37-62. Buenos Aires: Editorial Biblos.

PEREZ, J. M. 2000a. "Las escuelas y la enseñanza en la sociedad de la información". En Comunicación y educación en la sociedad de la información. Nuevos lenguajes y conciencia crítica Compilado por J. M. Pérez, pp. 37-58. Barcelona: Paidós.

PEREZ, J. M. 2000b. "Los nuevos procesos de mediación: del texto al hipermedia". En Comunicación y educación en la sociedad de la información. Nuevos lenguajes y conciencia crítica Compilado por J. M. Pérez, pp. 73-84. Barcelona: Paidós.

PEREZ, J. M. 2000c. "La nueva competencia comunicativa en un contexto mediático". En Comunicación y educación en la sociedad de la información. Nuevos lenguajes y conciencia crítica Compilado por J. M. Pérez, pp. 85-103. Barcelona: Paidós.

PESCI, R. 2000. "La pedagogía de la cultura ambiental: Del Titanic al velero". En La complejidad ambiental. Coordinado por E. Leff, pp. 115-157. Ciudad de México: Siglo Veintiuno Editores/UNAM/UNEP.

PINTOS, J. L. 2000. "Construyendo realidad(es): Los imaginarios sociales". Universidad de Santiago de Compostela.

http://web.usc.es/ jlpintos/articulos/construyendo.htm

PINTOS, J. L. 1998. "Apuntes para una teoría: Los 'medios', la 'realidad' y la alternativa local". Universidad de Santiago de Compostela.

http://web.usc.es/ jlpintos/articulos/medios.htm

PINTOS, J. L. 1994. "Los imaginarios sociales (La nueva construcción de la realidad social)". Universidad de Santiago de Compostela.

http://web.usc.es/ jlpintos/articulos/imaginarios.htm

POLESE, M. (1994) 1995. "Desarrollo económico y urbanización". En Desarrollo regional y globalización económica. Compilado por S. Flores, pp. 129-152. Puebla: Universidad Autónoma de Tlaxcala/Benemérita Universidad Autónoma de Puebla. 
RABEY, M. y O. JEREZ. 2000. "La sustentabilidad está en la gente". Universidad Nacional de Jujuy. http://www.naya.org.ar/congreso2000/ponencias_xautor.htm

RAPPAPORT, R. A. (1971) 1975. "Naturaleza, cultura y antropología ecológica". En Hombre, cultura y sociedad. Editado por H. L. Shapiro, pp. 261-292. Ciudad de México: Fondo de Cultura Económica.

RAZETO, L. 1997. Los caminos de la economía de solidaridad. Buenos Aires: Lumen-Hvmanitas. RIVERA, S. 2000. "Ernesto Laclau: una nueva lógica de las relaciones sociales". En La posciencia. El conocimiento científico en las postrimerías de la modernidad. Editado por E. Díaz, pp. 329-345. Buenos Aires: Editorial Biblos.

ROBLES, F. 2000. El desaliento inesperado de la modernidad. Molestias, irritaciones y frutos amargos de la sociedad del riesgo. Santiago: Ediciones Sociedad Hoy/Universidad de Concepción/RIL Ediciones.

RODRIGUEZ, D. 1996. Gestión organizacional. Elementos para su estudio. Ciudad de México: Universidad Iberoamericana/Plaza y Valdés Editores.

RODRIGUEZ, D. y M. ARNOLD. 1990. Sociedad y teoría de sistemas. Santiago: Editorial Universitaria.

ROWE, W. y V. SCHELLING (1991) 1993. Memoria y modernidad. Cultura popular en América Latina. Ciudad de México: Consejo Nacional para la Cultura y las Artes/Grijalbo.

SABUCEDO, J. M., B. KLANDERMANS, M. RODRIGUEZ y M. DE WEERD. 1999. "Pertenencia a organizaciones y legitimación de la acción colectiva". En La anticipación de la sociedad. Psicología social de los movimientos sociales. Editado por J. Apalategui, pp. 141-164. Valencia: Promolibro. SACHS, I. 1982. Ecodesarrollo: Desarrollo sin destrucción. Ciudad de México: El Colegio de México.

SANTIBAÑEZ, C. 2000. "La televisión en la vida cotidiana: Elementos para comprender su importancia". En Revista electrónica del Magíster en Antropología y Desarrollo. No. 2. Universidad de Chile.

http://rehue.csociales.uchile.cl/publicaciones/mad/02/paper03.htm.

SARTORI, G. (1997) 1998. Homo videns. La sociedad teledirigida. Madrid: Taurus.

SCHUTZ, A. (1964) 1974. Estudios sobre teoría social. Buenos Aires: Amorrortu Editores.

SCHUTZ, A. (1962) 1995. El problema de la realidad social. Buenos Aires: Amorrortu Editores.

SEN, A. 1998. "Teoría del desarrollo a principios del siglo XXI". En El desarrollo económico y social en los umbrales del siglo XXI. Compilado por L. Emmerij y J. Núñez, pp. 589-610. Washington: Banco Interamericano de Desarrollo.

SIMONDS, J. O. 1978. Earthscape: A manual of environmental planning. Nueva York: Van Nostrand Reinhold.

SODRE, M. (1996) 1998. Reinventando la cultura Barcelona: Gedisa.

STEADMAN, P. (1975) 1978. Energía, medio ambiente y edificación. Madrid: H. Blume.

STEWARD, J. (1955) 1993. "El concepto y el método de la ecología cultural". En Antropología. Lecturas. Editado por P. Bohannan y M. Glazer, pp. 334-344. Madrid: McGraw -Hill.

STREETEN, P. 1998. "Globalización y competitividad: ¿cuáles son las implicaciones para la teoría y la práctica del desarrollo?". En El desarrollo económico y social en los umbrales del siglo XXI. Compilado por L. Emmerij y J. Núñez, pp. 118-162. Washington: Banco Interamericano de Desarrollo.

SUNKEL, O. 1994. "La crisis social en América Latina. Una perspectiva neoestructuralista". En El desarrollo social. Tarea de todos. Compilado por C. Contreras, pp. 27-93. Santiago: Comisión Sudamericana de Paz, Seguridad y Democracia.

TAINTER, J. 1996. "Complexity, problem solving and sustainable societies". En Getting down to Earth: Practical applications of ecological economics. Editado por R. Constanza, O. Segura y J. Martínez, pp. 61-76. Washington: Island Press.

TAINTER, J. 1988. The collapse of complex societies. Cambridge: Cambridge University Press.

THOMAS, N. 1997. "Epistemologías de la antropología". En Revista Internacional de Ciencias Sociales. No. 153.

http://www.unesco.org/issj/rics153/titlepage153.html

TOURAINE, A. (1996) 1997. ¿Podremos vivir juntos? Iguales y diferentes. Buenos Aires: Fondo de Cultura Económica. 
UNCHS. 2001. Declaration on cities and other human settlements in the new millenium. Nairobi: UNCHS.

http:// www.unchs.org/istanbul+5/declaration_cities.htm.

UNCHS. 1996a. Programa de Hábitat. Nairobi: UNCHS.

http://www.unchs.org/unchs/spanish/hagendas/

UNCHS. 1996b. Declaración de Estambul sobre los asentamientos humanos. Nairobi: UNCHS. http://www.unchs.org/unchs/spanish/hagendas/

UNCHS. 1976a. Action plan for human settlements. Nairobi: UNCHS.

http://www.undp.org/un/habitat/back/vp-intr.html

UNCHS. 1976b. The Vancouver declaration on human settlements.

Nairobi: UNCHS.

http://www.unchs.org/tenure/Legal/van_dec.htm

UNDP. 2001. Informe sobre desarrollo humano 2001. Poner el adelanto tecnológico al servicio del desarrollo humano. Nueva York: UNDP/Mundi-Prensa Libros.

UNEP. 2000a. Perspectivas del medio ambiente mundial 2000. Panorama general. Nueva York:

UNEP. http://www.unep.org/Geo2000/ov-es.pdf

UNEP. 2000b. Declaración de Malmö. Nueva York: UNEP.

http://www.rolac.unep.mx/Docamb/esp/ms2000.htm

UNEP. 1997. Programme for furher implementation of Agenda 21. Nueva York: UNEP.

http://www.un.org/documents/ga/res/spec/aress19-2.htm

UNEP. 1992a. Agenda 21. Nueva York: UNEP.

http://www.un.org/esa/sustdev/agenda21sp/

UNEP. 1992b. Declaración de Río sobre el Medio Ambiente y el Desarrollo. Nueva York: UNEP. http://www.un.org/esa/sustdev/agenda21sp/riodeclaration.htm

UNEP. 1972a. Plan de acción para el medio humano. Nueva York: UNEP.

http://www.conama.cl/gestion_ambiental/acuerdos_inter/estocolmo_B.htm

UNEP. 1972b. Declaración de Estocolmo sobre el medio humano. Nueva

York: UNEP.

http://www.conama.cl/gestion_ambiental/acuerdos_inter/estocolmo_B.htm

UNESCO. 2000. Informe mundial sobre la cultura. París: UNESCO.

UNESCO. 1997. Educación para un futuro sostenible: Una visión transdisciplinaria para una acción concertada. París: UNESCO.

VALENCIA, J., L. REIZABAL, L. GIL DE MONTES y E. SANSINENEA. 1999. "Movimientos sociales y paz". En La anticipación de la sociedad. Psicología social de los movimientos sociales. Editado por J. Apalategui, pp. 203-237. Valencia: Promolibro.

VAN DIJK, T. A. (1998) 1999. Ideología: Una aproximación multidisciplinaria. Barcelona: Gedisa.

VESSURI, H. B. 1994. "La formación en antropología ambiental a nivel universitario". En Ciencias sociales y formación ambiental. Editado por E. Leff, pp. 181-222. Barcelona: Gedisa/UNAM.

VILLASANTE, T. R. 1998a. Cuatro redes para mejor-vivir 1. Del desarrollo local a las redes para mejor-vivir. Buenos Aires: Lumen-Hvmanistas.

VILLASANTE, T. R. 1998b. Cuatro redes para mejor-vivir 2. De las redes sociales a las programaciones integrales. Buenos Aires: Lumen-Hvmanistas.

VIO, F. 1994. "La sociedad ecológica. Nuevos paradigmas, ecología y desarrollo". En El desarrollo social. Tarea de todos. Compilado por C. Contreras, pp. 239-257. Santiago: Comisión Sudamericana de Paz, Seguridad y Democracia.

VIOLA, A. 2000. "La crisis del desarrollismo y el surgimiento de la antropología del desarrollo". En Antropología del desarrollo. Teorías y estudios etnográficos en América Latina. Editado por A. Viola, pp. 9-64. Barcelona: Paidós.

WACKERNAGEL, M. y W. REES. 1996. Our ecological footprint. Reducing human impact on the Earth. Gabriola Island: The New Catalyst.

WILSON, P. 1996. "Empowerment: Community economic development from the inside out". En Urban Studies. Vol. 33, Nos. 4-5: 617-630. 